UNIVERSIDADE DE SÃO PAULO

FACULDADE DE ECONOMIA, ADMINISTRAÇÃO E CONTABILIDADE DEPARTAMENTO DE ADMINISTRAÇÃO

PROGRAMA DE MESTRADO PROFISSIONAL EM EMPREENDEDORISMO

INOVAÇÃO NO VAREJO: DIRETRIZES PARA IMPLEMENTAÇÃO DE ESTRATÉGIA DE GESTÃO DE CLIENTES EM AMBIENTE MULTICANAL

Eduardo Bonilha

Orientador: Prof. Dr. Edson Crescitelli 
Prof. Dr. Marco Antonio Zago

Reitor da Universidade de São Paulo

Prof. Dr. Adalberto Américo Fischmann

Diretor da Faculdade de Economia, Administração e Contabilidade

Prof. Dr. Roberto Sbragia

Chefe do Departamento de Administração

Prof. Dr. Martinho Isnard Ribeiro de Almeida

Coordenador do Programa de Mestrado Profissional em Empreendedorismo 


\title{
INOVAÇÃO NO VAREJO: DIRETRIZES PARA IMPLEMENTAÇÃO DE ESTRATÉGIA DE GESTÃO DE CLIENTES EM AMBIENTE MULTICANAL
}

\author{
Dissertação apresentada ao Departamento de \\ Administração da Faculdade de Economia, \\ Administração e Contabilidade da \\ Universidade de São Paulo, como requisito \\ parcial para obtenção do título de Mestre em \\ Ciências no Programa de Mestrado Profissional \\ em Empreendedorismo.
}

Orientador: Prof. Dr. Edson Crescitelli

\section{Versão Corrigida}

(versão original disponível na Biblioteca da Faculdade de Economia, Administração e Contabilidade)

\section{SÃO PAULO}




\section{FICHA CATALOGRÁFICA}

Elaborada pela Seção de Processamento Técnico do SBD/FEA/USP

Bonilha, Eduardo.

Inovação no varejo: diretrizes para implementação de estratégia de gestão de clientes em ambiente multicanal. - São Paulo, 2016. $106 \mathrm{p}$.

Dissertação (Mestrado) - Universidade de São Paulo, 2016. Orientador: Edson Crescitelli.

1. Varejo. 2. Varejo multicanal. 3. Gestão de clientes. 4. Marketing de relacionamento. 5. CRM- Customer relationship management. 6. Inovação empresarial. I. Universidade de São Paulo. Faculdade de Economia, Administração e Contabilidade. II. Título.

CDD 658.87 

À minha querida esposa Deise, meus filhos Maria Eduarda e Rafael, meus pais Carlos e Eliete, meus irmãos e sobrinhos, todo amor e gratidão pelo apoio em mais uma jornada. 


\section{AGRADECIMENTOS}

Agradeço a Deus, em primeiro lugar, e a todas as pessoas que participaram desta caminhada.

A todos os colaboradores da FEA-USP, do Programa de Pós-graduação em Administração e do Programa de Mestrado Profissional em Empreendedorismo, principalmente à Fabiana Caseiro, que deu toda a atenção e suporte necessários ao longo dos dois anos e meio de mestrado.

Ao meu orientador Prof. Dr. Edson Crescitelli pelo companheirismo, dedicação, ensinamentos e dicas preciosas para que este trabalho pudesse ser concluído.

Aos professores do Programa de Mestrado Profissional em Empreendedorismo, pela imensa contribuição à minha formação acadêmica, profissional e pessoal, representados pelo Prof. Dr. Martinho Isnard Ribeiro de Almeida, Prof. Dr. Marcelo Caldeira Pedroso e Prof. Dr. Fabio Lotti Oliva, que não mediram esforços para o desenvolvimento e sucesso deste curso pioneiro.

Aos meus estimados colegas da primeira turma do Programa de Mestrado Profissional em Empreendedorismo da FEA-USP, pelos conhecimentos compartilhados, trabalho em conjunto, apoio mútuo, amizade e momentos agradáveis que passamos juntos.

Aos consultores e executivos que se dispuseram a participar desta pesquisa, disponibilizando seu tempo, conhecimentos, experiências e impressões sobre os temas abordados.

Em especial, à minha família, minha esposa Deise, meus filhos Maria Eduarda e Rafael, meus pais Carlos e Eliete, e meus irmãos Júnior, Marcelo e Rodrigo, pela compreensão, carinho e amor incondicional em cada passo da minha trajetória.

Muito obrigado! 
"Sua empresa pode criar mais produtos, mas não pode criar mais clientes."

Don Peppers e Martha Rogers

"Os resultados são obtidos através da exploração de oportunidades, não pela solução de problemas."

Peter Drucker 


\section{RESUMO}

O setor de varejo brasileiro passa por um grande processo de transformação, em ambiente de alta competição e forte tendência de atuação multicanal, com surgimento de novas tecnologias e observação de mudanças no comportamento dos consumidores. Diante deste cenário, existe oportunidade para criar diferenciais competitivos por meio de estratégia de gestão de clientes, assim como já ocorre em outros setores. O objetivo deste estudo é identificar e analisar as diretrizes para implementação dos principais processos da estratégia de gestão de clientes em organizações de varejo em ambiente multicanal, de qualquer segmento de atuação, bem como entender desafios, restrições, oportunidades e outros aspectos relevantes. Após relato da experiência profissional do autor em projetos de gestão de clientes, em especial nos setores de serviços e varejo, buscou-se na teoria os principais temas relacionados - Varejo Multicanal, Consumidor Omnichannel e Gestão de Clientes - para posterior análise, comparação com a prática e direcionamento da pesquisa empírica. Como método de pesquisa, escolheu-se a abordagem exploratória e qualitativa, por meio de entrevista pessoal em profundidade com 13 especialistas em varejo e gestão de clientes, utilizando roteiro semiestruturado. Para avaliação das respostas obtidas, foram considerados os procedimentos de análise de conteúdo, que resultaram em 7 categorias temáticas: i) cenário competitivo do varejo brasileiro; ii) mudanças no comportamento dos consumidores; iii) características e integração do varejo multicanal; iv) processo de desenvolvimento da estratégia de clientes; v) processo de gestão da informação / conhecimento dos clientes; vi) processo de criação de valor / experiência dos clientes; vii) processo de avaliação de desempenho e resultados. À luz da experiência relatada e referencial teórico, as diretrizes para implementação da estratégia de gestão de clientes foram analisadas e consolidadas, alcançando os objetivos propostos e contribuindo para a prática em organizações de varejo multicanal, bem como para a inovação de marketing e organizacional. Como contribuição para a teoria, a pesquisa abordou alguns temas e conceitos ainda pouco explorados na literatura acadêmica, abrindo também espaço para o desenvolvimento de novos estudos.

Palavras-chave: Varejo, Varejo multicanal, Gestão de clientes, Marketing de relacionamento, CRM - Customer relationship management, Inovação empresarial. 


\begin{abstract}
Brazilian retail sector undergo a considerable transformation process, in high competition environment and strong trend of multichannel operation, with emergence of new technologies and changes in consumers behavior. In this scenario, there is opportunity to create competitive advantages through customer management strategy, as already in other sectors. The aim of this study is to identify and analyze the guidelines for implementation of the main processes of customer management strategy in retail organizations in multichannel environment, in any business segment, as well as understand the challenges, constraints, opportunities, and other relevant aspects. After reporting author's professional experience in customer management projects, especially in services and retail, it was researched in theory the main issues Multichannel Retail, Omnichannel Consumer and Customer Management - for later analysis, comparation to practice and direction of empirical research. As a research method was chosen exploratory and qualitative approach, through personal in-depth interviews with 13 specialists in retail and customer management, using semi-structured script. For evaluation of the obtained responses, content analysis procedures were considered, which resulted in seven thematic categories: i) competitive landscape of the Brazilian retail sector; ii) changes in consumers behavior; iii) characteristics and integration of multichannel retail; iv) customer strategy development process; v) information management process / customer knowledge; vi) creating value process / customer experience; vii) performance evaluation and results process. In light of the reported experience and theoretical reference, guidelines for implementation of customer management strategy were analyzed and consolidated, achieving the proposed goals and contributing to the practice in multichannel retail organizations, as well for marketing and organizational innovation. As a contribution to the theory, this research addressed some issues and concepts still few explored in academic literature, also making room for the development of new studies.
\end{abstract}

Keywords: Retail, Multichannel retail, Customer management, Relationship marketing, CRM - Customer relationship management, Business innovation. 


\section{SUMÁRIO}

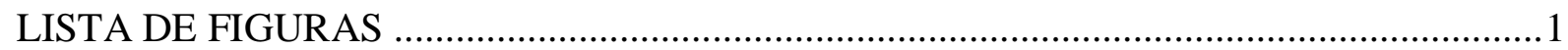

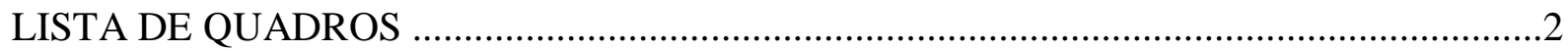

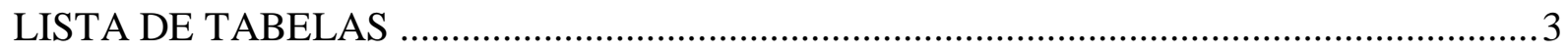

1. INTRODUÇÃ

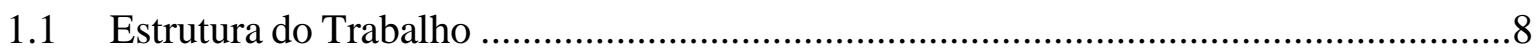

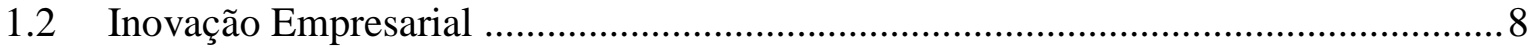

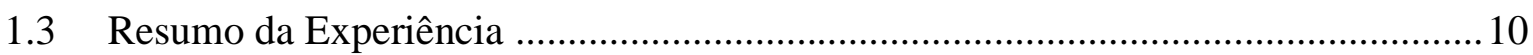

1.4 Problemática e Questão de Pesquisa ................................................................... 11

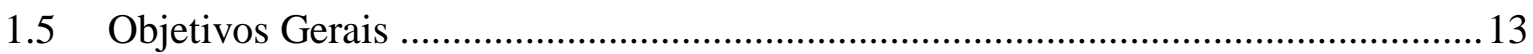

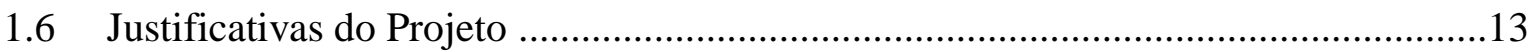

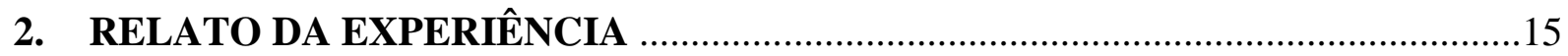

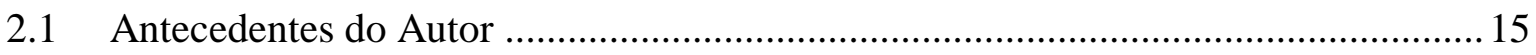

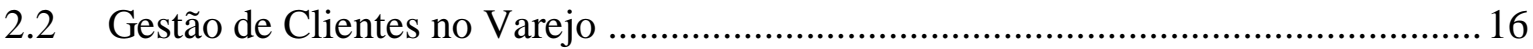

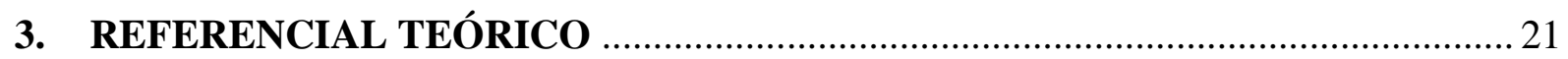

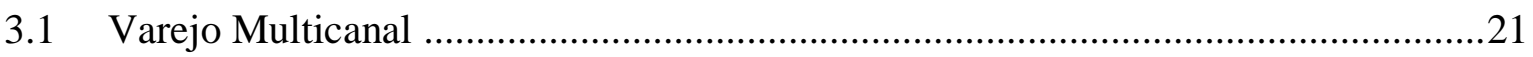

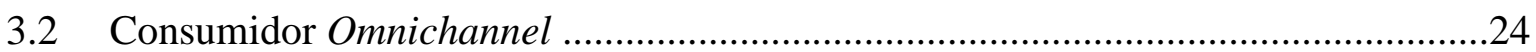

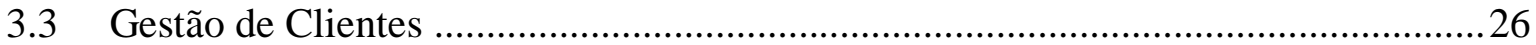

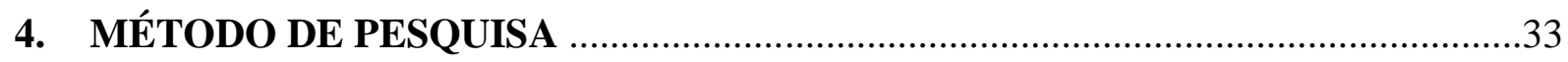

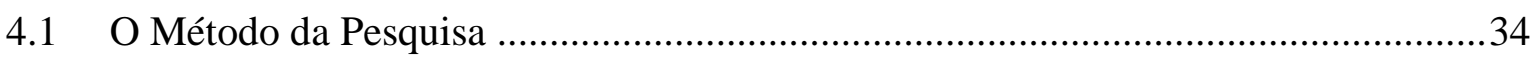

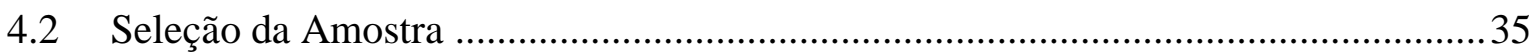

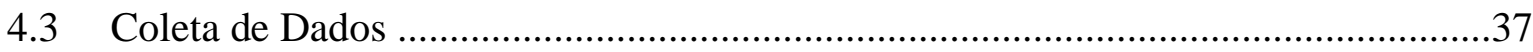

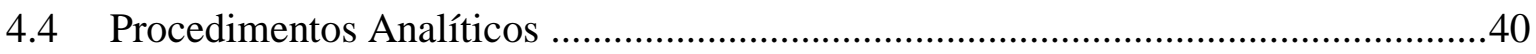

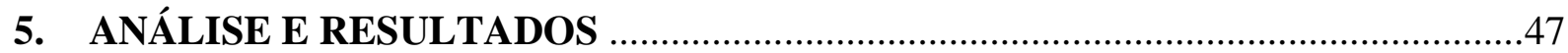

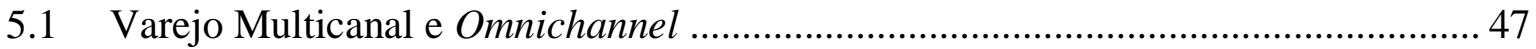

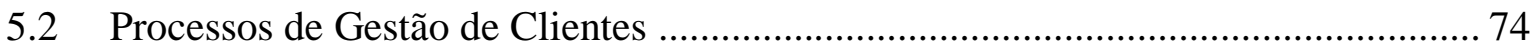

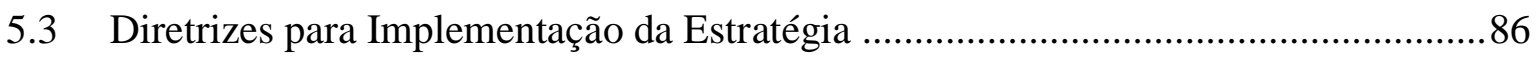

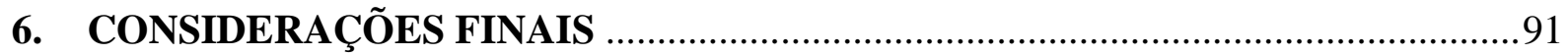

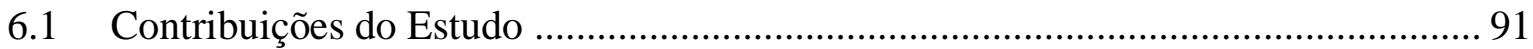

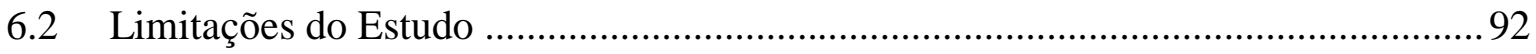

6.3 Recomendações de Pesquisas Futuras ...................................................................93

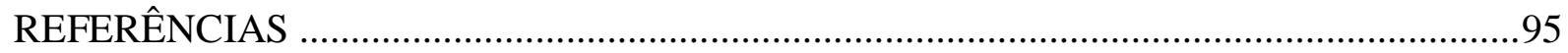

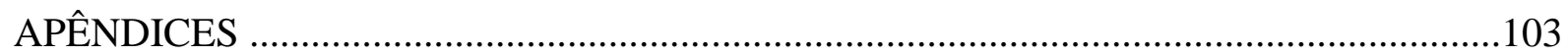

Apêndice A - Roteiro de Entrevista em Profundidade ..........................................................103

Apêndice B - Fichas com Descrição dos Temas de Pesquisa ............................................... 106 



\section{LISTA DE FIGURAS}

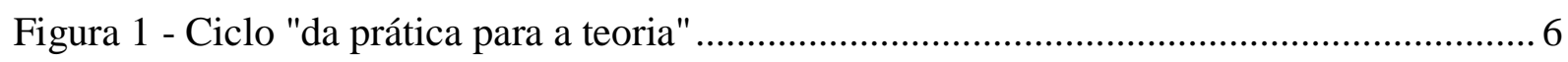

Figura 2 - Estrutura do trabalho de mestrado profissional ................................................... 7

Figura 3 - Fatores ambientais que impactam a gestão de clientes no varejo........................... 12

Figura 4 - Visão da estratégia de gestão de clientes no varejo................................................ 18

Figura 5 - Relação entre relato da experiência e referencial teórico ....................................... 21

Figura 6 - Desenvolvimento de análise de conteúdo............................................................ 41

Figura 7 - Consolidação das diretrizes para implementação de gestão de clientes ..................90 


\section{LISTA DE QUADROS}

Quadro 1 - Informações dos especialistas entrevistados .................................................... 37

Quadro 2 - Categorias e temas de Varejo Multicanal e Omnichannel ..................................... 38

Quadro 3 - Categorias e temas de Processos de Gestão de Clientes ........................................ 39

Quadro 4 - Sistemas de categorias de Varejo Multicanal e Omnichannel .............................. 44

Quadro 5 - Sistemas de categorias de Processos de Gestão de Clientes ................................. 45 


\section{LISTA DE TABELAS}

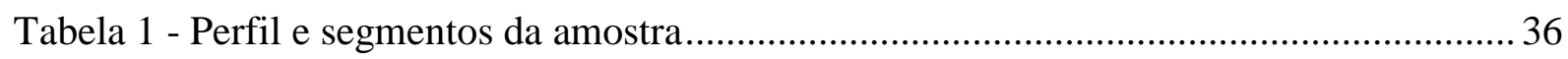

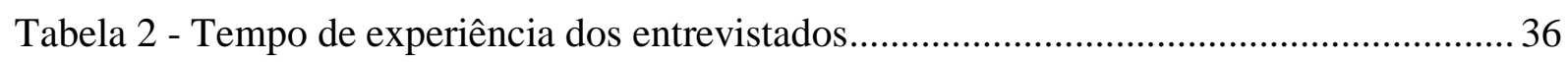

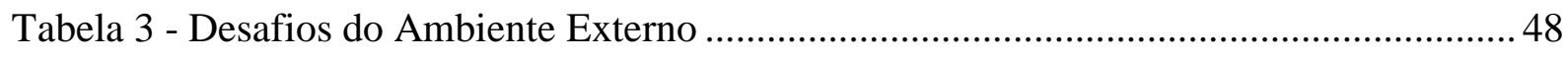

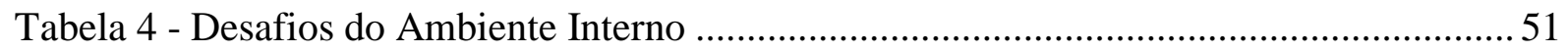

Tabela 5 - Mudanças Motivadas pela Evolução Tecnológica ................................................. 56

Tabela 6 - Necessidades e Atitudes em Relação ao Consumo ................................................ 57

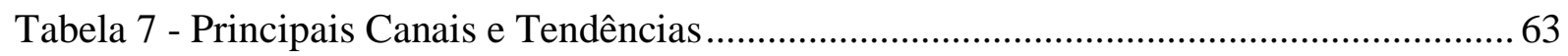

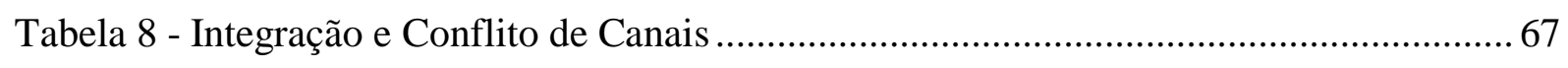

Tabela 9 - Preparação e Principais Dificuldades das Organizações ....................................... 71

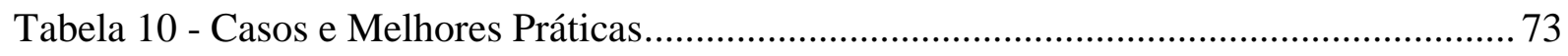

Tabela 11 - Alinhamento com Estratégia e Objetivos Organizacionais................................... 75

Tabela 12 - Envolvimento na Estratégia de Gestão de Clientes ........................................... 76

Tabela 13 - Principais Mudanças e Impactos nas Organizações ............................................... 77

Tabela 14 - Captura de Dados e Criação de Visão Única ....................................................... 78

Tabela 15 - Análises e Segmentação da Base de Consumidores ............................................ 79

Tabela 16 - Planos de Interação com Segmentos de Consumidores ........................................ 81

Tabela 17 - Desenho de Programas de Relacionamento / Fidelidade ..................................... 82

Tabela 18 - Personalização de Produtos, Serviços e Interações................................................ 83

Tabela 19 - Métricas de Desempenho e Avaliação de Resultados ............................................. 84

Tabela 20 - Resultados e Criação de Valor para Acionistas .................................................. 85 


\section{INTRODUÇÃO}

A estratégia de gestão de clientes, conhecida em algumas organizações por CRM (Customer Relationship Management), vem sendo usada em vários mercados para criação de vantagem competitiva e melhoria de resultados, por meio da manutenção e rentabilização da base de clientes (BARRETO; CRESCITELLI, 2008; GORDON, 1998; MACKENNA, 1992; VAVRA, 1993). No varejo, essa prática ainda é relativamente recente, porém vem ganhando espaço em estudos acadêmicos e nas agendas dos executivos, os quais precisam saber lidar com diferentes perfis de consumidores em ambientes cada vez mais competitivos e complexos.

No entanto, essa é implementação é bastante tortuosa devido às características internas das organizações e à própria cultura do varejo brasileiro, muito orientada a categorias de produtos, performance de canais e resultados em vendas. O desafio é ainda maior para varejistas que atuam com múltiplos canais de vendas, pós-vendas, relacionamento e comunicação, tanto físicos (off-line) quanto digitais (on-line), já que, normalmente, a gestão dos principais canais é realizada por departamentos ou unidades de negócios separadas ou com pouca integração.

Diante disso, sob a ótica das organizações do varejo (e não da indústria), o intuito do estudo é, inicialmente, analisar a estratégia de gestão de clientes no varejo em ambiente multicanal, considerando o cenário competitivo, as mudanças no comportamento do consumidor, as características das organizações e o surgimento de novas tecnologias para conhecimento e interação com consumidores.

Complementarmente, com base nos resultados obtidos, pretende-se contribuir com a prática por meio de uma proposta de intervenção e inovação empresarial no setor varejista brasileiro, de qualquer segmento, especialmente de médio e grande porte, que considere modelos conceituais e recomendações de iniciativas para a implementação da estratégia em ambiente multicanal, podendo também ser aplicada na criação de novos serviços de marketing ou consultoria.

Para a teoria, a partir da comparação com a prática e com os resultados da pesquisa, pretendese contribuir com propostas de novos estudos para melhoria e avanço do referencial existente. 


\subsection{Estrutura do Trabalho}

De forma inversa ao mestrado acadêmico tradicional, que vai "da teoria à prática", o trabalho de mestrado profissional se inicia com um relato prático, normalmente vivenciado pelo próprio autor, que depois vai em busca de conhecimentos na teoria existente e em pesquisa empírica para relacioná-los e compará-los com a sua experiência prática e, assim, contribuir para o desenvolvimento da prática nas organizações e propor novas teorias ou estudos futuros.

Pelo modelo de Sharlanova (2004), neste processo, o estudante parte do relato da experiência concreta ("fazer") ou da observação reflexiva ("observar"). Após refletir sobre a prática que foi relatada, o mesmo procura compreender as teorias relacionadas (“pensar") para, então, planejar como usará conceitos teóricos identificados para mudar sua prática (“experimentar”).

A figura a seguir ajuda a compreender como funciona este ciclo "da prática para a teoria" no contexto do Programa de Mestrado Profissional em Empreendedorismo.

Figura 1 - Ciclo "da prática para a teoria"

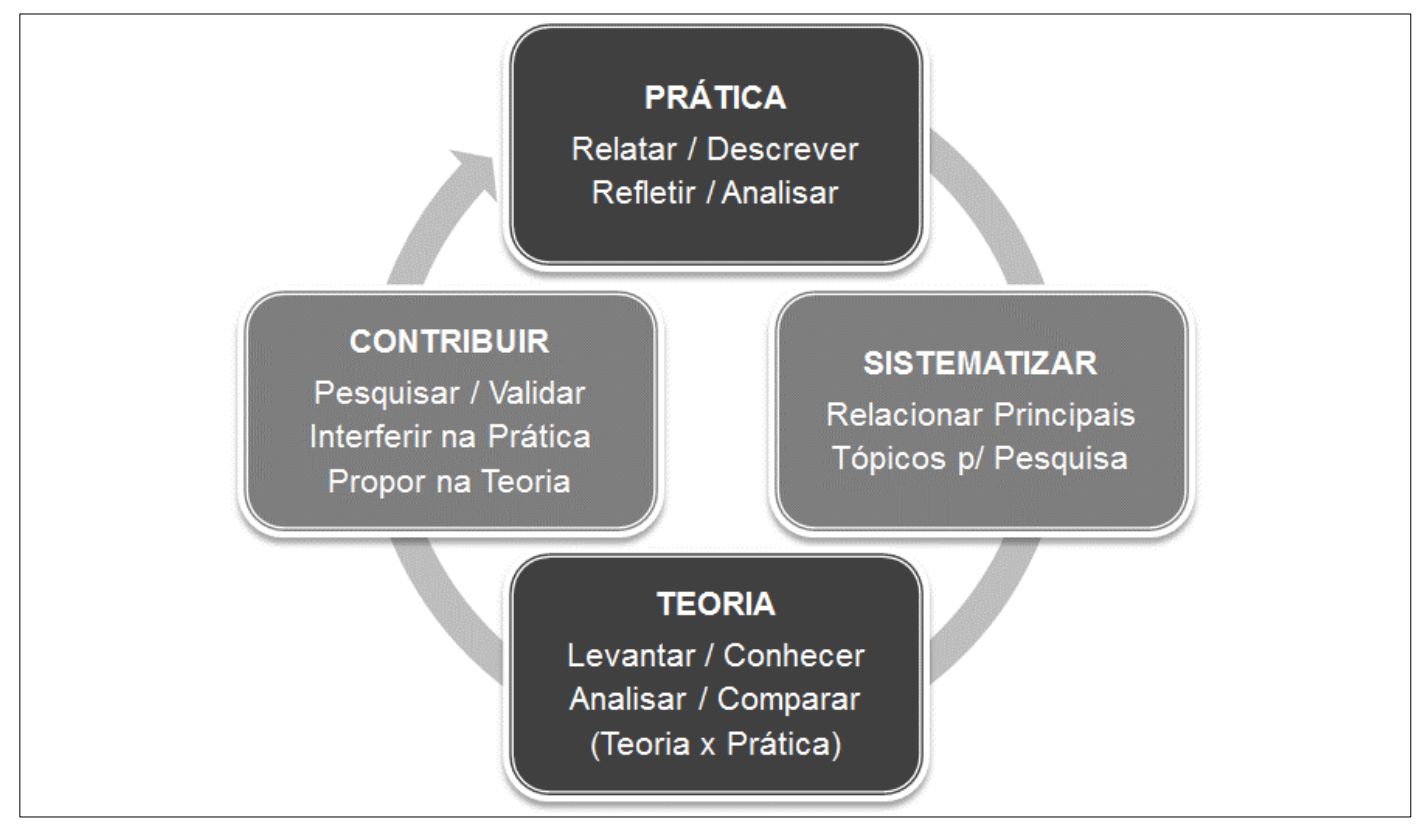

Fonte: Adaptado pelo autor de Sharlanova (2004).

O processo inicia com a descrição da experiência prática, que é analisada visando identificar as lacunas para o estudo. Depois, o pesquisador relaciona os principais tópicos para pesquisa e, assim, começa a sistematizar o ciclo da prática para a teoria. Então, os tópicos são levantados, analisados e comparados com o referencial prático. Na sequência, a pesquisa empírica permite 
validar os aprendizados da comparação realizada e atingir os objetivos propostos no trabalho, por meio de contribuição para a prática (interferência) e sugestões de novas teorias ou estudos, fechando o ciclo.

Considerando o modelo proposto para um mestrado profissional, este trabalho foi elaborado de acordo com a estrutura representada na figura a seguir.

Figura 2 - Estrutura do trabalho de mestrado profissional

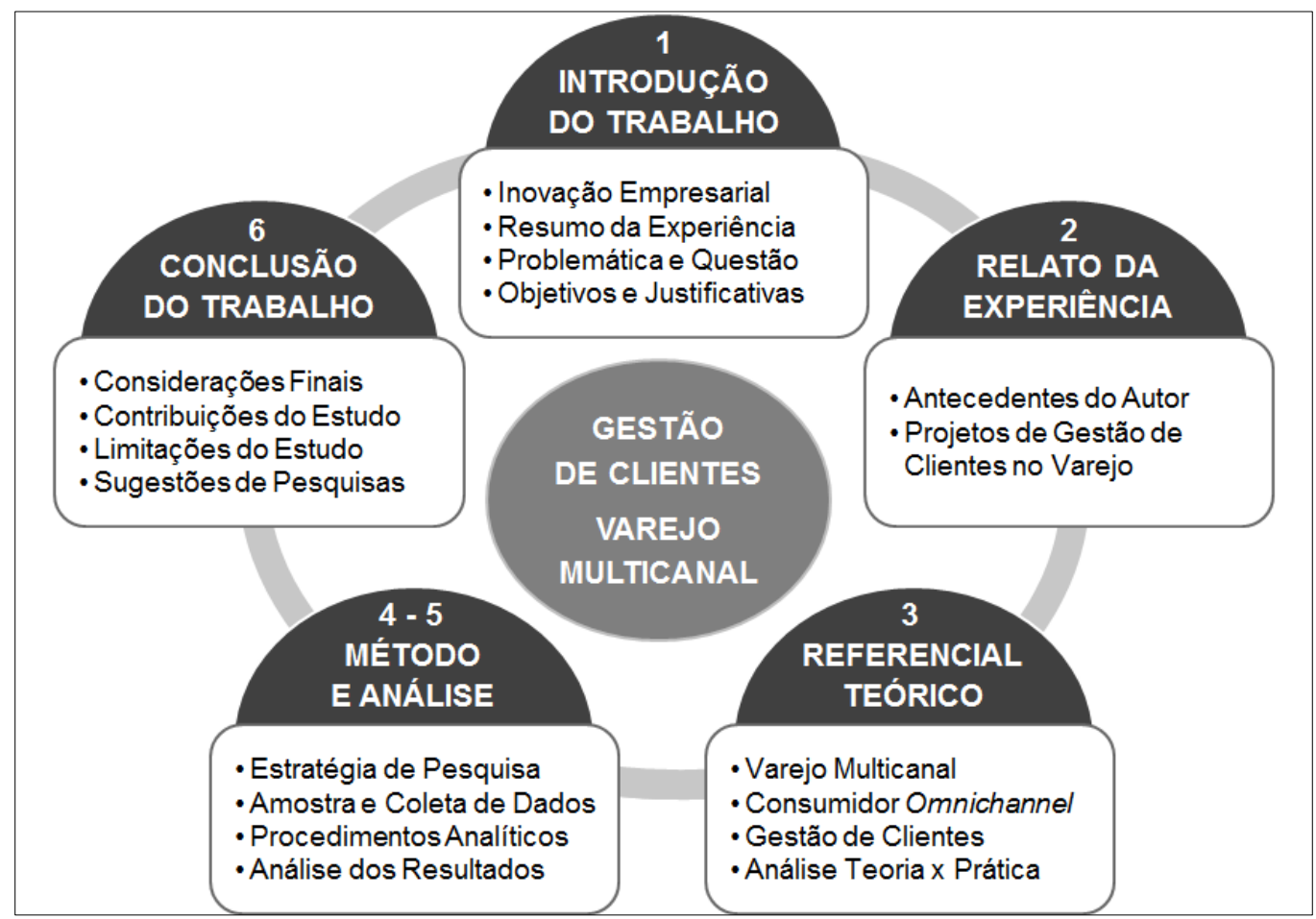

Fonte: Elaborado pelo autor.

Na primeira parte do trabalho (introdução), além do breve conceito de inovação empresarial, é apresentado um resumo da experiência do autor, o problema observado na prática, a definição da questão de pesquisa, os objetivos do estudo e as justificativas decorrentes. Na segunda parte, o relato empírico da experiência é elaborado com mais detalhes. Nele se incluem a descrição de projetos de gestão de clientes no varejo, concebidos com a participação do autor.

A terceira parte se estrutura a partir do referencial teórico, onde são abordados os conceitos relativos a varejo multicanal, consumidor omnichannel e gestão de clientes. É realizada uma breve análise acerca da abordagem teórica em relação à prática, visando reforçar os objetivos do estudo e direcionar a pesquisa empírica. 
As partes quatro e cinco contemplam a realização da pesquisa empírica, com a definição da metodologia de pesquisa, incluindo estratégia, amostragem, coleta de dados e procedimentos analíticos, e a análise dos resultados obtidos.

Por fim, na sexta parte é apresentada a conclusão do trabalho, com as considerações finais, as conclusões e as contribuições do estudo, tanto para perspectiva prática quanto teórica, bem como, as limitações metodológicas e de execução e as recomendações de novas pesquisas.

\subsection{Inovação Empresarial}

Uma das motivações do autor para o desenvolvimento deste trabalho é a contribuição para a inovação empresarial e o empreendedorismo interno nas organizações de varejo, alinhado ao propósito e às linhas de pesquisa do Programa de Mestrado Profissional.

Para contextualizar a linha de pesquisa escolhida para este trabalho, o conceito de inovação empresarial é apresentado brevemente a partir do Manual de Oslo (OCDE, 2005). Elaborado pela Organização para a Cooperação e Desenvolvimento Econômico, este documento é usado como referência para pesquisas em inovação nos países mais desenvolvidos.

Conforme consta no manual, o conceito de inovação pode ser caracterizado pela implementação de um produto novo (ou significativamente melhorado). Ele também pode remeter a um processo, um método de marketing ou um método organizacional. Assim, os tipos de inovação podem ser agrupados em:

- Inovação de produto: um bem ou serviço;

- Inovação de processo: um método de produção ou distribuição, que geralmente envolve técnicas, equipamentos e/ou softwares;

- Inovação de marketing: um método de concepção de um produto, como a sua embalagem, posicionamento, promoção, preços ou vendas;

- Inovação organizacional: um método referente às práticas de negócios de uma empresa, à organização do trabalho ou às relações externas. 
Um conceito relacionado é a inovação radical ou "disruptiva", aquela que causa um impacto significativo em um mercado e na atividade econômica das organizações nesse mercado. Em relação ao grau de novidade, a inovação pode ser:

- Nova para a empresa (mesmo se já aplicada em outra empresa ou mercado);

- Nova para o mercado (primeira empresa a introduzir a inovação em seu mercado);

- Nova para o mundo (primeira empresa a introduzir a inovação em todos os mercados e indústrias, domésticos ou internacionais).

O conceito de inovação refere-se também a mudanças caracterizadas pelos seguintes aspectos:

- A inovação está associada às incertezas sobre os resultados das atividades inovadoras;

- Geralmente envolve investimentos;

- Os benefícios da inovação criadora são raramente apropriados por completo pela empresa;

- Requer a utilização de conhecimento novo, ou um novo uso, ou a combinação com um conhecimento existente;

- A inovação visa melhorar o desempenho de uma organização com o ganho ou manutenção de uma vantagem competitiva.

Para este estudo, que procura analisar a implementação da estratégia de gestão de clientes no varejo multicanal sob perspectiva dos varejistas, as inovações envolvidas são principalmente de marketing e organizacional, podendo ocorrer de serem novas para a empresa e mesmo para o mercado, dependendo do segmento de atuação da organização de varejo.

Em relação aos seus aspectos, a inovação por meio da estratégia de gestão de clientes envolve investimentos financeiros e/ou estruturais, incertezas sobre os resultados, requer conhecimentos novos para a organização e visa melhorar o desempenho com o ganho de vantagem competitiva. 


\subsection{Resumo da Experiência}

A inspiração para desenvolvimento deste trabalho surgiu da experiência profissional de mais de 20 anos do autor em diversas funções e disciplinas ligadas a marketing, CRM - Customer Relationship Management, entendida aqui como uma estratégia de negócios com orientação a clientes, e marketing de relacionamento, esta última entendida como estratégia de marketing e comunicação para o aprofundamento da relação com clientes. Nos últimos seis anos, o autor do presente estudo atuou como gerente ou consultor em projetos para o setor de varejo.

Com base na experiência obtida, pode-se constatar que os conceitos e ferramentas de gestão de clientes estão bem disseminados em diversos setores, como financeiro e telecomunicações. A gestão de clientes é uma função chave nas organizações que atuam nestes mercados, caracterizados por prestarem serviços recorrentes, de relacionamento contínuo e fácil identificação dos consumidores e suas transações. Os principais desafios destes setores residem na aquisição / conquista de novos clientes, na manutenção (fidelização) dos clientes atuais e no desenvolvimento da base (rentabilização), com foco nos clientes de maior valor (BARRETO; CRESCITELLI, 2008; PEPPERS; ROGERS, 2001; VAVRA, 1993).

Em relação ao setor varejista brasileiro, as organizações têm demonstrado uma visão limitada acerca de como a gestão de clientes pode ajudar na busca de eficácia e eficiência em seus negócios, embora apresentem diversas iniciativas táticas e pontuais.

Por outro lado, a metodologia para implementação e melhores práticas observadas em outros setores não necessariamente se adaptam às organizações do setor de varejo, em razão de suas particularidades internas, nível de complexidade do mercado e pouca maturidade do setor em relação ao assunto.

Entretanto, observa-se um aumento do interesse sobre o tema, seja por meio de publicações, artigos ou eventos, além de uma crescente procura de varejistas por consultoria estratégica e serviços nesta área, embora ainda com pouca cultura e conhecimento efetivo do valor que a gestão de clientes pode agregar às organizações e seus consumidores.

Da mesma forma que em outros mercados bastante competitivos e com baixa diferenciação entre concorrentes, é possível acreditar que no varejo as organizações possam desenvolver 
vantagem competitiva e gerar valor pelo relacionamento profundo com seus consumidores, o que pode ser considerado uma inovação para a organização e até mesmo para o setor.

Para alcançar este patamar, as organizações precisam conhecer seus clientes profundamente e, então, propor interações relevantes e personalizadas, em busca de maior satisfação e lealdade, contribuindo para o alcance dos objetivos corporativos (PEPPERS; ROGERS, 2001). A estratégia de orientação a clientes pode ser também uma fortaleza em momentos de crise econômica ou entrada de concorrentes, pois protege a base de consumidores da organização, especialmente os considerados de alto valor.

\subsection{Problemática e Questão de Pesquisa}

Além do cenário de alta competição, a estratégia de gestão de clientes ganha maior importância em ambientes de atuação multicanal, onde o grande desafio é a integração de canais físicos e digitais de vendas, pós-vendas e relacionamento, visando garantir a melhor experiência possível ao consumidor, tendo como consequência o aumento da satisfação e fidelização, além de gerar oportunidades para alavancar receitas e reduzir custos.

Também deve-se levar em conta as mudanças no comportamento do consumidor nos últimos anos, principalmente com o crescimento dos meios digitais. Este novo consumidor é bastante informado, acessa diferentes canais para pesquisa e compra de produtos e serviços, busca recomendações, é menos fiel às marcas e mais consciente dos seus direitos.

Neste ambiente complexo, os processos de negócios devem ser revistos, apoiados por novas tecnologias baseadas na internet e em dispositivos móveis, bem como pelo grande volume e variedade de informações sobre consumidores, potencializando a estratégia.

No ambiente interno, algumas características presentes na maioria das organizações de varejo no Brasil contribuem para o desafio de implementar a estratégia de gestão de clientes:

- Existem pouco conhecimento e cultura de gestão de clientes no varejo brasileiro. Boa parte das organizações são familiares e começaram a se profissionalizar há poucos anos; 
- Na maioria dos segmentos de varejo as margens são pequenas e, por isso, as organizações focam seus esforços na negociação com seus fornecedores ("saber comprar") e na atração dos consumidores por meio da oferta de preços baixos e promoções (“saber vender”), com gestão ativa dos canais de vendas e categorias de produtos;

- Prevalece a comunicação de massa para atrair consumidores ao ponto-de-venda, muitas vezes em ação cooperada com os fabricantes de bens de consumo;

- Apesar da grande quantidade de dados disponíveis, incrementado pelo maior volume por meios digitais, são poucos os varejistas que conhecem seus consumidores individualmente, pois não existem processos de captura de dados e as informações estão espalhadas;

- Os pontos de contato com os consumidores geralmente não estão integrados, ou seja, não compartilham informações (visão única) e a mesma abordagem para venda e pós-venda.

Dessa forma, os processos, métodos e práticas existentes para implementação da estratégia, bem consolidados em outros setores, devem ser adaptados para melhor atender às características do varejo em ambiente multicanal e bastante complexo.

Figura 3 - Fatores ambientais que impactam a gestão de clientes no varejo

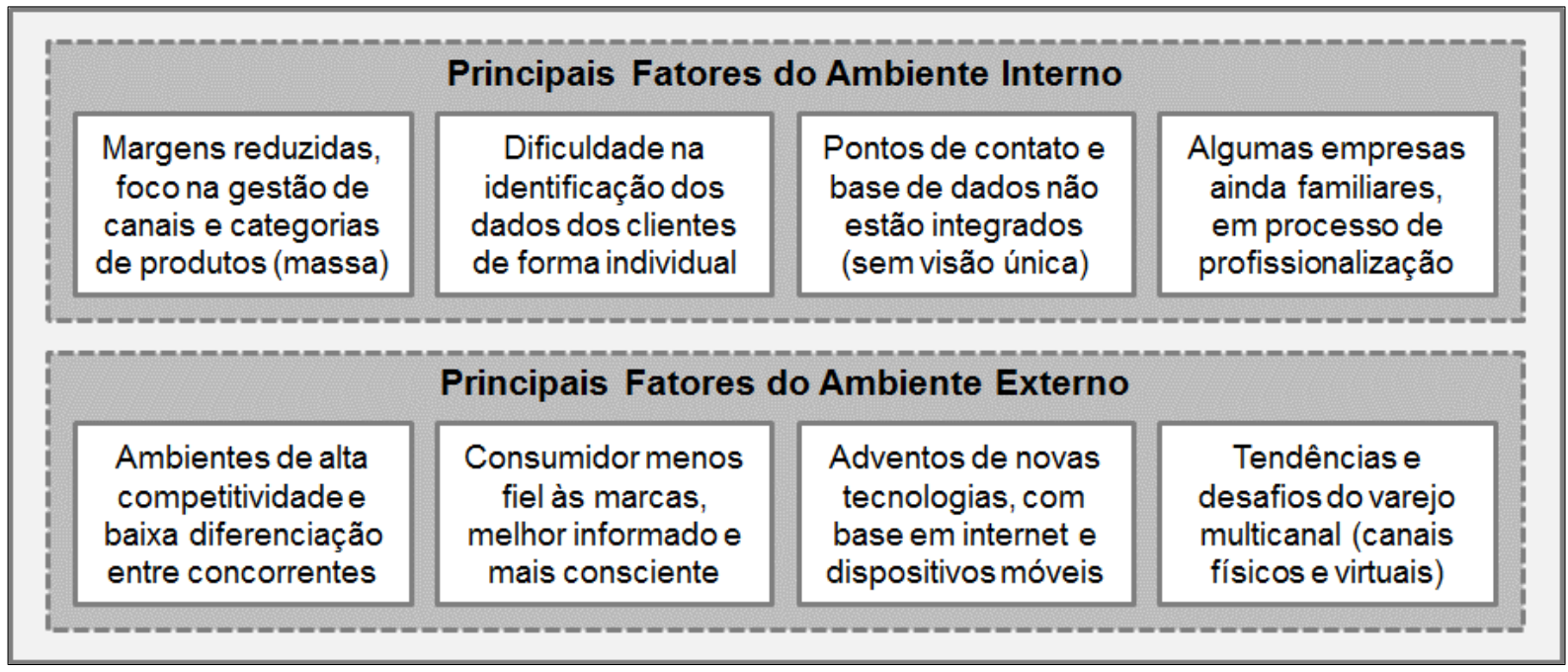

Fonte: Elaborado pelo autor.

Diante do contexto abordado no relato da experiência, como também do ponto de vista conceitual, a questão central de pesquisa que é: quais são as diretrizes para implementação de estratégia de gestão de clientes em organizações que atuam no varejo multicanal, considerando as características e desafios dos ambientes interno e externo? 


\subsection{Objetivos Gerais}

A partir da questão de pesquisa levantada, os objetivos deste estudo são: i) entender o cenário competitivo do varejo brasileiro e as características das organizações com atuação multicanal; ii) identificar e analisar elementos da estratégia de gestão de clientes a partir dos seus principais processos; ii) sugerir diretrizes para implementação da estratégia de gestão de clientes em organizações de varejo multicanal de qualquer segmento.

\subsection{Justificativas do Projeto}

O acirramento da competição no setor de varejo, especialmente após o surgimento da internet, a possibilidade de interação com clientes em múltiplos canais, as mudanças no comportamento dos consumidores e o aparecimento de novas tecnologias de informação e mobilidade, levam as organizações a repensarem suas estratégias de negócios e relacionamento com clientes.

Neste cenário, pela experiência do autor, assim como ocorreu em outros setores, existe clara oportunidade de criar vantagem competitiva a partir de estratégia de gestão de clientes que permita aprofundar o conhecimento e relacionamento com consumidores. Para tanto, algumas barreiras culturais do setor devem ser quebradas e novas diretrizes devem ser seguidas.

Reforçando a importância da pesquisa, além de termos poucos casos de sucesso no Brasil, as estratégias no varejo multicanal ainda são pouco exploradas pela academia, conforme apurado por DIAS (2014). Também são poucos os livros publicados e os estudos normalmente focam a indústria de bens de consumo, considerando o setor varejista como um mero distribuidor de produtos ao mercado consumidor.

Adicionalmente, alguns tópicos aplicados à gestão de clientes em ambiente multicanal fazem parte da lista prioritária de pesquisas acadêmicas para o período de 2014-2016 do Marketing Science Institute (2015): o entendimento do comportamento e experiência dos consumidores (classificado como nível um), o desenvolvimento de métodos analíticos de marketing e o reconhecimento de diferenças entre os consumidores. 
Dessa forma, conclui-se que a estratégia de gestão de clientes neste cenário é tema relevante a ser pesquisado. Espera-se que os resultados das análises do relato prático, do referencial teórico e dos resultados obtidos com a pesquisa empírica, possam ser utilizados para intervenção na prática em organizações de varejo multicanal e para avanços nos estudos.

Como contribuição para os negócios, a intervenção proposta deve vislumbrar a melhoria dos processos e dos resultados das organizações do setor, sejam elas generalistas ou especialistas. Assim sendo, espera-se auxiliar na ampliação do faturamento e da rentabilidade, a partir do incremento do volume de vendas, e na maior fidelidade dos consumidores. Esta última deverá ser impulsionada pela evolução no conhecimento dos clientes e na experiência de consumo. 


\section{RELATO DA EXPERIÊNCIA}

\subsection{Antecedentes do Autor}

Neste tópico, o autor do presente trabalho apresenta de forma breve seus antecedentes profissionais. Esta exposição servirá de apoio ao entendimento do relato empírico que será desenvolvido no decorrer do estudo.

O autor possui vivência profissional em marketing e comunicação desde 1994, tendo ocupado durante mais de 15 anos posições de liderança em gestão de clientes (CRM), marketing de relacionamento, database marketing e inteligência de mercado. Atuou como gerente ou consultor em mais de 30 projetos de aquisição, fidelização e rentabilização de clientes, para organizações nacionais e multinacionais, como colaborador efetivo ou por meio de consultorias especializadas.

No âmbito acadêmico, além de trabalhos realizados na graduação e pós-graduação lato sensu, o autor possui 9 anos de experiência como professor de ensino superior (graduação) em disciplinas correlatas às áreas de atuação, em instituição de reconhecida reputação nas áreas de Marketing e Comunicação. É também palestrante eventual em outros cursos e eventos.

De 2010 a 2014, exerceu a posição de Gerente de Projetos em uma prestigiada consultoria internacional em estratégica de negócios, especializada em gestão de clientes, que desenvolve projetos para organizações de diversos setores da economia, como agronegócio, financeiro, bens de consumo e varejo, o que permitiu o aprofundamento em projetos neste último setor.

Entre 2014 e 2015, atuou como Gerente de CRM e Inteligência de Mercado em uma grande e tradicional organização brasileira nos setores de varejo de livros, editora e sistemas de ensino, com foco em cultura, diversão e entretenimento e atuação multicanal em lojas físicas, $e$ commerce e meios digitais, o que despertou a atenção e o interesse nos temas deste trabalho. 


\subsection{Gestão de Clientes no Varejo}

Pela observação e vivência do autor, conceitos, estratégias e iniciativas de gestão de clientes estão bem disseminadas em alguns setores como o de telecomunicações e financeiro, por exemplo, pois estes constituem serviços de relacionamento contínuo e de fácil identificação individual dos clientes.

Já as organizações do varejo brasileiro apresentam visão limitada sobre a gestão estratégica de clientes e, consequentemente, possuem uma compreensão insuficiente de como ela pode contribuir para maior eficácia e eficiência de seus negócios, embora apresentem algumas iniciativas táticas e pontuais. No entendimento do autor, essa limitação estratégica é proveniente de uma questão cultural que vem mudando nos últimos anos com a maior profissionalização do setor, em especial nas organizações de gestão familiar pressionadas pela forte concorrência e entrada de novos players.

A estratégia para atração de consumidores aos pontos de venda é baseada em comunicação massiva e posicionamento de preços e promoções. Muitas vezes, estas ações são realizadas em conjunto com a indústria de bens de consumo / produtos.

Por outro lado, a competição no setor está cada vez maior e, por sua vez, os consumidores são cada vez menos fiéis, pois têm muito maior acesso a informações e opções de compra. Nesse contexto, os varejistas que conhecem seus melhores clientes individualmente, interagem com eles de forma relevante, sistemática e personalizada e atuam constantemente para melhorar a experiência de compra e utilização dos seus produtos e serviços, podem criar diferenciais em relação aos concorrentes (PEPPERS; ROGERS, 1993; 2001).

Poucos varejistas conseguem completar este ciclo, pois dependem fortemente do levantamento das características individuais dos clientes como ponto de partida. Apesar do volume abundante e crescente de dados disponíveis sobre os consumidores, proveniente tanto de origens internas como externas, a maior parte das organizações de varejo não conhece seus consumidores individualmente, o que inviabiliza o desenvolvimento de uma relação orgânica e sistemática de aprendizado entre a organização e seu público-alvo. 
Esse fenômeno se deve ao fato de que diversas fontes de dados geralmente estão desintegradas (cadastros, transações, manifestações, interações, opiniões, etc.) e espalhadas em vários pontos de contato, como lojas físicas, serviços de atendimento, programas de fidelidade, redes sociais, sites na internet, aplicativos e pesquisas.

Com base na participação de projetos nos setores de varejo e serviços, para o autor, algumas iniciativas parecem consolidadas e são importantes para que a estratégia de gestão de clientes seja bem-sucedida:

- Apropriação e "patrocínio" da estratégia pela alta direção da organização;

- Definição da área responsável pela gestão de clientes, normalmente a área de Marketing, com reporte direto à presidência e interação com as áreas envolvidas no relacionamento;

- Alinhamento e sinergia dos conceitos, expectativas, objetivos e metas de gestão de clientes com as diretrizes corporativas, e definição dos indicadores chave de performance (KPIs Key Performance Indicators) para monitoramento constante;

- Desenvolvimento de plano de ação (Roadmap) com iniciativas de gestão do conhecimento (Analytics) e da experiência dos clientes (Relationship) e de gestão de mudanças;

- Criação de repositório de dados para marketing (Database Marketing) com visão única e individual de clientes, com informações captadas e tratadas de origens internas e externas;

- Definição de elementos críticos de dados (ECD's) e de processos para captura destes nos principais pontos de contato com os consumidores;

- Desenvolvimento de modelos estatísticos de segmentação por valor atual e potencial (ex.: faturamento e/ou margem), por comportamento de compra (ex.: "recência", frequência, valor e categorias), por hábitos de consumo (ex.: dias e horários de compra, formas de pagamento) e modelos preditivos de comportamento (ex.: compra de produtos, inativação);

- Pesquisas com consumidores dos segmentos (Clusters) definidos, para entendimento do comportamento, necessidades, interesses, desejos em relação à organização e concorrentes;

- Mapeamento dos pontos de contato, canais de atendimento, ciclo de vida dos clientes, jornadas de compra e motivos de relacionamento;

- Desenho de plano de interação nos pontos de contato para cada segmento (ex.: canais de atendimento, campanhas de relacionamento, programas de fidelidade, serviços exclusivos);

- Planejamento e execução de réguas e campanhas de relacionamento em múltiplos canais, com mensuração e avaliação dos resultados (receita de vendas e retorno sobre investimento); 
- Definição de métodos e processos para personalização de serviços, produtos, atendimento, comunicação, ofertas, canais, eventos, etc.

- Definição de processos para coleta e análise de feedback de clientes nos pontos de contato, com disseminação de informações e execução de melhorias contínuas (programa "Voz do Cliente" ou "VoC - Voice of Customer");

- Desenho de processos de gestão de clientes e seleção de tecnologia (softwares) adequadas para automação dos ambientes analíticos (conhecimento) e operacionais (relacionamento);

- Desenho de plano de gestão de mudanças (cultura organizacional) com foco nos clientes, que envolva revisão de estrutura, treinamento, incentivo, remuneração (PLR - Participação em Lucros e Resultados) e comunicação interna;

- Criação de Comitê de Clientes com participação dos líderes de todas as áreas (Marketing, Comercial, Operações, Finanças, Tecnologia e Recursos Humanos) e implementação de fóruns periódicos para definição de diretrizes estratégicas, juntamente com a avaliação dos indicadores e das principais iniciativas.

A figura a seguir resume a visão estratégica e as boas práticas de gestão de clientes no setor de varejo, conforme a experiência relatada pelo autor.

\section{Figura 4 - Visão da estratégia de gestão de clientes no varejo}

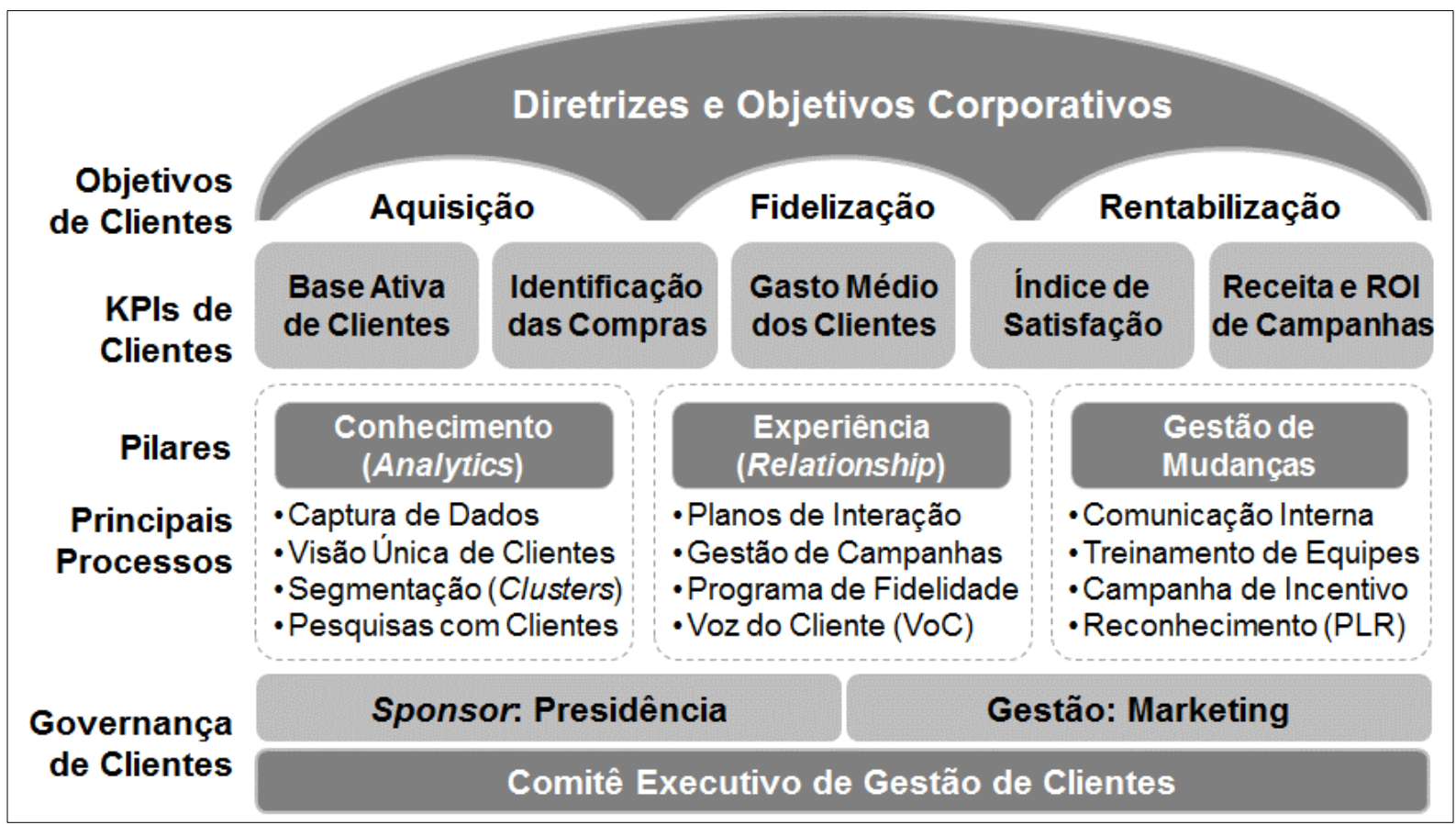

Fonte: Elaborado pelo autor. 
Durante a elaboração de um projeto de gestão de clientes no varejo, com participação do autor como gerente de consultoria nos anos de 2012 a 2014, e após a implementação de boa parte das inciativas citadas, uma rede de supermercados com participação de mercado bastante relevante no estado de São Paulo pôde incrementar seu faturamento anual em torno de 2,5\%, por meio de campanhas de relacionamento personalizadas.

O projeto foi considerado bem-sucedido pela organização e pelo mercado, pois permitiu o aprimoramento do conhecimento e do relacionamento com seus consumidores, propiciando uma maior compreensão acerca de suas características, obtendo assim ótimos ganhos financeiros. Pela inovação, a organização também foi contemplada com importante prêmio internacional por aliar tecnologia e práticas analíticas com ações de marketing - conquista amplamente divulgada pela imprensa especializada, com geração de mídia espontânea.

A dúvida que se apresenta é se a estratégia e as iniciativas indicadas são sustentáveis diante das mudanças recentes no setor varejista, sendo que estas devem ser intensificadas nos próximos anos. Elas incluem, principalmente, as questões do ambiente multicanal e das mudanças no comportamento dos consumidores. Desse modo, o presente trabalho procurará entender as implicações e, consequentemente, consolidar as diretrizes para a estratégia de gestão de clientes diante do cenário apresentado. 


\section{REFERENCIAL TEÓRICO}

Nesse tópico, serão revisados de forma breve os conceitos relativos à Varejo Multicanal, Consumidor Omnichannel e Gestão de Clientes. A figura a seguir relaciona a exposição da experiência prática com as teorias a serem estudadas e suas principais referências.

\section{Figura 5 - Relação entre relato da experiência e referencial teórico}

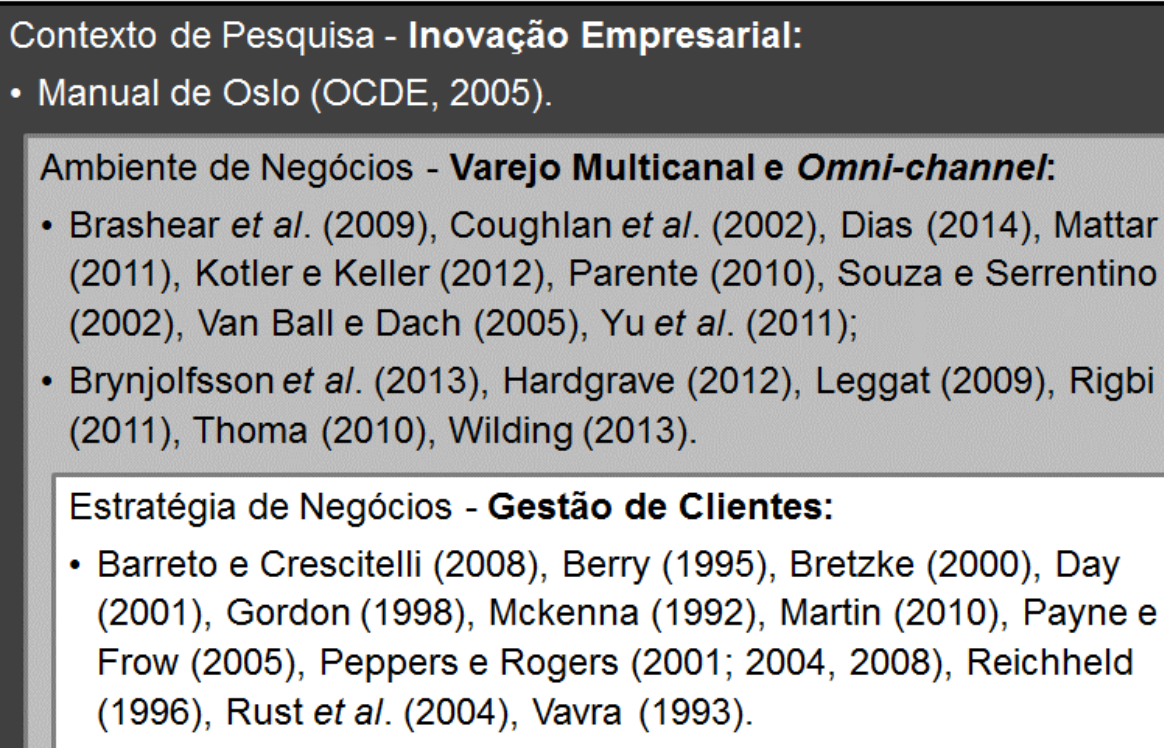

Fonte: Elaborado pelo autor.

\subsection{Varejo Multicanal}

Do ponto de vista da indústria de bens, o varejo se encaixa no sistema de distribuição, que "é o conjunto de atividades que disponibilizam o produto no mercado tornando-o acessível ao público" (KOTLER; ARMSTRONG, 1999). Peter e Churchill (2000), conceituam o varejista como "intermediário que se dedica principalmente a vender para consumidores finais". Após comprar mercadorias direto de fabricantes ou atacadistas, os varejistas dedicam-se às vendas individuais aos consumidores, geralmente em lojas.

Por natureza, o varejo é um dos setores mais importantes da economia brasileira e mundial. O surgimento da internet e os crescentes avanços da tecnologia da informação contribuíram para 
o desenvolvimento deste setor juntamente com a cadeia de distribuição e logística. As mudanças contínuas no comportamento dos consumidores, cada vez mais informados e exigentes, fazem com que as organizações tenham que se adaptar e revisar constantemente o posicionamento de produtos, marcas e canais de distribuição (MATTAR, 2011; PARENTE, 2010).

O consumidor também assume necessidades e desejos distintos à medida em que as mudanças demográficas e sociais acontecem, e essas alterações influem diretamente no perfil das famílias e no papel dos indivíduos no processo de compras, conforme abordado por Souza e Serrentino (2002).

Com a evolução tecnológica, canais de vendas, pós-vendas (relacionamento e atendimento) e comunicação foram criados ou aprimorados. A expectativa é que os canais se complementem e estejam totalmente integrados para melhorar a experiência do consumidor e aumentar as vendas, considerando que um cliente que compra em mais de um canal consome mais produtos e, por consequência, é muito mais valioso para a organização. Também deve-se levar em conta que este consumidor tende a ficar mais satisfeito diante de mais ofertas e alternativas, fortalecendo a relação de lealdade para com a empresa, o que aumenta a chance de recompra e o seu tempo de permanência na condição de cliente da mesma (PARENTE, 2010).

A tecnologia automatizou processos e serviços, permitindo que os consumidores pudessem exercer o autoatendimento de maneira mais produtiva e menos onerosa para a organização, gerando menos atrito e mais satisfação para eles mesmos (COGHLAN et al., 2002). As inovações tecnológicas também permitiram que o consumidor fosse identificado de forma individual, por meio de coleta de informações nos meios digitais, o que não ocorreria de forma natural no varejo tradicional (SOUZA; SERRENTINO, 2002).

Segundo levantamento de Dias (2014), embora já aparecesse em revistas acadêmicas nos anos 1970 e 80, o termo "multicanal" ganhou força no final dos anos 90, com grande crescimento em meados dos anos 2000. Kotler e Armstrong (1989) definiram especificamente "marketing multicanal" como o arranjo para vendas a partir da segmentação de clientes e possibilidades de canais de distribuição.

Com o crescimento do comércio eletrônico (e-commerce), a estratégia multicanal entrou na pauta de grandes organizações varejistas como forma de atender melhor os consumidores nos 
canais de sua preferência e conveniência para venda e pós-vendas - sejam estes canais físicos ou digitais - e assim entregar e conseguir maior valor nesta relação (MATTAR, 2011). O consumidor consegue, por exemplo, comprar pela internet e receber na loja física, podendo ainda escolher o canal para troca ou resolução de problemas. Ele também pode comprar produtos de forma on-line em dispositivos na loja, como totens interativos, computadores ou tablets, que reduzem a ruptura e perda de vendas.

Embora a internet já esteja inserida na rotina dos consumidores, ela não funciona somente para a realização de compras, mas também para comunicação e pesquisa de produtos (BRASHEAR et al., 2009), uma vez que as lojas físicas ainda respondem pela maior parte das compras. Com o crescimento acelerado da audiência e das vendas pela internet, especialmente em países em desenvolvimento, os varejistas tradicionais estarão atentos ao comportamento do consumidor multicanal e à melhor forma de atendê-lo.

As interações e compras de forma multicanal podem acontecer por meio de canais físicos (offline), como lojas, quiosques, catálogos, venda pessoal e por telefone. Elas podem ainda realizarse virtualmente (on-line), através de web sites, aplicativos e redes sociais em dispositivos fixos (computadores e totens) ou ainda pelos aparelhos móveis (tablets e smartphones). Neste cenário, os consumidores têm mais opções para buscar informações e comprar, conforme a revisão feita por Yu et al. (2011).

Um dos principais desafios enfrentados neste meio reside na volatilidade do consumidor, uma vez que ele pode fazer sua pesquisa com um fornecedor e fechar negócio com outro. Esse comportamento é denominado free-riding ("pegar carona"), conforme exposto por Dias (2014), e, como decorrência dele, podem ocorrer possíveis conflitos de canais dentro da própria organização, conforme abordado por Coughlan et al. (2002) e Van Baal e Dach (2005).

O comportamento free-riding no varejo multicanal pode beneficiar os consumidores, ampliando seu acesso a informações e canais disponíveis dos diversos varejistas e possibilitando que eles decidam melhor a sua compra sem precisar pagar mais por isso, pois os varejistas não têm como cobrar ou identificar este consumidor, e nem tampouco cooperam entre si para que isso seja possível (DIAS, 2014). Um exemplo desse comportamento: quando o consumidor pesquisa e experimenta o produto em loja física de um varejista e depois compra mais barato no e-commerce de um concorrente com melhor preço. Neste caso, o primeiro 
funcionou como show-room gratuito, pois a transação foi realizada na loja virtual de outro varejista.

Em relação aos conflitos multicanais, para Kotler e Keller (2012), estes ocorrem quando dois ou mais canais da organização vendem para o mesmo segmento de consumidores, com custos, preços e condições diferentes. É o caso da maioria dos varejistas com atuação multicanal no Brasil. Por outro lado, alguns fabricantes também começaram a atender o consumidor de forma direta com lojas físicas e virtuais, reduzindo o poder e dependência dos varejistas e tornando possível a gestão ativa dos consumidores, não apenas das categorias de produtos (Coughlan et al., 2012).

Em geral, os novos canais digitais são criados de forma desintegrada, em estruturas separadas e que pouco conversam com o legado da organização. Respeitando as características de cada canal, a integração e a sinergia entre eles torna-se fundamental, devido às vantagens já relatadas ao consumidor e aos benefícios trazidos para a própria organização, que passa a ter a possibilidade de conseguir sistematizar informações e conhecer mais a fundo as características de seus consumidores. Essa estratégia também permite o aprofundamento da relação entre empresa-cliente, além de proporcionar experiências mais positivas, contribuindo para o desenvolvimento de uma visão estratégica, para a criação de cultura multicanal e para melhoria dos seus resultados (SOUZA; SORRENTINO, 2002).

\subsection{Consumidor Omnichannel}

A evolução do varejo multicanal, das mídias digitais e dos dispositivos móveis propiciou a ascensão de um novo perfil de consumidor: omnichannel. Este consumidor busca todas as formas e canais de consumo, atendimento, engajamento e comunicação com a marca.

Segundo Leggat (2009), nos EUA os consumidores omnichannel irão gastar entre 15\% e 30\% a mais que consumidores multicanais comuns. Além disso, eles influenciam outros através das redes sociais e demonstram forte lealdades às marcas.

Para Thoma (2010), este consumidor está sempre bem informado e conectado. Ele escolhe de forma criteriosa os bens que adquire e pode utilizar vários canais simultaneamente, como lojas 
físicas, internet, telefone, catálogos e dispositivos móveis. Ele exige dos varejistas uma experiência de fato multicanal e integrada para aumentar seu consumo e fidelidade.

Os canais devem estar unificados e possuir sinergia nos processos, para que o consumidor possa ter uma experiência benéfica e natural em todas as etapas de compra e relacionamento, com a manutenção das mesmas informações e da abordagem. Nesse sentido, o acesso móvel às informações é um ponto de atenção para o varejo, já que o consumidor pode consultar preços e resenhas do produto no momento da compra.

Para Rigbi (2011), o varejo omnichannel será a estratégia do futuro para os varejistas, que devem estar atentos às vantagens dos meios digitais e das lojas físicas para os consumidores, sempre buscando a máxima integração possível.

Para Wilding (2013) a diferença entre varejo multicanal e omnichannel está na integração deste último nos canais on-line e off-line, tanto no processo de compra quanto no de entrega. Para que esse processo ocorra de forma satisfatória, todas as atividades da cadeia de suprimentos devem estar integradas, de forma que a mesma informação possa estar disponível em qualquer canal.

Hardgrave (2012) afirma que, para que o varejo possa de fato criar uma experiência omnichannel, é necessário dispor de uma operação que funcione em tempo real, com controle de estoques eficientes e boa gestão dos custos.

Brynjolfsson et al. (2013) comenta que a tecnologia da informação é a área responsável por esta integração e por remover as barreiras geográficas, fornecendo informações relevantes para o consumidor. As melhores práticas dos varejos on-line e off-line devem ser adaptadas, em relação à precificação, experiência de compra e relacionamento com os consumidores. Outro aspecto levantado é a grande quantidade de dados disponibilizados pelos canais digitais, como redes sociais, dispositivos móveis e e-commerce, que permitem entender de forma profunda as transações e interações, limitadas pela capacidade da organização em sistematizar e analisar estes dados. 


\subsection{Gestão de Clientes}

Os conceitos relativos a Gestão de Clientes, tanto na academia quanto nas organizações, normalmente estão vinculados às temáticas de "Marketing de Relacionamento" e "Gestão do Relacionamento com Clientes", ou do inglês "CRM - Customer Relationship Management". Porém, vemos que não existe consenso no uso destes termos. Dependendo da perspectiva, podem ser vistos como sinônimos ou como conceitos bem diferentes.

Normalmente, o marketing de relacionamento está vinculado à estratégia de marketing para competir em mercados com muitos concorrentes e com baixa diferenciação dos produtos e serviços (MCKENNA, 1992), já que, ele é utilizado com o propósito de fidelizar os clientes por meio do estabelecimento de uma relação comercial mais profunda. Já o CRM, por sua vez, se encontra no âmbito das estratégias de negócios e de tecnologias da informação para gestão do relacionamento com clientes (BRETZKE, 2000). Ele atua de forma conjunta com sistemas de CRM Operacional, Analítico e Colaborativo, em busca de vantagem competitiva sustentável, por meio do desenvolvimento de uma relação de maior "intimidade com os clientes", em complemento às estratégias competitivas tradicionais (PORTER, 1989).

No presente trabalho, esses termos serão considerados como componentes de uma mesma estratégia de orientação para clientes, que deve ser determinada pela alta direção da organização e conduzida pela área de marketing, além de contar com o envolvimento de todas as suas áreas.

A gestão de clientes surgiu como opção estratégica em ambientes de alta competitividade, alavancada pela globalização e com baixa diferenciação entre os produtos disponíveis, graças aos avanços nas tecnologias de produção (GORDON, 1998; MACKENA 1992). Com a produção em massa, um produto que poderia representar um diferencial competitivo pode virar commodity de forma bastante rápida. Dessa forma, é muito difícil uma organização manter uma vantagem sustentável baseada em produtos (PORTER, 1989). Na visão de Peppers e Rogers (2008), "não importa o quão inovador é o seu produto hoje, amanhã será commodity".

O crescente aumento da competição, principalmente desde a década de 1980 no Brasil, foi acompanhado por grandes mudanças nas necessidades e no comportamento dos consumidores (GORDON, 1998; MACKENNA, 1992; VAVRA, 1993). Estes têm sido cada vez mais desconfiados e menos fiéis às marcas e produtos, mais conscientes das opções disponíveis e de 
seus direitos enquanto consumidor. Uma maior compreensão foi impulsionada pelo nível de educação, legislação e fácil acesso às informações, em especial com o advento da internet e mídias digitais. As grandes mudanças sociais, culturais e demográficas tornaram o consumidor mais exigente em relação aos produtos e serviços que consome, o que faz com que as empresas procurem atender as necessidades desse setor de forma cada vez mais individualizada.

Em paralelo, observou-se também uma fé reduzida e menor uso da propaganda tradicional em meios de massa pelas organizações. Esse fenômeno decorre do alto custo dispendido por essa alternativa, da dificuldade na mensuração dos resultados e da descrença pelo consumidor, favorecendo o aparecimento e a convergência de novas ferramentas e meios de comunicação “no advertising" (AAKER, 2000), mais baratos, segmentados e mensuráveis, juntamente com o advento da comunicação integrada de marketing (OGDEN; CRESCITELLI, 2007), que busca incorporar sinergia à mensagem, com integração e diversificação dos canais de comunicação.

Como consequência dos fatores apontados acima e conforme abordado por Reichheld (1996), ficou mais difícil conquistar novos clientes, o que ocasiona maior custo de aquisição devido a mais promoções, brindes, descontos, comunicação, etc. Por esta razão, é primordial cuidar dos clientes atuais. $\mathrm{O}$ autor citado apresenta fatos que sustentam a afirmativa:

- O custo para conquistar novos clientes é pelo menos cinco vezes maior que o custo para manter clientes existentes;

- A perda média anual de clientes é de aproximadamente $10 \%$ nos principais mercados; se as organizações conseguissem elevar em apenas $5 \%$ sua retenção de clientes, poderiam aumentar seus lucros em até $100 \%$;

- Cerca de $20 \%$ dos clientes atuais representam $80 \%$ do faturamento ou da rentabilidade de uma organização (Regra de Pareto);

- A taxa de rentabilidade de um cliente tende a aumentar ao longo de sua vida como cliente retido, correspondendo ao valor do cliente ao longo tempo, definido por Rust et al. (2004) como CLV - Customer Life-time Value ou Valor Vitalício do Cliente. Ou seja, a soma de todos os valores gastos pelo cliente ao longo de sua vida de consumo na organização.

Neste cenário, a estratégia de gestão de clientes surge como uma forma das organizações obterem vantagem competitiva sobre seus concorrentes, permitindo a entrega de produtos e a 
prestação de serviços mais qualificados. Peppers e Rogers $(2001$; 2004) relatam algumas características desta estratégia:

- Objetiva aquisição, fidelização e rentabilização da base de clientes;

- Procura manter o relacionamento a longo prazo;

- Considera o valor, o comportamento e as necessidades dos clientes;

- Foca nos clientes de maior valor para a organização;

- Pressupõe permissão, pertinência e interatividade na comunicação;

- Comunica-se de forma segmentada, dirigida e personalizada;

- Utiliza principalmente canais de marketing direto e marketing digital;

- Permite a mensuração dos resultados e cálculo de ROI;

- Orienta-se por banco de dados (Database Marketing).

Dessa forma, a estratégia baseia-se no desenvolvimento de uma relação profunda com os clientes, que se daria por meio de um maior conhecimento e entendimento de seus comportamentos e necessidades destes, e de entrega de interações e experiências relevantes e personalizadas, constituindo um vínculo de aprendizado entre a organização e seus clientes (PEPPERS; ROGERS, 2001). Como resultado, espera-se obter maior participação nos gastos de cada cliente individual (customer share) e, por consequência, conseguir maior participação no mercado como um todo (market share).

A tecnologia da informação e de processos de produção, cada vez mais barata e acessível (VAVRA, 1993), também contribuiu para o crescimento desta estratégia, com a possibilidade de armazenamento e acesso a grande quantidade de dados sobre os clientes, customização em massa de produtos e serviços, e interação personalizada com os clientes (GORDON, 1998; MCKENNA, 1992).

O uso das práticas de gestão de clientes foi mais acelerado nos setores de serviços recorrentes, como os de assinaturas de periódicos (revistas e jornais), telecomunicações (telefonia, internet e TV por assinatura) e financeiro (bancos, seguradoras e cartões de crédito); essa estratégia também foi adotada naqueles de recompra frequente, como o setor de turismo (hotéis e companhias aéreas). São serviços nos quais é necessário a identificação individual para relação 
com o prestador (inseparabilidade), o que facilita o desenvolvimento do relacionamento entre as partes (BERRY, 1995).

Nestes mercados, os custos de mudança de marca estão cada vez menores para o consumidor, ou seja, os clientes têm mais facilidade para mudar de provedor, tanto pelo aumento da oferta das organizações, quanto por proteção da legislação, como é o caso da portabilidade nos mercados de telefonia e bancário. Além desses fatores, ainda há a questão do maior acesso a canais de venda e comparadores de preço, no caso do comércio eletrônico.

Dada a facilidade e a pré-disposição que os clientes tem para mudar de fornecedor, um grande desafio é criar barreiras de mudança que não sejam apenas racionais, mas também emocionais. Para tanto, as empresas precisam intensificar o relacionamento com seus clientes, de forma a obter maior conhecimento e estabelecer interações relevantes e personalizadas nos pontos de contato (PEPPERS; ROGERS, 2001), o que também garante a tolerância a pequenas falhas.

Assim, como já exposto, a gestão de clientes pode ser vista como uma orientação estratégica para toda a organização, com foco na captura, entendimento e atendimento das necessidades e desejos dos clientes - principal stakeholder da organização (DAY, 2001) - visando criar uma relação contínua de aprendizado com o público de maior valor (PEPPERS; ROGERS, 2001).

Para Payne e Frow (2005), a gestão de clientes é uma abordagem estratégica preocupada com a criação de valor para os acionistas por meio do desenvolvimento de relacionamentos apropriados com clientes chave e com os segmentos de clientes. De forma complementar, Martin (2010) demonstra que as organizações podem alavancar o valor para os acionistas em médio e longo prazo, se forem orientadas aos seus clientes e focarem na maximização da satisfação destes em seus planos de curto prazo.

Em relação aos objetivos de negócios, a estratégia de gestão de clientes está ligada à aquisição (ou conquista), fidelização (ou manutenção) e desenvolvimento (ou rentabilização) da base de clientes ao longo do tempo (BARRETO; CRESCITELLI, 2008). Estes dois últimos objetivos explicam o aumento do valor vitalício do cliente (CLV).

Uma característica vantajosa da gestão de clientes é justamente a capacidade de mensuração destes resultados. Do ponto de vista de marketing, segundo Verhoef e Leeflang (2009), as 
estratégias podem perder espaço nas organizações se não tiverem a capacidade de relacionar as iniciativas com indicadores de desempenho financeiro. Existe uma crença geral de que as ações de marketing não trazem valor para as organizações (BOULDING et al., 2005). Para aumentar a accountability, sugerem-se estudos que examinem mais diretamente o impacto no valor ao acionista, o que complementa a visão de Martin (2010) sobre a avaliação do retorno a partir da satisfação de clientes a longo prazo. A gestão de clientes atende a este propósito.

Para atingir os objetivos de gestão de clientes, de bastante forma prática, Peppers e Rogers (1993; 2001) recomendam a implementação de iniciativas para:

- Promover o conhecimento da base de clientes (identificação individual e diferenciação por valor, comportamento e necessidades); e,

- Melhorar a experiência dos clientes, com foco nos mais valiosos (interação nos pontos de contato e personalização de produtos e serviços).

Já na visão de Payne e Frow (2005), a gestão de clientes é baseada em cinco processos principais: desenvolvimento da estratégia, criação de valor, integração multicanal, gestão da informação e avaliação de desempenho. Os autores desenvolveram um framework conceitual para CRM, baseado nestes processos, que permite entender seus aspectos e seu papel no aumento do valor para o cliente. Como resultado, isso gera aumento do valor para o acionista:

- Desenvolvimento da estratégia: Baseia-se num diagnóstico da estratégia de negócios, começando pelo propósito da organização e passando pela análise do ambiente competitivo, e alinhamento e integração com a estratégia de clientes. Normalmente a estratégia de negócios é de responsabilidade da alta direção ou diretoria de planejamento, enquanto que a estratégia de clientes está sob responsabilidade do marketing. Embora tenha uma abordagem multidisciplinar com envolvimento de várias áreas da organização, com base em regras de negócios que envolvem principalmente marketing e TI. A estratégia de clientes envolve o conhecimento da base de clientes atual e potencial, bem como o entendimento de seus perfis e características, e a identificação de formas de segmentação mais apropriadas em diversos níveis; considerando que existe a possibilidade de se desenvolver subsegmentos, saindo de uma visão de mercado de massa para uma visão individual (Marketing 1to1). Os canais digitais, como o e-commerce, permitem uma granularidade de segmentação muito mais profunda; 
- Criação de valor: Entendimento do processo de criação de valor para o cliente, por meio da definição de proposta de valor para o cliente e do resultado financeiro para a organização, em um processo de cocriação, baseado na análise dos segmentos por valor do cliente ao longo do tempo (life-time value);

- Integração multicanal: Integração e gestão dos pontos de contato com o cliente, canais físicos ou virtuais, como força de vendas, lojas, call center, marketing direto, e-commerce, mobile, redes sociais, etc.;

- Gestão da informação: Os demais processos são suportados por repositórios de dados de clientes, suportados por sistemas da informação, ferramentas de análise, aplicações de operação de "linha de frente" (front-end) e de suporte (back-office);

- Avaliação de desempenho: Avaliação dos resultados, por meio do valor gerado aos clientes, consumidores e acionistas, e redução de custos. Monitoramento de performance, como padrões de qualidade definidos, métricas quantitativas e qualitativas, resultados e indicadores de performance (KPIs). 


\section{MÉTODO DE PESQUISA}

Neste tópico, o método utilizado na pesquisa empírica será detalhado e discutido, visando, a partir e de forma complementar ao relato e à revisão teórica, alcançar os objetivos propostos.

Por meio do presente estudo, pretende-se identificar e compreender as diretrizes para implementação da estratégia de gestão de clientes nas organizações de varejo em ambiente multicanal, bem como analisar desafios, restrições, oportunidades e melhores práticas.

Com base no relato empírico da experiência prática e no referencial teórico estudado, algumas hipóteses foram levantadas para nortear o processo de pesquisa:

(i) O varejo brasileiro está vivenciando um grande processo de transformação, como nunca visto antes. Estas mudanças incluem o desenvolvimento de cenário altamente competitivo, com fortalecimento da tendência de atuação multicanal, juntamente com o surgimento de novas tecnologias e mudanças no comportamento dos consumidores;

(ii) Diante deste cenário, existe a oportunidade de criar diferenciais competitivos por meio de estratégia de gestão do relacionamento com clientes, como ocorre em outros setores;

(iii) No entanto, há a necessidade de adaptação dos métodos e práticas para implementação da estratégia no varejo em ambiente multicanal, considerando a complexidade do setor e as características das organizações.

No processo de desenvolvimento do trabalho, foram cobertas as seguintes etapas:

- Levantamento de informações de mercado em fontes secundárias, como indicadores e pesquisas disponíveis, visando compreender o tamanho e as características do varejo multicanal, bem como entender as mudanças no comportamento do consumidor e as novas tecnologias para conhecimento e interação com clientes;

- Análise comparativa entre a prática relatada, as informações de mercado e as teorias existentes (referencial teórico) para definição final dos temas e roteiro de pesquisa;

- Pesquisa empírica para aprofundamento das temáticas e validação da análise realizada, a partir de metodologia que considere os objetivos e as restrições para execução do trabalho; 
- Análise dos resultados buscando contribuições possíveis para a prática (interferir / aplicar nas organizações) e para a teoria (propor estudos e mudanças).

Para o levantamento de informações de mercado, foi realizada uma análise documental em fontes secundárias, como notícias em meios especializados, consultorias de negócios e entidades de classe, visando a apuração de indicadores, pesquisas e tendências de mercado.

A análise comparativa entre o relato empírico da experiência, as informações de mercado levantadas e o referencial teórico, permitiu um maior conhecimento e compreensão sobre os temas e objetivos do estudo, fator esse que preparou o pesquisador para o desenvolvimento das etapas seguintes. Foram necessários cerca de seis meses para execução do projeto de pesquisa e conclusão do trabalho final, que teve sua realização entre fevereiro e julho de 2016.

\subsection{O Método da Pesquisa}

O método para a pesquisa empírica é exploratório e qualitativo, desenvolvido por meio de entrevistas em profundidade com profissionais especialistas no mercado de varejo (executivos e consultores) e através da utilização de técnicas de análise de conteúdo para procedimento analítico (BARDIN, 2009).

Segundo SELLTIZ et al. (1975 apud KHAUAJA, 2009), na pesquisa exploratória busca-se a maior compreensão de um problema ou familiarização com um novo fenômeno. Este método é adequado ao objetivo deste trabalho, visto que estratégias para o varejo multicanal é ainda um assunto novo e pouco explorado em pesquisas acadêmicas no Brasil. Por isso, o tema carece de maior conhecimento antes da formulação de hipóteses para pesquisas descritivas ou causais.

A pesquisa exploratória é caracterizada pela flexibilidade dos métodos de coleta de dados, com procedimentos menos estruturados que outros, porém com maior amplitude, riqueza e proximidade do objeto de estudo. Esta modalidade de pesquisa é bastante adequada para a avaliação qualitativa em projetos de ciências sociais aplicadas, permitindo estudar fenômenos de forma detalhada e profunda. 


\subsection{Seleção da Amostra}

Por se tratar de uma pesquisa exploratória, a amostragem foi não probabilística, ou seja, sem possibilidade de extrapolação estatística, e definida conforme a conveniência do pesquisador.

Foram considerados dois perfis de especialistas a serem entrevistados, ambos com concentração preferencial na cidade de São Paulo/SP, devido às questões de acessibilidade e atendimento ao prazo para execução da pesquisa de campo:

- Consultores: executivos ou profissionais de renomadas consultorias ou de prestadores de serviços de marketing, com experiência comprovada em estratégias e funções de gestão de clientes nos segmentos de serviços ou varejo com lojas físicas e/ou digitais;

- Executivos: diretores ou gerentes de marketing ou com funções de gestão de clientes em organizações de varejo multicanal, com lojas físicas e digitais.

A relação de potenciais entrevistados foi originada na rede de relacionamento (networking) do pesquisador, formada ao longo da sua carreira profissional, sendo posteriormente complementada por indicação de outros pós-graduandos ou dos próprios entrevistados. Como critério de seleção, foi estabelecido um parâmetro de pelo menos 10 anos de experiência no mercado de varejo, aliado à vivência em organizações e/ou consultorias em cargos de gestão (diretoria ou gerência).

A meta era obter entre 10 a 12 entrevistas, sendo metade para cada perfil de especialista. Ao final, foi possível obter 13 entrevistas, sendo 7 executivos e 6 consultores. As tabelas a seguir ilustram o perfil dos especialistas entrevistados. 
Tabela 1 - Perfil e segmentos da amostra

\begin{tabular}{|c|r|r|}
\hline Perfil e Segmento & \# & \multicolumn{1}{c|}{$\%$} \\
\hline Executivos de Varejo & $\mathbf{7}$ & $\mathbf{5 3 , 8 \%}$ \\
\hline Moda & 3 & $42,9 \%$ \\
\hline Cosméticos & 1 & $14,3 \%$ \\
\hline Eletroeletrônicos & 1 & $14,3 \%$ \\
\hline Livros & 1 & $14,3 \%$ \\
\hline Supermercados & 1 & $14,3 \%$ \\
\hline Consultores de Varejo & $\mathbf{6}$ & $\mathbf{4 6 , 2 \%}$ \\
\hline Estratégia & 3 & $50,0 \%$ \\
\hline E-commerce & 1 & $16,7 \%$ \\
\hline Pesquisa & 1 & $16,7 \%$ \\
\hline Tecnologia & 1 & $16,7 \%$ \\
\hline Total de Entrevistados & $\mathbf{1 3}$ & $\mathbf{1 0 0 , 0 \%}$ \\
\hline
\end{tabular}

Fonte: Elaborado pelo autor.

Os executivos entrevistados estão distribuídos em diversos segmentos, sendo que três são do setor de varejo de moda. Em relação aos consultores de varejo, três são focados em estratégia e inteligência, e os demais em segmentos mais específicos de consultoria.

Tabela 2 - Tempo de experiência dos entrevistados

\begin{tabular}{|l|r|c|}
\hline Tempo de Experiência & \# & \multicolumn{1}{c|}{$\%$} \\
\hline $14-16$ anos & 6 & $46,2 \%$ \\
\hline $18-20$ anos & 5 & $38,5 \%$ \\
\hline 30 anos & 2 & $15,4 \%$ \\
\hline Total de Entrevistados & $\mathbf{1 3}$ & $\mathbf{1 0 0 , 0 \%}$ \\
\hline
\end{tabular}

Fonte: Elaborado pelo autor.

Nota-se que são profissionais com muito tempo de atuação no mercado, com pelo menos 14 anos de experiência e média de quase 19 anos. É importante destacar que boa parte dessa vivência foi adquirida no setor de varejo.

No quadro a seguir, por ordem alfabética de nome, pode-se verificar as informações de cada um dos entrevistados, sendo que 3 deles são executivos de varejo de moda de organizações diferentes e não autorizaram a divulgação dos dados de identificação. Dentre as informações, 
constam o perfil, cargo ocupado, segmento de varejo ou consultoria, e tempo de experiência profissional.

Quadro 1 - Informações dos especialistas entrevistados

\begin{tabular}{|c|c|c|c|c|c|}
\hline Perfil & Nome & Cargo & Organização & Segmento & Tempo \\
\hline Executivo & Adílson Rielo & $\begin{array}{c}\text { Gerente de } \\
\text { E-commerce }\end{array}$ & Saraiva Livraria & $\begin{array}{l}\text { Varejo de } \\
\text { Livros }\end{array}$ & 15 anos \\
\hline Consultor & Alexandre van Beeck & $\begin{array}{l}\text { Sócio } \\
\text { Diretor }\end{array}$ & Gouvêa de Souza & $\begin{array}{l}\text { Consultoria de } \\
\text { Estratégia }\end{array}$ & 20 anos \\
\hline Executivo & Celso Furtado & $\begin{array}{l}\text { Gerente de } \\
\text { Negócios }\end{array}$ & $\begin{array}{c}\text { Coop - Cooperativa } \\
\text { de Consumo }\end{array}$ & $\begin{array}{c}\text { Varejo de } \\
\text { Supermercados }\end{array}$ & 20 anos \\
\hline Consultor & Fátima Merlin & $\begin{array}{l}\text { Sócia } \\
\text { Diretora }\end{array}$ & Connect Shopper & $\begin{array}{l}\text { Consultoria de } \\
\text { Estratégia }\end{array}$ & 30 anos \\
\hline Consultor & João Bernartt & $\begin{array}{l}\text { Diretor } \\
\text { Presidente }\end{array}$ & Linx Chaordic & $\begin{array}{l}\text { Tecnologia de } \\
\text { Varejo }\end{array}$ & 14 anos \\
\hline Executivo & Karina Oliveira & $\begin{array}{l}\text { Gerente de } \\
\text { CRM }\end{array}$ & Magazine Luiza & $\begin{array}{l}\text { Varejo de } \\
\text { Eletroeletrônicos }\end{array}$ & 16 anos \\
\hline Executivo & Murillo Boccia & $\begin{array}{c}\text { Diretor de } \\
\text { E-commerce }\end{array}$ & Natura & $\begin{array}{l}\text { Varejo de } \\
\text { Cosméticos }\end{array}$ & 20 anos \\
\hline Consultor & Olegário Araújo & $\begin{array}{l}\text { Sócio } \\
\text { Diretor }\end{array}$ & $\begin{array}{l}\text { Inteligência de } \\
\text { Varejo }\end{array}$ & $\begin{array}{l}\text { Consultoria de } \\
\text { Estratégia }\end{array}$ & 30 anos \\
\hline Consultor & Rafael Lindemeyer & $\begin{array}{l}\text { Diretor de } \\
\text { Negócios }\end{array}$ & Ipsos Brasil & $\begin{array}{l}\text { Instituto de } \\
\text { Pesquisa }\end{array}$ & 18 anos \\
\hline Consultor & Roberto Wajnsztok & $\begin{array}{l}\text { Sócio } \\
\text { Diretor }\end{array}$ & Origin5 & $\begin{array}{l}\text { Consultoria de } \\
\text { E-commerce }\end{array}$ & 14 anos \\
\hline Executivo & (não autorizado) & $\begin{array}{l}\text { Gerente de } \\
\text { Marketing }\end{array}$ & (não autorizado) & $\begin{array}{l}\text { Varejo de } \\
\text { Moda }\end{array}$ & 15 anos \\
\hline Executivo & (não autorizado) & $\begin{array}{l}\text { Gerente de } \\
\text { CRM }\end{array}$ & (não autorizado) & $\begin{array}{l}\text { Varejo de } \\
\text { Moda }\end{array}$ & 14 anos \\
\hline Executivo & (não autorizado) & $\begin{array}{l}\text { Diretora de } \\
\text { Marketing }\end{array}$ & (não autorizado) & $\begin{array}{l}\text { Varejo de } \\
\text { Moda }\end{array}$ & 20 anos \\
\hline
\end{tabular}

Fonte: Elaborado pelo autor.

\subsection{Coleta de Dados}

O método escolhido para coleta de dados, deve estar adequado aos objetivos da pesquisa e às condições nas quais ela se realiza (YIN, 2001 apud KHAUAJA, 2009). Neste trabalho, foi utilizada a entrevista em profundidade baseada em um roteiro semiestruturado, que permite ao pesquisador flexibilidade para ordenar e reformular as questões durante a entrevista, com o devido cuidado para que as respostas do entrevistado sejam espontâneas, naturais, específicas e concretas. 
A comunicação foi dual (diálogo), por meio de entrevista oral, realizada pessoalmente, por telefone ou por comunicador de voz via Internet (Skype), de acordo com a disponibilidade e conveniência do entrevistado. As entrevistas foram realizadas ao longo dos meses de maio, junho e julho de 2016, com duração entre 1 h00 e 1h30 cada. A experiência do autor em entrevistas em profundidade para diagnóstico de consultoria estratégica foi considerada importante para a boa fluidez das conversas, gestão do tempo e utilização flexível do roteiro.

Os tópicos do roteiro semiestruturado foram definidos com base no relato da experiência do autor, informações de mercado e revisão teórica. A primeira entrevista serviu como pré-teste do questionário, que foi validado e ajustado para as próximas. No Apêndice A deste trabalho, encontra-se o roteiro completo utilizado nas entrevistas, composto por 7 categorias temáticas, sendo as três primeiras sobre o Varejo Multicanal e Omnichannel, e as quatro últimas relativas aos principais Processos de Gestão de Clientes.

Nos quadros a seguir estão listadas as categorias e seus respectivos temas.

\section{Quadro 2 - Categorias e temas de Varejo Multicanal e Omnichannel}

\begin{tabular}{|c|c|}
\hline Categorias & Temas \\
\hline \multirow{2}{*}{$\begin{array}{l}\text { Cenário Competitivo do } \\
\text { Varejo Brasileiro }\end{array}$} & T1 - Desafios do Ambiente Externo \\
\hline & T2 - Desafios do Ambiente Interno \\
\hline \multirow{2}{*}{$\begin{array}{c}\text { Mudanças no } \\
\text { Comportamento } \\
\text { dos Consumidores }\end{array}$} & $\begin{array}{l}\text { T3 - Mudanças Motivadas pela } \\
\text { Evolução Tecnológica }\end{array}$ \\
\hline & $\begin{array}{l}\text { T4 - Necessidades e Atitudes em } \\
\text { Relação ao Consumo }\end{array}$ \\
\hline \multirow{4}{*}{$\begin{array}{l}\text { Características e Integração } \\
\text { do Varejo Multicanal }\end{array}$} & T5 - Principais Canais e Tendências \\
\hline & T6 - Integração e Conflito de Canais \\
\hline & $\begin{array}{l}\text { T7 - Preparação e Principais } \\
\text { Dificuldades das Organizações }\end{array}$ \\
\hline & T8 - Casos e Melhores Práticas \\
\hline
\end{tabular}

Fonte: Elaborado pelo autor. 


\section{Quadro 3 - Categorias e temas de Processos de Gestão de Clientes}

\begin{tabular}{|c|c|}
\hline \multirow{3}{*}{$\begin{array}{c}\text { Processo de } \\
\text { Desenvolvimento } \\
\text { da Estratégia }\end{array}$} & $\begin{array}{l}\text { T9 - Alinhamento com Estratégia e } \\
\text { Objetivos Organizacionais }\end{array}$ \\
\hline & $\begin{array}{l}\text { T10 - Envolvimento na Estratégia de } \\
\text { Gestão de Clientes }\end{array}$ \\
\hline & $\begin{array}{l}\text { T11 - Principais Mudanças e } \\
\text { Impactos nas Organizações }\end{array}$ \\
\hline \multirow{2}{*}{$\begin{array}{c}\text { Processo de } \\
\text { Gestão da Informação / } \\
\text { Conhecimento dos Clientes }\end{array}$} & $\begin{array}{l}\text { T12 - Captura de Dados e Criação de } \\
\text { Visão Única }\end{array}$ \\
\hline & $\begin{array}{l}\text { T13 - Análises e Segmentação da } \\
\text { Base de Consumidores }\end{array}$ \\
\hline \multirow{3}{*}{$\begin{array}{c}\text { Processo de } \\
\text { Criação de Valor / } \\
\text { Experiência dos Clientes }\end{array}$} & $\begin{array}{l}\text { T14 - Planos de Interação com } \\
\text { Segmentos de Consumidores }\end{array}$ \\
\hline & $\begin{array}{l}\text { T15 - Desenho de Programas de } \\
\text { Relacionamento / Fidelidade }\end{array}$ \\
\hline & $\begin{array}{l}\text { T16 - Personalização de Produtos, } \\
\text { Serviços e Interações }\end{array}$ \\
\hline \multirow{2}{*}{$\begin{array}{l}\text { Processo de Avaliação de } \\
\text { Desempenho e Resultados }\end{array}$} & $\begin{array}{l}\text { T17 - Métricas de Desempenho e } \\
\text { Avaliação de Resultados }\end{array}$ \\
\hline & $\begin{array}{l}\text { T18 - Resultados e Criação de Valor } \\
\text { para Acionistas }\end{array}$ \\
\hline
\end{tabular}

Fonte: Elaborado pelo autor.

Antes de iniciar a entrevista, o pesquisador buscou estabelecer uma relação menos formal com entrevistados. Por isso, agradeceu a disponibilidade, apresentou brevemente seus antecedentes profissionais e acadêmicos, e esclareceu a linha de pesquisa e o programa de mestrado profissional. Depois, o pesquisador fez uma breve explanação sobre os objetivos e motivações do projeto de pesquisa, bem como sobre os processos de escolha dos entrevistados e estratégia de pesquisa de campo com roteiro semiestruturado. Na sequência, fez alinhamento do tempo disponível e solicitou autorização para gravação, obtendo a concordância de todos.

Ainda nas preliminares, o pesquisador reforçou que as respostas deveriam ser dadas conforme a visão de profissional atuante no setor, pensando nas empresas ou projetos que participa ou participou, sempre pela ótica do varejista (não da indústria de bens de consumo), de qualquer segmento de varejo, considerando as organizações brasileiras de médio e grande porte. 
Na sequência, o pesquisador fez um alinhamento dos conceitos abordados na entrevista, por meio de apresentação de "fichas" com a descrição resumida dos temas principais (unidades de pesquisa): Varejo Multicanal, Consumidor Omnichannel e Gestão de Clientes. Os conceitos apresentados dos temas de pesquisa podem ser verificados no Apêndice B deste trabalho.

Para começar a entrevista, foi solicitado ao especialista uma breve explicação da experiência profissional e seu tempo de trabalho nas áreas de varejo e gestão de clientes (CRM).

Na primeira parte da entrevista, conforme o roteiro, a ideia foi obter uma visão do cenário do varejo multicanal, seus desafios, ameaças e oportunidades nos ambientes externo e interno à organização, incluindo as mudanças no comportamento e surgimento de novas tecnologias. Depois, foi abordado o entendimento sobre varejo multicanal, suas características, tendências, integração, conflitos, nível de preparação das organizações, casos e melhores práticas.

Na segunda parte da entrevista, uma vez entendido o cenário do varejo multicanal pela ótica do entrevistado, o pesquisador explorou o tema da adequação da estratégica de gestão de clientes ao contexto e a implementação dos principais processos, como o desenvolvimento da estratégia, gestão de conhecimento, criação de valor e gestão da experiência dos clientes, e avaliação de desempenho da estratégia.

Durante as entrevistas, o pesquisador anotou os trechos mais relevantes, conforme os temas definidos, e gravou todas as conversas para análise posterior e recuperação das respostas. Também procurou, quando possível, intercalar a ordem dos temas de pesquisa das categorias em cada entrevista, visando evitar um viés de cansaço e, consequentemente, o prejuízo a respostas de temas específicos.

\subsection{Procedimentos Analíticos}

A qualidade da análise dos dados qualitativos depende não só da experiência do pesquisador sobre o objeto de pesquisa, mas também das técnicas e procedimentos analíticos utilizados, visto que estes ajudam a minimizar qualquer direcionamento de interpretação. 
Para este estudo, foram utilizados como referência os procedimentos de análise de conteúdo preconizados por Bardin (2009). Segundo a autora, a análise de conteúdo é um "conjunto de técnicas de análise das comunicações" que busca, por meio de "procedimentos sistemáticos e objetivos de descrição do conteúdo das mensagens", conseguir indicadores quantitativos ou qualitativos que permitam a replicação e "inferência de conhecimentos relativos às condições de produção e recepção das mensagens".

É, portanto, um método empírico que depende do tipo de comunicação e do tipo do resultado esperado. Bardin (2009) recomenda que a análise de conteúdo seja desenvolvida em 3 fases consideradas neste estudo na seguinte ordem: 1) Pré-análise do material; 2) Exploração do material; 3) Tratamento dos resultados e interpretação. A figura a seguir resume as 3 etapas de análise de conteúdo consideradas neste trabalho.

Figura 6 - Desenvolvimento de análise de conteúdo

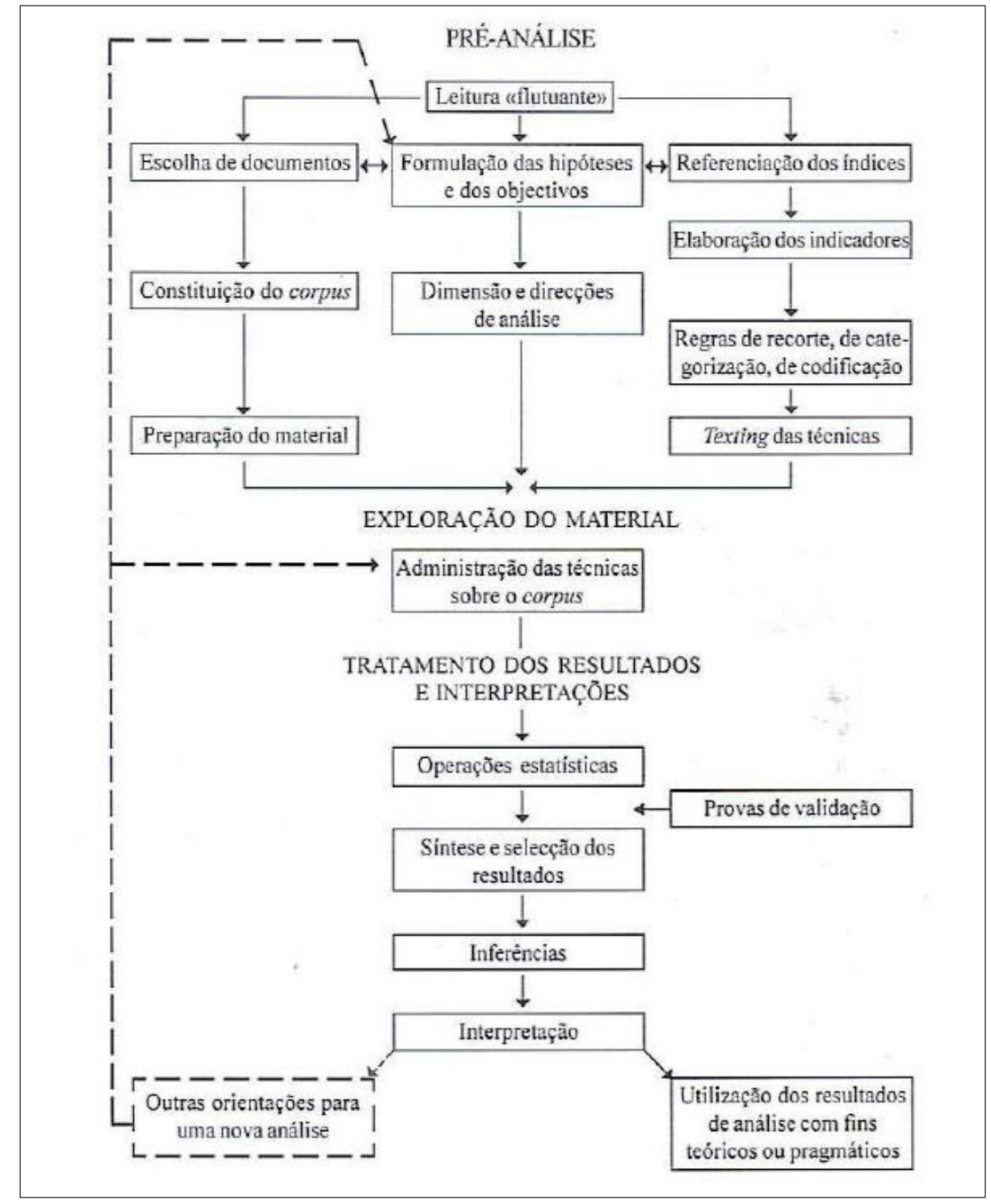

Fonte: Bardin (2009, p. 128). 
Na fase de pré-análise, o material da pesquisa é preparado e organizado para uso nas fases seguintes. Ela envolve a descrição ou transcrição das entrevistas, a eliminação de trechos não necessários, como conversas dispersas, abertura e fechamento, a formulação ou confirmação das hipóteses e objetivos da pesquisa, o referenciamento dos índices (temas), a determinação de indicadores (recortes de texto), as dimensões e direções de análise, as regras de recorte / categorização e o teste das técnicas. O objetivo é preparar um documento final para exploração, a partir da sistematização dos dados iniciais e do desenvolvimento de um plano de análise.

Durante presente estudo, na fase de pré-análise, o pesquisador partiu de uma lista de unidades de análise pré-definidas após reflexão sobre o relato da experiência e o referencial teórico, que serviram como base para a elaboração do roteiro semiestruturado. As anotações realizadas durante as entrevistas foram revistas, para ajustes de texto e eliminação de trechos desnecessários ao objetivo da pesquisa. O pesquisador também fez uso das gravações para complementar ou recuperar trechos específicos.

Com os documentos das entrevistas revisados, o pesquisador fez a leitura individual flutuante, como recomendado por Bardin (2009), “deixando-se invadir por impressões e orientações", visando absorver as informações coletadas para cada tema definido a priori, e ratificar as hipóteses e objetivos da pesquisa.

Os índices finais (temas) foram ajustados após esta leitura atenta. Então, foram encontrados os indicadores (proposições) nos documentos de cada entrevista, correspondentes a cada tema definido. Para serem escolhidas, as proposições deveriam ter sido citadas por pelo menos dois entrevistados distintos, pois isso permitia o seu "encaixe" nos temas. Por fim, foi preparado um material único e final com todas as respostas encontradas para cada tema definido, ficando pronto o documento para exploração na fase seguinte.

Na fase de exploração, Bardin (2009) recomenda a aplicação de técnicas para codificação do material preparado, ou seja, a definição das unidades de registro e identificação das unidades de contexto. O objetivo desse procedimento é a definir os sistemas de categorias e contagens para classificação do material, disponibilizando os dados para tratamento e interpretação na etapa seguinte. 
A unidade de registro é o segmento de conteúdo que será codificado como uma unidade base, visando a categorização e a contagem de frequência. Ele poderá constituir-se de uma palavra ou tema dentro do texto. A unidade de contexto, por sua vez, é o segmento da mensagem que serve de compreensão para codificar a unidade de registro e compreender o seu significado. Ela pode ser uma frase ou resposta completa para uma pergunta aberta.

Para definir o sistema de categorias, é preciso elaborar uma regra de contagem (enumeração). Em um conjunto de textos, calcula-se a frequência dos elementos desejados, numa abordagem quantitativa que pode suportar a análise qualitativa (inferências). Após a contagem, é possível definir os grupos de unidades de registros, com características comuns, que irão formar cada categoria sob um título genérico, completando a operação de classificação dos elementos, ou seja, de organização das mensagens.

No presente estudo, durante a fase de exploração, a identificação das categorias foi baseada no relato da experiência do pesquisador, no referencial teórico e na análise dos dados da pesquisa, por meio de avaliação progressiva dos elementos do texto. A categorização usada foi semântica, ou seja, baseou-se em categorias temáticas com algum significado. Assim, o critério para definição das categorias e temas é considerado como misto, pois parte de análises e reflexões antes da pesquisa empírica e é ajustado após a realização e análise da mesma (Bardin, 2009).

Para a definição final dos sistemas de categorias, o pesquisador utilizou algumas técnicas na fase de exploração. Primeiro, foram ratificadas unidades de registro (temas) para classificação e enumeração. Por sua vez, estas foram evidenciadas em mensagens das unidades de contexto (proposições) por meio de frases ou citações identificadas nas respostas do documento. Depois, foram definidas as regras de contagem das unidades de registro: quantidade de vezes que os temas e proposições foram abordados pelo entrevistado, ou seja, contagem das unidades de contexto (indicadores).

A classificação final do material foi representada por meio de tabelas com as contagens dos indicadores dos temas e respectivas proposições, além do total de entrevistados únicos que emitiram as frases ou citações. Por fim, partindo das tabelas, foram analisadas as diferenças e agrupamentos de respostas dos especialistas, em processo de análise progressiva de elementos do texto, culminando nas categorias para interpretação na fase seguinte (Bardin, 2009). 
Os quadros a seguir demonstram as categorias, temas e proposições finais definidos após os procedimentos de análise de conteúdo, compondo sistemas de categorias referentes a Varejo Multicanal / Omnichannel e Processos de Gestão de Clientes.

Quadro 4 - Sistemas de categorias de Varejo Multicanal e Omnichannel

\begin{tabular}{|c|c|c|}
\hline Categorias & Temas & Proposições \\
\hline \multirow{8}{*}{$\begin{array}{l}\text { Cenário Competitivo } \\
\text { do Varejo Brasileiro }\end{array}$} & \multirow{3}{*}{$\begin{array}{l}\text { T1 - Desafios do } \\
\text { Ambiente Externo }\end{array}$} & T1.P1 - Crise Econômica Brasileira \\
\hline & & T1.P2 - Surgimento de Novas Tecnologias \\
\hline & & T1.P3 - Aumento da Concorrência \\
\hline & \multirow{5}{*}{$\begin{array}{l}\mathrm{T} 2 \text { - Desafios do } \\
\text { Ambiente Interno }\end{array}$} & T2.P1 - Gestão Estratégica e Governança \\
\hline & & T2.P2 - Gestão de Finanças e Recursos \\
\hline & & T2.P3 - Atendimento e Serviços ao Consumidor \\
\hline & & T2.P4 - Monitoramento e Inteligência de Mercado \\
\hline & & T2.P5 - Gestão de Produtos, Estoques e Logística \\
\hline \multirow{7}{*}{$\begin{array}{l}\text { Mudanças no } \\
\text { Comportamento dos } \\
\text { Consumidores }\end{array}$} & \multirow{2}{*}{$\begin{array}{l}\text { T3 - Mudanças Motivadas } \\
\text { pela Evolução Tecnológica }\end{array}$} & T3.P1 - Maior Conectividade e Mobilidade \\
\hline & & T3.P2 - Maior Acesso a Informações \\
\hline & \multirow{5}{*}{$\begin{array}{l}\text { T4 - Necessidades e Atitudes } \\
\text { em Relação ao Consumo }\end{array}$} & T4.P1 - Busca por Praticidade e Conveniência \\
\hline & & T4.P2 - Busca por Melhor Experiência de Consumo \\
\hline & & T4.P3 - Fatores Sócio Demográficos \\
\hline & & T4.P4 - Orientação pela Jornada de Compra \\
\hline & & T4.P5 - Responsabilidade Sócio Ambiental \\
\hline \multirow{22}{*}{$\begin{array}{c}\text { Características e } \\
\text { Integração do Varejo } \\
\text { Multicanal }\end{array}$} & \multirow{5}{*}{$\begin{array}{l}\text { T5 - Principais Canais } \\
\text { e Tendências }\end{array}$} & T5.P1 - E-commerce / Canais Digitais (On-line) \\
\hline & & T5.P2 - Canais Tradicionais (Off-line) \\
\hline & & T5.P3 - Dispositivos Móveis (Mobile) \\
\hline & & T5.P4 - Tendências e Novos Canais \\
\hline & & T5.P5 - Redes Sociais (Social Media) \\
\hline & \multirow{4}{*}{$\begin{array}{l}\text { T6 - Integração e } \\
\text { Conflito de Canais }\end{array}$} & T6.P1 - Política de Preços e Promoções \\
\hline & & T6.P2 - Informações de Produtos e Ofertas \\
\hline & & T6.P3 - Objetivos, Metas e Incentivos \\
\hline & & T6.P4 - Comunicação e Campanhas de Marketing \\
\hline & \multirow{7}{*}{$\begin{array}{l}\text { T7 - Preparação e Principais } \\
\text { Dificuldades das Organizações }\end{array}$} & T7.P1 - Diretrizes e Objetivos Estratégicos \\
\hline & & T7.P2 - Estrutura e Recursos Organizacionais \\
\hline & & T7.P3 - Gestão de Inovação e Tecnologia \\
\hline & & T7.P4 - Gestão de Processos de Negócios \\
\hline & & T7.P5 - Gestão de Pessoas e Cultura Organizacional \\
\hline & & T7.P6 - Gestão de Estoques e Logística \\
\hline & & T7.P7 - Legislação e Gestão Tributária \\
\hline & \multirow{6}{*}{ T8 - Casos e Melhores Práticas } & T8.P1 - Magazine Luíza \\
\hline & & T8.P2 - Grupo Pão de Açúcar \\
\hline & & T8.P3 - Livraria Saraiva \\
\hline & & T8.P4 - Natura Cosméticos \\
\hline & & T8.P5 - Outros Casos Nacionais \\
\hline & & T8.P6 - Casos Internacionais \\
\hline
\end{tabular}

Fonte: Elaborado pelo Autor. 


\section{Quadro 5 - Sistemas de categorias de Processos de Gestão de Clientes}

\begin{tabular}{|c|c|c|}
\hline Categorias & Temas & Proposições \\
\hline \multirow{19}{*}{$\begin{array}{c}\text { Processo de } \\
\text { Desenvolvimento } \\
\text { da Estratégia }\end{array}$} & \multirow{6}{*}{$\begin{array}{l}\text { T9 - Alinhamento c/ Estratégia } \\
\text { e Objetivos Organizacionais }\end{array}$} & T9.P1 - Gestão de Clientes como Estratégia de Negócios \\
\hline & & T9.P2 - Estratégia para Experiência dos Clientes \\
\hline & & T9.P3 - Estratégia para Conhecimento dos Clientes \\
\hline & & T9.P4 - Estratégia para Potencializar o Multicanal \\
\hline & & T9.P5 - Objetivos de Receita e Rentabilização \\
\hline & & T9.P6 - Objetivos de Satisfação e Fidelização \\
\hline & \multirow{7}{*}{$\begin{array}{c}\text { T10 - Envolvimento na } \\
\text { Estratégia de Gestão de } \\
\text { Clientes }\end{array}$} & T10.P1 - Liderança da Presidência / Alta Direção \\
\hline & & T10.P2 - Liderança de Marketing \\
\hline & & T10.P3 - Envolvimento de Marketing \\
\hline & & T10.P4 - Liderança de CRM e Inteligência de Mercado \\
\hline & & T10.P5 - Envolvimento de Tecnologia da Informação \\
\hline & & T10.P6 - Envolvimento de Comercial, Oper. e Logística \\
\hline & & T10.P7 - Envolvimento de Recursos Humanos \\
\hline & \multirow{6}{*}{$\begin{array}{l}\text { T11 - Principais Mudanças e } \\
\text { Impactos nas Organizações }\end{array}$} & T11.P1 - Gestão de Pessoas e Cultura Organizacional \\
\hline & & T11.P2 - Gestão de Tecnologia da Informação \\
\hline & & T11.P3 - Gestão de Processos de Negócios \\
\hline & & T11.P4 - Governança / Gestão de Indicadores (KPIs) \\
\hline & & T11.P5 - Estrutura e Recursos Organizacionais \\
\hline & & T11.P6 - Gestão Analítica e Inteligência de Negócios \\
\hline \multirow{12}{*}{$\begin{array}{c}\text { Processo de } \\
\text { Gestão da Informação / } \\
\text { Conhecimento do } \\
\text { Cliente }\end{array}$} & \multirow{7}{*}{$\begin{array}{l}\text { T12 - Captura de Dados e } \\
\text { Criação de Visão Única }\end{array}$} & T12.P1 - Transações e Interações de Canais Digitais \\
\hline & & T12.P2 - Transações e Interações de Canais Físicos \\
\hline & & T12.P3 - Bases de Dados Desestruturados (Big Data) \\
\hline & & T12.P4 - Pesquisas com Clientes de Canais Físicos \\
\hline & & T12.P5 - Pesquisas com Clientes de Canais Digitais \\
\hline & & T12.P6 - Gestão de Base de Clientes por Terceiros \\
\hline & & T12.P7 - Dados de Programas de Relacion. / Fidelidade \\
\hline & \multirow{5}{*}{$\begin{array}{c}\text { T13 - Análises e Segmentação } \\
\text { da Base de Consumidores }\end{array}$} & T13.P1 - Segmentação Comportamental \\
\hline & & T13.P2 - Segmentação por Canais de Vendas \\
\hline & & T13.P3 - Modelos Preditivos de Comportamento \\
\hline & & T13.P4 - Segmentação por Valor de Consumo \\
\hline & & T13.P5 - Segmentação por Necessidades \\
\hline \multirow{12}{*}{$\begin{array}{c}\text { Processo de } \\
\text { Criação de Valor / } \\
\text { Experiência do Cliente }\end{array}$} & \multirow{5}{*}{$\begin{array}{l}\text { T14 - Planos de Interação com } \\
\text { Segmentos de Consumidores }\end{array}$} & T14.P1 - Gestão de Campanhas e Réguas de Relacion. \\
\hline & & T14.P2 - Relevância nas Interações e Campanhas \\
\hline & & T14.P3 - Planos de Interação nos Canais Físicos \\
\hline & & T14.P4 - Planos de Interação nos Canais Digitais \\
\hline & & T14.P5 - Política de Impactos / Disparos de Ações \\
\hline & \multirow{2}{*}{$\begin{array}{l}\text { T15 - Desenho de Programas } \\
\text { de Relacionamento / Fidelidade }\end{array}$} & T15.P1 - Gestão de Programas de Fidelidade Próprios \\
\hline & & T15.P2 - Participação em Programas de Terceiros \\
\hline & \multirow{5}{*}{$\begin{array}{c}\text { T16 - Personalização de } \\
\text { Produtos, Serviços e Interações }\end{array}$} & T16.P1 - Personalização de Canais de Vendas \\
\hline & & T16.P2 - Personalização de Ofertas de Produtos \\
\hline & & T16.P3 - Personalização de Processos de Atendimento \\
\hline & & T16.P4 - Personalização de Relacion. / Comunicação \\
\hline & & T16.P5 - Processo de Cocriação de Produtos e Serviços \\
\hline \multirow{13}{*}{$\begin{array}{l}\text { Processo de Avaliação } \\
\text { de Desempenho } \\
\text { e Resultados }\end{array}$} & \multirow{7}{*}{$\begin{array}{l}\text { T17 - Métricas de Desempenho } \\
\text { e Avaliação de Resultados }\end{array}$} & T17.P1 - Retorno de Campanhas de Relacionamento \\
\hline & & T17.P2 - Indicadores de Satisfação e Fidelização \\
\hline & & T17.P3 - Performance / Visão por Canais de Vendas \\
\hline & & T17.P4 - Performance / Visão por Segm. de Clientes \\
\hline & & T17.P5 - Indicadores de Vendas, Receita e Margem \\
\hline & & T17.P6 - Indicadores de Comportamento de Compra \\
\hline & & T17.P7 - Indicadores de Eficiência Oper. e Custos \\
\hline & \multirow{6}{*}{$\begin{array}{c}\text { T18 - Resultados e Criação de } \\
\text { Valor p/ Acionistas }\end{array}$} & T18.P1 - Aumento de Volume de Vendas e Receita \\
\hline & & T18.P2 - Geração de Experiência Multicanal \\
\hline & & T18.P3 - Criação de Diferencial Competitivo \\
\hline & & T18.P4 - Aumento de Margem / Rentabilidade \\
\hline & & T18.P5 - Geração de Conhecimento dos Clientes \\
\hline & & T18.P6 - Parceria com Fornecedores / Indústria \\
\hline
\end{tabular}

Fonte: Elaborado pelo Autor. 
Antes de seguir para a próxima fase, vale ratificar que as categorias definidas obedecem aos critérios ideais definidos por Bardin (2009):

- Exclusão mútua: os elementos não podem coexistir em duas ou mais divisões;

- Homogeneidade: só pode haver uma dimensão de análise em cada conjunto de categorias;

- Pertinência: a categoria tem que que estar adaptada ao material de análise e ao referencial;

- Objetividade e fidelidade: as diferentes partes devem ser codificadas da mesma maneira, mesmo sendo realizadas várias análises, ou seja, a subjetividade deve ser evitada com regras;

- Produtividade: conjunto definido de categorias que apresenta resultados férteis em inferências, dados exatos e novas hipóteses.

Na última fase da análise de conteúdo, que se refere ao tratamento dos resultados e interpretações, são realizadas operações estatísticas e elaboradas tabelas e sínteses para seleção de informações e resultados, com base na experiência do pesquisador / analista e do referencial teórico. Essa etapa é realizada visando fazer interpretações e gerar inferências válidas para contribuição teórica e prática, além de sugerir novos estudos.

Neste estudo, na fase final de tratamento dos resultados e interpretação das informações, foi realizada a análise das tabelas com estatísticas simples, bem como de documentos produzidos para identificação de tendências e hipóteses. Foram observadas as similaridades e diferenças em cada categoria de análise, adotando uma abordagem qualitativa para fazer as inferências.

No próximo capítulo, serão apresentadas as tabelas com as contagens das categorias e temas; elas estarão acompanhadas das interpretações e inferências realizadas sobre os resultados como produto dos procedimentos de análise de conteúdo. 


\section{ANÁLISE E RESULTADOS}

Neste capítulo, serão apresentados os resultados obtidos a partir dos procedimentos de análise de conteúdo das respostas às entrevistas em profundidade, conforme descrito anteriormente. A análise final observou categorias, temas, proposições e contagens dos indicadores, visando cobrir os objetivos do estudo e responder às hipóteses levantadas.

As análises foram divididas em duas partes: Varejo Multicanal e Omnichannel, e Processo de Gestão de Clientes. Em cada uma, são apresentados as categorias e os respectivos temas de pesquisa, bem como as tabelas com contagens dos indicadores (citações nas mensagens) de cada entrevistado para cada tema.

Além da quantidade total de citações, é possível observar a totalidade de entrevistados únicos que abordou cada proposição, o que determina a ordem das colunas na tabela. Para resguardar identidades e opiniões individuais, os nomes dos entrevistados não estão expostos e a ordem das linhas foi definida de forma aleatória.

Para facilitar a leitura dos resultados, nas análises das proposições referentes a cada tema estão destacadas entre parênteses o total de entrevistados únicos e o total de indicadores, no formato (x;y), onde " $x$ " é a quantidade de entrevistados e " $y$ " a quantidade de indicadores.

\subsection{Varejo Multicanal e Omnichannel}

Neste tópico, são analisadas as respostas sobre as seguintes categorias:

(i) Cenário competitivo do varejo brasileiro;

(ii) Mudanças no comportamento dos consumidores;

(iii) Características e integração do varejo multicanal.

O objetivo deste procedimento é contextualizar o ambiente competitivo e estágio de preparação das organizações para atuação no varejo multicanal, como pano de fundo para implementação de processos da estratégia de gestão de clientes. 


\subsubsection{Cenário Competitivo do Varejo Brasileiro}

Para análise do atual cenário competitivo do varejo brasileiro, foram considerados dois blocos temáticos e suas respectivas proposições extraídas das entrevistas: T1 - Desafios do Ambiente Externo; T2 - Desafios do Ambiente Interno.

A tabela a seguir contém a contagem de indicadores (frases ou citações) que compõem cada proposição do tema Desafios do Ambiente Externo, visando entender as similaridades e diferenças de opiniões dos entrevistados.

Tabela 3 - Desafios do Ambiente Externo

\begin{tabular}{|c|c|c|c|}
\hline $\begin{array}{c}\text { Profissionais } \\
\text { Entrevistados }\end{array}$ & $\begin{array}{c}\text { Trise } \\
\text { Econôm. }\end{array}$ & $\begin{array}{c}\text { Tovas } \\
\text { Tecnolog. }\end{array}$ & $\begin{array}{c}\text { Concor- } \\
\text { rência }\end{array}$ \\
\cline { 2 - 4 } & 1 & - & 1 \\
\hline Entrevistado 1 & 3 & 1 & 1 \\
\hline Entrevistado 2 & - & - & 2 \\
\hline Entrevistado 3 & 1 & 1 & 2 \\
\hline Entrevistado 5 & 1 & 1 & - \\
\hline Entrevistado 6 & 2 & 1 & 1 \\
\hline Entrevistado 7 & 1 & 1 & - \\
\hline Entrevistado 8 & 1 & 2 & - \\
\hline Entrevistado 9 & - & 1 & 1 \\
\hline Entrevistado 10 & 2 & - & - \\
\hline Entrevistado 11 & - & 1 & - \\
\hline Entrevistado 12 & 1 & - & - \\
\hline Entrevistado 13 & 1 & - & - \\
\hline Total Indicadores & $\mathbf{1 4}$ & $\mathbf{9}$ & $\mathbf{8}$ \\
\hline \% Indicadores & $45,2 \%$ & $29,0 \%$ & $25,8 \%$ \\
\hline Total Entrevistados & $\mathbf{1 0}$ & $\mathbf{8}$ & $\mathbf{6}$ \\
\hline
\end{tabular}

Fonte: Elaborado pelo autor.

A crise econômica brasileira $(10 ; 14)$ foi citada pela maioria dos entrevistados como o principal desafio do atual cenário do varejo, seguido de perto pela preocupação com o surgimento de novas tecnologias $(8 ; 9)$. O aumento da concorrência $(6 ; 8)$ foi um fator citado por menos metade dos entrevistados. 
A atual crise econômica, com elevadas taxas de inflação, altas taxas de juros e PIB em queda nos últimos dois anos (2014-2015), afeta o emprego, a renda dos consumidores e disponibilidade de crédito. Em decorrência desse cenário, ela foi citada pela maioria dos entrevistados como o maior desafio atual dos varejistas. Esta conjuntura afeta a confiança dos consumidores, que estão mais seletivos em relação às suas compras e querem gastar menos e melhor.

Nos anos anteriores à crise, diante do grande crescimento econômico do país, com aumento da renda, oferta de crédito e ascensão da classe $C$, as organizações varejistas investiram muito em estratégias e ferramentas para captar receitas. Com a crise, os resultados foram afetados, o retorno esperado não veio e boa parte dos varejistas tiveram que tomar medidas drásticas para ajustar sua estrutura ao momento, como revisar orçamentos, reduzir custos e investimentos, fechar operações deficitárias e evitar desperdícios, focando no que é básico para a operação de varejo ("back to basics").

Nestes momentos, despesas e investimentos de marketing, serviços e atendimento a clientes são os primeiros a serem reduzidos, devido à crença de que impactam pouco os resultados e a geração de valor no curto prazo. Diante desse cenário, desafio maior é gerar demanda e caixa, por isso o foco é trabalhar promoções e vendas.

Embora seja considerado um dos piores momentos do varejo brasileiro, alguns entrevistados acreditam que esta conjuntura macroeconômica é cíclica e que, em breve, o crescimento será retomado. O lado positivo é que os varejistas passaram por um processo de maturidade e acredita-se que estarão mais fortalecidos quando o mercado voltar a aquecer, com melhor gestão de custos, otimização de recursos e revisão de processos para ganhar eficiência operacional.

Por outro lado, alguns varejistas vivem uma inércia estratégica em momentos de crise, atuando de forma muito reativa e sem conseguir lidar com o ambiente multicanal. Alguns não resistiram e estão passando por processo de falência ou recuperação judicial.

A segunda proposição mais citada do ambiente externo é o surgimento de novas tecnologias (8;9). A opinião dos entrevistados é que o varejista precisa inovar sempre, embora sem descuidar do básico do negócio. A tecnologia digital e da informação evoluíram muito, mas pouco mudou na tradicional loja física, onde a maior parte das transações ainda acontecem. Há 
oportunidade para criação de novos canais, principalmente digitais, o que pode ser também uma ameaça, se pensarmos que as barreiras de entrada de novos concorrentes se tornam menores.

Existe espaço para uma revolução tecnológica nas lojas físicas, tantos nos bastidores quanto na linha de frente com o consumidor. As principais oportunidades apontadas são referentes à gestão de informações e conhecimento do negócio, criação de novos canais para distribuição de produtos, automação e melhoria da eficiência operacional, aumento de produtividade em vendas, serviços, relacionamento, experiência de consumo e gestão de categorias e estoques.

Uma questão cultural é o varejista saber o que fazer com tanta informação gerada. Nunca se teve tantos dados disponíveis, seja em transações ou no relacionamento com o consumidor. No e-commerce, a personalização da interação por meio de algoritmos é uma realidade que pode chegar às lojas físicas em algum momento.

Além da complexidade de implementação, o principal entrave apontado pelos entrevistados é o alto investimento necessário, em um setor que as margens, em geral, são muito reduzidas. Ao longo do tempo, a maior adesão de varejistas e ganhos de escala podem contribuir para adoção de novas tecnologias.

Neste contexto econômico e de novas tecnologias, observa-se aumento da concorrência $(6 ; 8)$ em busca por participação nos gastos dos consumidores (share of wallet), em uma verdadeira guerra de preços e promoções, sacrificando a margem e limitando a percepção de valor do varejo pelo mercado consumidor.

O próprio ambiente multicanal contribui para esta concorrência, com diferentes canais off-line e on-line competindo pela atenção do consumidor e conversão das vendas. Dois entrevistados apontaram, ainda, o pouco profissionalismo e concorrência desleal de setores de varejo que atuam de forma informal, com pouco ou nenhum controle tributário, e sites de e-commerce de nível duvidoso, com ofertas muito agressivas e sem respaldo aos direitos dos consumidores.

Em relação ao tema Desafios do Ambiente Interno, podemos observar, na tabela a seguir, a contagem de indicadores (frases ou citações) que compõem cada proposição. 
Tabela 4 - Desafios do Ambiente Interno

\begin{tabular}{|c|c|c|c|c|c|}
\hline \multirow{2}{*}{$\begin{array}{c}\text { Profissionais } \\
\text { Entrevistados }\end{array}$} & $\begin{array}{c}\text { T2.P1 } \\
\text { Estratégia }\end{array}$ & T2.P2 & T2.P3 & T2.P4 & T2.P5 \\
\cline { 2 - 6 } Recursos & $\begin{array}{c}\text { Atendim. } \\
\text { Serviços }\end{array}$ & $\begin{array}{c}\text { Intelig. } \\
\text { Mercado }\end{array}$ & $\begin{array}{c}\text { Produtos } \\
\text { Logística }\end{array}$ \\
\hline Entrevistado 1 & 1 & 1 & 1 & - & - \\
\hline Entrevistado 2 & 3 & 3 & - & 3 & 3 \\
\hline Entrevistado 3 & 1 & 2 & 2 & - & - \\
\hline Entrevistado 4 & - & 3 & 4 & - & - \\
\hline Entrevistado 5 & - & - & - & 1 & - \\
\hline Entrevistado 6 & 1 & 3 & - & - & 1 \\
\hline Entrevistado 7 & 1 & 3 & 2 & - & - \\
\hline Entrevistado 8 & - & - & 1 & - & - \\
\hline Entrevistado 9 & 1 & - & 5 & 1 & 2 \\
\hline Entrevistado 10 & 3 & - & 2 & - & - \\
\hline Entrevistado 11 & 2 & - & - & 1 & - \\
\hline Entrevistado 12 & - & 3 & - & - & - \\
\hline Entrevistado 13 & 5 & - & - & 5 & - \\
\hline Total Indicadores & $\mathbf{1 8}$ & $\mathbf{1 8}$ & $\mathbf{1 7}$ & $\mathbf{1 1}$ & $\mathbf{6}$ \\
\hline \% Indicadores & $25,7 \%$ & $25,7 \%$ & $24,3 \%$ & $15,7 \%$ & $8,6 \%$ \\
\hline Total Entrevistados & $\mathbf{9}$ & $\mathbf{7}$ & $\mathbf{7}$ & $\mathbf{5}$ & $\mathbf{3}$ \\
\hline & Fonte: Elaborado pelo autor. & & \\
\hline
\end{tabular}

Gestão estratégica e governança $(9 ; 18)$ foi citado pela maioria como o principal desafio interno das organizações de varejo, seguida por gestão de finanças e recursos $(7 ; 18)$, e atendimento e serviços ao consumidor $(7 ; 17)$. Monitoramento e inteligência de mercado $(5 ; 11)$ e gestão de produtos, estoques e logística $(3 ; 6)$ também foram lembrados por alguns entrevistados.

Sem posicionamento estratégico claro, alguns varejistas tendem a ir para a "guerra de preços" em momento de dificuldades ou demanda reduzida, além de enxugar a operação, o que nivela todos diante do consumidor, que não enxerga diferenças de proposta de valor e acaba optando simplesmente pelo melhor preço ou aparente custo benefício. Os concorrentes acabam todos nivelados por preços e promoções, com as marcas bastante sacrificadas e a desconfiança dos consumidores em relação à veracidade das ofertas, já que os produtos estão em "promoção" sempre. 
Como colocado por um dos especialistas, o grande desafio é, sim, fazer bem feito o que é mais básico para o negócio, mas, em paralelo, estimular a evolução, com posicionamento e proposta de valor bem definido aos consumidores, sem "machucar" tanto as margens em uma guerra de preços desenfreada que impeça o progresso da organização.

A questão chave é como balancear estratégias, iniciativas e resultados de curto, médio e longo prazos. A opinião da maior parte dos entrevistados é que as organizações estão reagindo de forma desorganizada à recessão, sem adotar uma estratégia clara.

O cenário econômico ruim também evidencia as ineficiências dos varejistas que não fizeram a devida "lição de casa" no momento de euforia econômica. Assim, ignorou-se a estrutura necessária e básica para atender os consumidores do e-commerce, começando pelo cadastro correto das informações e fotos dos produtos, conforme citado por um dos entrevistados. $\mathrm{O}$ foco no consumidor e sua experiência de consumo poderia evitar este tipo de erro.

Uma metáfora interessante colocada por um dos entrevistados, para explicar este cenário, é "não confundir terremoto com labirintite", ou seja, não confundir o que é conjuntural com o que deve ser resolvido dentro da organização. Nesse sentido, o problema maior pode estar dentro de casa.

Um dos pontos colocados por um dos executivos do varejo de moda é que a tecnologia tem evoluído e desafiado o varejo tradicional, especialmente em relação à gestão da informação e canais digitais, mas as organizações têm mudado pouco por não saberem priorizar as iniciativas ou por não estarem preparadas. Os modelos de negócios estão mudando em vários setores da economia e no varejo não é diferente. A concorrência está maior e os consumidores estão mais conectados e compram em todos os lugares.

Os varejistas tradicionais terão que sair da zona de conforto e se reinventar. A percepção é que muitos estão vendo os movimentos da concorrência e dos novos competidores e não estão se mexendo. O multicanal pode ser uma estratégia de expansão, defesa e performance.

Para um dos especialistas consultados, uma das grandes deficiências do varejo brasileiro é a baixa capacidade de implementação de projetos estratégicos. Embora muitos saibam o valor da estratégia e iniciativas para os negócios, a falta de capacitação e governança impedem que os 
planos sejam implementados. Para ele, profissionais de varejo são muito bons na execução de ações no curto prazo, de forma prática e imediatista, mas tem pouca qualificação analítica e visão estratégica de longo prazo. Esta visão de curto prazo impede que novos modelos sejam testados e gerem aprendizados para o negócio. Outro fator de entrave citado, foi a questão da governança para acompanhamento dos indicadores chave de performance (KPIs) e das iniciativas estratégicas. Os resultados são, muitas vezes, balizados somente por vendas em volume e faturamento, desprezando outros indicadores importantes, como satisfação e fidelidade do consumidor.

Em relação à gestão das finanças e recursos $(7 ; 18)$ da organização, a crença dos entrevistados é que os varejistas, em sua maioria, não fazem boa gestão dos custos e margens dos produtos vendidos. Estes indicadores chamam mais atenção nos momentos de crise econômica, quando as organizações precisam rever seus portfólios de produtos para focar nos mais rentáveis e reduzir estoques desnecessários.

Os varejistas que atuam no e-commerce, em particular, tem sofrido com a rentabilidade deste canal. Quase todas as grandes operações têm apresentado prejuízos, muitas há vários anos, o que, obviamente, não é sustentável. O consumidor se acostumou a pesquisar os preços pela internet e comprar onde for mais barato, o que condicionou o varejo on-line a oferecer sempre preços muito baixos para não perder vendas e crescer seu faturamento, mesmo que isso gere prejuízo.

Por isso, muitas organizações estão revendo suas políticas de descontos e cobrança de frete, que representa grande parte dos seus custos; além disso, elas estão focando em eficiência operacional e redução de desperdícios para se tornarem rentáveis e atenderem às expectativas dos acionistas.

As funções de atendimento e serviços ao consumidor $(7 ; 17)$ também foram lembradas por quase metade dos entrevistados como um dos grandes desafios internos dos varejistas. Convivendo com diferentes gerações e perfis de consumidores, as organizações precisam adaptar os seus negócios às necessidades e exigências dos consumidores, de forma sustentável e lucrativa. 
Uma vez que os consumidores estão mais conectados e bem informados, os vendedores têm de ser treinados para orientá-los em suas compras e esclarecer suas diversas dúvidas. Como o consumidor está muito acostumado a preços e promoções, conforme já foi abordado, a entrega de serviços diferenciados, em ambiente de muita concorrência, pode ser decisiva na conquista e fidelidade dos consumidores. Isso vale principalmente para o varejo físico, onde o atendimento e serviços são mais importantes e percebidos, pois compõem a experiência do consumidor.

Segundo um dos entrevistados, as grandes redes varejistas, principalmente de autosserviço, transformaram o varejo através de uma grande oferta de produtos para abastecimento, porém perderam o contato próximo e individualizado com o consumidor, como faziam as pequenas mercearias e comércios do passado. Hoje é tudo massificado e a qualidade do atendimento e experiência, muitas vezes, está na mão das pessoas. O varejo não tem cultura de treinamento e processos que garantam a entrega de serviços diferenciados, bem como não há um incentivo ao aprendizado.

Vale lembrar que as operações se tornaram mais complexas e se fala muito em inovação, mas nem sempre consumidores encontram o básico para satisfazer suas necessidades, como pouca fila (agilidade) e baixa ruptura (disponibilidade de produtos).

Monitoramento e inteligência de mercado $(5 ; 11)$ foi outro desafio citado por quase metade dos entrevistados. Os varejistas precisam usar o grande volume de informações disponíveis dentro e fora das organizações para competirem melhor e de forma mais ordenada.

As organizações precisam entender o cenário competitivo, os diferentes posicionamentos da concorrência e o comportamento dos consumidores, diante de tantas opções de compra. No Brasil, em particular, a dimensão territorial e as diferentes realidades sócio demográficas e econômicas demandam um esforço ainda maior para acompanhar a concorrência e estudar as necessidades e perfis distintos dos consumidores.

Dados transacionais e de interações nos diversos canais também podem ser úteis para trazer mais inteligência e pertinência ao relacionamento com os consumidores. Como possibilidade, existe a recomendação de produtos, soluções e canais mais adequados ao perfil do consumidor, além da personalização de serviços e do próprio relacionamento. 
$\mathrm{Na}$ gestão do relacionamento com clientes, tão importante quanto a capacidade de conhecer os consumidores é a capacidade de implementar iniciativas a partir deste conhecimento. Extrair os dados dos diversos pontos de contato não é um problema para o varejo, mas utilizá-los em processos analíticos e de geração de insights acionáveis é algo novo no Brasil. O processo de entender comportamentos e movimentos de consumidores, propor modelos e ações, mensurar resultados e gerar aprendizados pode ser uma forma de obter vantagens sobre a concorrência.

Ainda dentro dos desafios internos, a gestão de produtos, estoques e logística (3;6) é apontada por alguns entrevistados como função essencial no varejo, mas que não está sendo cuidada como deveria. Ao mesmo tempo que precisam de inovação para atender às necessidades e desejos dos consumidores nos diferentes canais, conforme a conveniência destes, as organizações de varejo precisam cuidar do básico do negócio, como o gerenciamento de categorias e gestão de estoques, evitando a ruptura dos produtos mais essenciais e de maior impacto aos negócios, bem como excedente de produtos menos consumidos. Precisam também estar atentos a como processos e tecnologias nestas áreas podem ajudar a melhorar a eficiência e a rentabilidade.

\subsubsection{Mudanças no Comportamento dos Consumidores}

Para análise das mudanças no comportamento dos consumidores, foram considerados dois blocos temáticos e suas respectivas proposições extraídas das entrevistas: T3 - Mudanças Motivadas pela Tecnologia; T4 - Necessidades e Atitudes em Relação ao Consumo.

A tabela a seguir inclui a contagem de indicadores (frases ou citações) que compõem cada proposição do tema Mudanças Motivadas pela Evolução Tecnológica, com o objetivo de entender as similaridades e as diferenças de opiniões dos entrevistados. 


\section{Tabela 5 - Mudanças Motivadas pela Evolução Tecnológica}

\begin{tabular}{|c|c|c|}
\hline Profissionais & T3.P1 & T3.P2 \\
\cline { 2 - 3 } Entrevistados & $\begin{array}{c}\text { Conecti- } \\
\text { vidade }\end{array}$ & $\begin{array}{c}\text { Acesso } \\
\text { Informaç. }\end{array}$ \\
\hline Entrevistado 1 & 1 & - \\
\hline Entrevistado 2 & 1 & 1 \\
\hline Entrevistado 3 & 2 & 6 \\
\hline Entrevistado 4 & 1 & 3 \\
\hline Entrevistado 5 & 2 & - \\
\hline Entrevistado 6 & 2 & 2 \\
\hline Entrevistado 7 & 2 & 2 \\
\hline Entrevistado 8 & 1 & 2 \\
\hline Entrevistado 9 & 4 & 3 \\
\hline Entrevistado 10 & 1 & 2 \\
\hline Entrevistado 11 & 3 & 1 \\
\hline Entrevistado 12 & 1 & - \\
\hline Entrevistado 13 & 1 & - \\
\hline Total Indicadores & $\mathbf{2 2}$ & $\mathbf{2 2}$ \\
\hline \% Indicadores & $50,0 \%$ & $50 \%$ \\
\hline Total Entrevistados & $\mathbf{1 3}$ & $\mathbf{9}$ \\
\hline
\end{tabular}

Fonte: Elaborado pelo autor.

Maior conectividade e mobilidade (13;22) foi um fator observado por todos os entrevistados como o principal desencadeador da mudança comportamental motivada pela evolução tecnológica. Foram muitos os indicadores identificados. O maior acesso a informações $(9 ; 22)$ também foi lembrado pela maioria.

Com a disponibilidade de internet rápida via celular nos principais centros urbanos, as pessoas estão conectadas o tempo todo e podem ter acesso à conteúdo, serviços, redes sociais e canais digitais a qualquer momento, por meio de páginas na internet ou aplicativos com funções específicas. Os consumidores, especialmente os mais jovens, estão habituados a ficar com o celular sempre à mão, inclusive quando estão fazendo outras atividades, como assistir TV.

Por meio de dispositivos móveis, como smartphones e tablets, podem levar as informações consigo ou acessá-las no local que desejarem, inclusive nos locais de compra de produtos. A conectividade e mobilidade permitem ao consumidor pesquisar preços e checar informações e 
referências de produtos, por exemplo, no momento da decisão de compra. Como colocado por um dos entrevistados, "hoje, só compra errado quem quer". Assim, com o celular em mãos, as pessoas estão sempre em contato com novos conteúdos e em processo de compra de produtos.

Este maior acesso a informações $(9 ; 22)$ permite que o consumidor seja mais consciente e crítico em relação às suas decisões de aquisição, possibilitando, inclusive, que este fique mais disposto a experimentar novos produtos e serviços. Quase todos entrevistados reforçaram a ideia de maior "poder" do consumidor nas suas transações e no relacionamento com o varejo, e que se intensificou nos últimos anos com o advento de dispositivos móveis para obtenção de informações e realização de compras.

Sobre o tema Necessidades e Atitudes em Relação ao Consumo, podemos observar, na tabela a seguir, a contagem de indicadores (frases ou citações) que compõem cada proposição.

Tabela 6 - Necessidades e Atitudes em Relação ao Consumo

\begin{tabular}{|c|c|c|c|c|c|}
\hline $\begin{array}{c}\text { Profissionais } \\
\text { Entrevistados }\end{array}$ & $\begin{array}{c}\text { T4.P1 } \\
\text { enveni- } \\
\text { encia }\end{array}$ & $\begin{array}{c}\text { Experi- } \\
\text { encia }\end{array}$ & $\begin{array}{c}\text { Sócio } \\
\text { Demog. }\end{array}$ & $\begin{array}{c}\text { Jornada } \\
\text { Compra }\end{array}$ & $\begin{array}{c}\text { Respons. } \\
\text { Social }\end{array}$ \\
\hline Entrevistado 1 & 1 & - & 1 & - & - \\
\hline Entrevistado 2 & 4 & 1 & 6 & 1 & 1 \\
\hline Entrevistado 3 & - & 1 & 1 & 2 & - \\
\hline Entrevistado 4 & 1 & - & - & - & - \\
\hline Entrevistado 5 & 1 & 3 & 3 & - & - \\
\hline Entrevistado 6 & - & 2 & 3 & 1 & 1 \\
\hline Entrevistado 7 & - & 1 & 3 & - & - \\
\hline Entrevistado 8 & 5 & 4 & 2 & 1 & - \\
\hline Entrevistado 9 & 3 & 3 & - & - & - \\
\hline Entrevistado 10 & 2 & 3 & 1 & 2 & - \\
\hline Entrevistado 11 & 4 & 2 & - & - & - \\
\hline Entrevistado 12 & 2 & - & - & - & - \\
\hline Entrevistado 13 & 2 & - & - & - & - \\
\hline Total Indicadores & $\mathbf{2 5}$ & $\mathbf{2 0}$ & $\mathbf{2 0}$ & $\mathbf{7}$ & $\mathbf{2}$ \\
\hline \% Indicadores & $33,8 \%$ & $27,0 \%$ & $27,0 \%$ & $9,5 \%$ & $2,7 \%$ \\
\hline Total Entrevistados & $\mathbf{1 0}$ & $\mathbf{9}$ & $\mathbf{8}$ & $\mathbf{5}$ & $\mathbf{2}$ \\
\hline
\end{tabular}

Fonte: Elaborado pelo autor. 
Em relação ao tema de necessidades e atitudes, a busca por praticidade e conveniência $(10 ; 25)$ foi abordada pela maioria dos entrevistados, com muitas citações, seguida pela busca por melhor experiência de consumo $(9 ; 20)$ e por fatores sócio demográficos $(8 ; 20)$. A questão da orientação pela jornada de compra $(5 ; 7)$ e a responsabilidade socioambiental $(2 ; 2)$ também foram proposições lembradas, com bem menos citações.

A busca por praticidade e conveniência também ajuda a entender o desejo do consumidor por uma melhor experiência de compra. É notória a dificuldade de deslocamento nas grandes cidades, o que leva o consumidor a buscar canais mais práticos e rápidos para suas compras, seja pela proximidade de sua residência ou trabalho, ou pela rapidez na compra ou atendimento. O processo de pagamento ágil e a entrega ou retirada no local de preferência, também são fatores que influenciam na escolha do cliente.

O setor varejista enfrentou um processo de transformação muito grande nos últimos 20 anos, passando de poucos canais indiferenciados e massificados, para inúmeros mais sofisticados e com grande possibilidade de personalização, como é o caso do e-commerce, e evoluindo para compras através de dispositivos móveis, redes sociais, marketplaces, vitrines virtuais, etc. Compras em grande volume foram substituídas, em parte, pelas compras menores de reposição, mais práticas e rápidas, ou pelas de conveniência, quando necessário. $\mathrm{O}$ varejo de proximidade, com lojas localizadas dentro dos bairros, é um dos segmentos que mais cresce dentro do varejo, pela praticidade e qualidade do atendimento e pela possibilidade de desenvolvimento de uma relação mais próxima com o consumidor.

Parte destas mudanças é reflexo das exigências dos consumidores, que têm cada vez menos tempo e procuram otimizar suas compras, com maior praticidade e conveniência, trazendo um novo conceito para o varejo, mesmo o físico. Um exemplo citado por um dos entrevistados é a mudança das grandes redes de farmácia para o modelo das drugstores americanas, que têm boa capilaridade junto ao seu público e vendem muito mais do que medicamentos, sendo este um formato muito mais conveniente ao consumidor.

A conclusão de alguns entrevistados é que o consumidor sempre foi multicanal, mas não tinha como exercer este desejo, devido às opções escassas e restrições físicas dos canais tradicionais. Nesse sentido, constatou-se que o cliente quer ter acesso aos produtos independentemente de 
onde o fornecedor está e os canais que o varejo oferece. Como colocado por um dos entrevistados, "o consumidor enxerga marcas e produtos, quem enxerga canais é o varejo".

Essa busca é ainda mais comum entre o público mais jovem, mais acostumado à experiência de consumo por meios digitais, como aplicativos de celular e redes sociais, e menos avesso a atritos de atendimento e filas. Para atendê-los, é necessário investir em novos canais on-line e no desenho de processos simples e ágeis, como, por exemplo, processos de cadastramento e pagamento que devem ter um tempo de resposta muito rápido. A facilidade de acesso obriga as organizações de varejo a se mexerem, com o risco de perderem clientes e receitas. Quanto mais automatização e menos intermediários, melhor, mais fácil, rápido e menos atribulado o processo de compra. Um dos especialistas citou os bancos como modelo, uma vez que eles são cada vez mais digitais e estão fechando algumas de suas agências.

Neste contexto, a oferta de serviços de qualidade, uma boa experiência de compra e conveniência têm peso muito grande na decisão de escolha do canal e das marcas, embora exista uma boa parte do mercado consumidor que ainda é orientado por preços e promoções, por limitações financeiras ou até mesmo pelo fato de ter sido doutrinado pelo varejo tradicional a pensar desta forma.

A procura por preços mais baixos aumenta em momentos de crise econômica e queda de renda, mesmo com prejuízo à conveniência e experiência, o que explica o sucesso atual dos "atacarejos". Neste cenário, os varejistas posicionados como conveniência e serviços sofrem mais, conforme relato de um dos entrevistados.

O maior acesso às informações e opções de canais de compra também levam o consumidor à busca por melhor experiência de consumo $(9 ; 20)$. A expectativa pela qualidade dos produtos e serviços é alta, principalmente quando eles são confrontados com os novos modelos de negócios que utilizam a internet e aplicativos móveis para colocar em contato direto os consumidores e seus fornecedores, com menos intermediários, com maior fluidez e menor atrito possível.

Foram citados como novos modelos de negócios os aplicativos Uber (transporte) e Airbnb (hospedagem), dentre outros exemplos serviços que permitem uma experiência personalizada 
e quase sem surpresas desagradáveis. Estas organizações já nasceram no mundo digital e não trazem os legados e vícios de serviços e atendimento do varejo físico tradicional.

Outro elemento trazido pelos entrevistados, foi o crescimento da classe média, uma vez que este forçou as organizações de varejo a oferecerem uma melhor experiência de compra. Isso se deve, sobretudo, à maior exigência do público-alvo e à necessidade de querer ver e tocar o produto na loja, mesmo tendo pesquisado informações antes pela internet. Com a crise econômica, a diminuição da renda e o descontrole de crédito, é ainda maior a consciência dessas camadas quanto ao valor do consumo.

O ponto de venda passa a ser local de experiência de marca e relacionamento com consumidor, deixando de constituir-se apenas enquanto lugar de aquisição de produtos e serviços. Com o maior volume e variedade de opções de produtos e canais de compra, os atributos mais intangíveis, ligados ao bem-estar e prazer pessoal no momento da compra, passaram a ser mais valorizados.

Alguns fatores sociodemográficos $(8 ; 20)$ também foram citados pelos entrevistados para explicar as mudanças no comportamento dos consumidores nos últimos anos.

Um dos entrevistados enfatizou o que, na opinião dele, são os três motores que transformam os mercados: mudanças demográficas, mudanças tecnológicas e ciclos econômicos. Algumas tendências que afetam o varejo foram observadas pelos entrevistados de forma pontual:

- Envelhecimento da população, com maior expectativa de vida;

- Busca por uma vida mais saudável em todas as faixas etárias;

- Maior participação da mulher no mercado de trabalho;

- Novos arranjos familiares de todos os tipos e tamanhos;

- Qualificação do consumo, ou seja, busca por melhor experiência de compra;

- Sustentabilidade, no sentido de procurar canais e produtos que demonstrem maior responsabilidade socioambiental.

Uma tendência observada de forma quase unânime pelos profissionais é a entrada no mercado consumidor da chamada "Geração Y" ou "Geração Milênio", nascidos nos centros urbanos a 
partir de meados dos anos 80 e 90 e que usufruíram de crescimento econômico, educacional e tecnológico sem precedentes, incluindo o advento da internet. Eles são muito adaptados aos meios digitais, estão sempre conectados e preferem interfaces de compra simples e amigáveis. A percepção é de que a maioria dos varejistas tradicionais ainda não está preparada para lidar com este perfil de consumidor, que vem ganhando importância no mercado e será responsável pela maior parte das compras em um futuro próximo.

Pelo seu comportamento social e de consumo, essa geração demanda um tratamento diferente, ao mesmo tempo em que as organizações precisam atender aos anseios de consumidores de gerações anteriores, que ainda formam a base de faturamento dos principais varejistas e que mantêm hábitos distintos de acesso a meios de comunicação, compra de produtos e serviços, e uso de meios de pagamento, por exemplo.

Em relação à orientação pela jornada de compra $(5 ; 7)$, observa-se que o consumidor multicanal se guia por uma missão de compra definida, como a aquisição de um sortimento específico, abastecimento ou reposição de produtos. Assim, ele busca o canal mais conveniente, prático e, muitas vezes, econômico, para satisfazer as necessidades de consumo. Nesta jornada, o consumidor procurar uma boa experiência de compra e uma boa relação custo x benefício. $\mathrm{O}$ varejista deve, então, procurar atender de forma satisfatória os diferentes perfis de consumidores em suas diferentes ocasiões de consumo, conforme suas necessidades e preferências de compra; incluindo nesse contexto a disponibilidade de canais mais práticos e convenientes.

Com a internet, um comportamento recorrente entre os consumidores é a pesquisa durante a jornada de compra, com comparação de preços e coleta de informações sobre o produto, seguida pela visita à loja física para avaliação do produto in loco, em um processo conhecido por showrooming. A mobilidade por meio de dispositivos eletrônicos é um aliado nesta missão. $\mathrm{O}$ telefone celular pode ser utilizado para checar informações na loja ou mesmo para fechar a compra.

Sendo assim, a internet é usada como vitrine e canal para fechamento da compra; já a loja física é tida como local para avaliação, experimentação e esclarecimento de dúvidas específicas. A questão é como o varejista pode atuar para converter a venda neste processo, seja loja física ou canal digital, ou assumir o papel de estoque do e-commerce para retirada na loja (pick-up store). 
Por fim, a responsabilidade socioambiental $(2 ; 2)$ também foi citada por dois profissionais como um dos fatores que influenciam a decisão de compra dos consumidores, tanto na escolha da marca do produto quanto do canal de venda. O propósito da organização e suas atitudes são atributos valorizados pelo mercado como um todo, estes se tornam ainda mais importantes quando nos referimos à geração milênio.

\subsubsection{Características e Integração do Varejo Multicanal}

Para análise das características e da integração do varejo multicanal, foram avaliados quatro blocos temáticos e suas respectivas proposições citadas nas entrevistas: T5 - Principais Canais e Tendências, T6 - Integração e Conflito de Canais, T7 - Preparação e Principais Dificuldades das Organizações, T8 - Casos e Melhores Práticas.

A tabela a seguir encerra a contagem de indicadores (frases ou citações) que compõem cada proposição do tema Principais Canais e Tendências, com objetivo de entender similaridades e diferenças de opiniões dos entrevistados. 
Tabela 7 - Principais Canais e Tendências

\begin{tabular}{|c|c|c|c|c|c|}
\hline $\begin{array}{c}\text { Profissionais } \\
\text { Entrevistados }\end{array}$ & T5.P1 & T5.P2 & T5.P3 & T5.P4 & T5.P5 \\
\cline { 2 - 6 } Digitais & $\begin{array}{c}\text { Canais } \\
\text { Tradic. }\end{array}$ & $\begin{array}{c}\text { Disposit. } \\
\text { Móveis }\end{array}$ & $\begin{array}{c}\text { Novos } \\
\text { Canais }\end{array}$ & $\begin{array}{c}\text { Redes } \\
\text { Sociais }\end{array}$ \\
\hline Entrevistado 1 & 4 & 1 & 2 & 1 & - \\
\hline Entrevistado 2 & 1 & 1 & 1 & - & 1 \\
\hline Entrevistado 3 & 3 & 4 & 4 & 2 & - \\
\hline Entrevistado 4 & 3 & 3 & 1 & 2 & - \\
\hline Entrevistado 5 & 4 & 4 & 2 & - & 2 \\
\hline Entrevistado 6 & 4 & 3 & 2 & 3 & 1 \\
\hline Entrevistado 7 & 2 & - & 1 & 2 & 1 \\
\hline Entrevistado 8 & 4 & 2 & 2 & 2 & - \\
\hline Entrevistado 9 & 3 & 3 & - & 2 & - \\
\hline Entrevistado 10 & 3 & 1 & - & - & - \\
\hline Entrevistado 11 & 1 & 1 & 1 & 1 & - \\
\hline Entrevistado 12 & 5 & 3 & 2 & 2 & - \\
\hline Entrevistado 13 & 3 & - & 3 & - & 1 \\
\hline Total Indicadores & $\mathbf{4 0}$ & $\mathbf{2 6}$ & $\mathbf{2 1}$ & $\mathbf{1 7}$ & $\mathbf{6}$ \\
\hline \% Indicadores & $36,4 \%$ & $23,6 \%$ & $19,1 \%$ & $15,5 \%$ & $5,5 \%$ \\
\hline Total Entrevistados & $\mathbf{1 3}$ & $\mathbf{1 1}$ & $\mathbf{1 1}$ & $\mathbf{9}$ & $\mathbf{5}$ \\
\hline
\end{tabular}

Fonte: Elaborado pelo autor.

Em relação aos principais canais e tendências para varejo multicanal, o e-commerce / canais digitais $(13 ; 40)$ foram citados pela totalidade dos entrevistados e com alta frequência. Os canais tradicionais $(11 ; 26)$ e os dispositivos móveis $(11 ; 21)$ também foram muito citados por quase todos. A maioria falou também sobre tendências e novos canais $(9 ; 17)$, porém as redes sociais $(5 ; 6)$ foram pouco lembradas em comparação aos demais.

Com cerca de 20 anos de existência no Brasil, desde os primórdios da internet comercial, o $e$ commerce é um canal que já atingiu maturidade nas principais categorias de produtos, como livros, eletroeletrônicos, cosméticos, utilidades, brinquedos e remédios; mas ainda continua emergente em outras, como moda e automóveis. A penetração do e-commerce no varejo brasileiro ainda tem muito a crescer, a exemplo do que ocorreu nos países desenvolvidos; no entanto, com menos intensidade do que nos últimos anos. Com a população mais conectada e munida de dispositivos móveis, a tendência é que o comércio online ocupe cada vez mais espaço nos hábitos de compra, em qualquer região e classe social. A questão é como crescer de forma 
sustentável, já que a maioria das operações de e-commerce de médio ou grande porte ainda são deficitárias.

Alguns entrevistados acreditam que a próxima grande onda do e-commerce será o segmento alimentício (supermercados), ainda incipiente, mas que deve ganhar força com iniciativas de delivery nas proximidades ou retirada direto na loja. Esta opção, chamada de pick-up store, foi citada por vários dos entrevistados como uma tendência. Outra possibilidade que vem sendo testada dentro e fora do Brasil é o modelo de loja ou ponto (drive-thru) exclusivo para retirada de produtos; essa alternativa encontra vantagens reais em custos de logística (frete) e agilidade na entrega.

É interessante observar que os entrevistados fizeram colocações mais relacionadas a canais de vendas (que é o foco maior do varejo), embora o multicanal englobe também canais de pósvendas e comunicação. Para atendimento e relacionamento, foram lembrados os websites com conteúdo, informações e serviços de autoatendimento, o atendente virtual (on-line) em tempo real (chat) e o envio de e-mails informativos ou de marketing. Um dos pesquisados comentou que a verba destinada para marketing digital é bem maior para vendas no e-commerce do que para relacionamento ou gestão da marca, graças à capacidade e velocidade que o primeiro tem de "fazer acontecer".

Em relação aos canais tradicionais (off-line) $(11 ; 26)$, representados principalmente por lojas físicas, a opinião unânime é de que continuam e continuarão sendo fundamentais no varejo, mesmo com o crescimento do e-commerce, embora os especialistas mais orientados a canais digitais entendam que, no futuro, o papel das lojas físicas será de apoiar as vendas nos canais digitais.

Como colocou um entrevistado, o "varejo físico não morreu e não vai morrer". Mas, como observou outro, precisa se reinventar para se adaptar aos "novos tempos" e aprender com o mundo digital, o que significa ser mais rápido nas campanhas e promoções, e apresentar ofertas personalizadas. Alguns acreditam que a próxima revolução digital será no varejo físico, como já aconteceu com os bancos e vem acontecendo com o setor de serviços.

Segundo os entrevistados, a loja física tem como principais vantagens o contato direto com os produtos, a experiência do atendimento e do ambiente (sensoriais), os serviços agregados e o 
diferencial humano. Mesmos os consumidores "digitalizados" gostam de ir às lojas para ver e experimentar os produtos. Como limitação, estas possuem baixa capacidade de investimentos, altos custos da operação e capacitação e alta taxa de turn-over de colaboradores.

Foram lembradas também as vendas por telefone, os catálogos e malas diretas que persistem e têm público específico, a venda direta porta-a-porta (ainda forte), a venda automatizada (vending-machines), as lojas conceito (flagship store ou concept store) e as lojas temporárias (pop-up store), montadas em locais de grande movimento em períodos específicos.

Os dispositivos móveis (mobile) $(11 ; 21)$ foram citados por quase todos os entrevistados, como uma realidade e prioridade para os varejistas. Quem ainda não tem estratégia para este canal, está desenvolvendo ou pensando em desenvolver. O mobile permite a abundância de comunicação e opções de interação, viabilizando a apresentação de ofertas personalizadas e novas formas de aquisição de produtos, por meio de aplicativos e geolocalização, por exemplo.

Por suas características e hábitos de utilização, o mobile demanda novos formatos de comunicação e de experiência de usuário. As iniciativas das organizações de varejo vão desde a criação de sites responsivos ou específicos, até o desenvolvimento de aplicativos próprios com informações, ofertas, serviços, notificações, jogos e, claro, a possibilidade de compra.

Tudo está no celular, em mãos, de forma rápida, prática e até lúdica. Além da compra direta de produtos, a ideia é que os smartphones sejam usados para complementar a experiência de loja, como notificações de ofertas, busca por informações e realidade virtual.

Apesar do aumento da penetração dos dispositivos móveis - especialmente smartphones - na população brasileira, um dos especialistas avalia que as empresas não estão preparadas ou não estão conseguindo dar vazão à oportunidade, pois o volume de vendas pelo mobile não acompanha o crescimento do canal como deveria.

Sobre outras tendências e novos canais $(9 ; 17)$, foi muito comentado justamente a integração do mundo físico com o digital, com aproveitamento do mobile, trazendo inúmeras possibilidades de interações, campanhas e canais, das formas mais diversas, a serviço de marketing, vendas e relacionamento com consumidores. Obviamente todas têm novos custos 
associados, por isso a escolha deve ser feita de forma estratégica e de acordo com a proposta de valor da marca.

Canais digitais são protagonistas, com impacto a qualquer hora e lugar, fornecendo conteúdo e possibilidades de consumo, ou influenciando as decisões de compra, como, por exemplo, por intermédio de blogueiros (conteúdos pessoais por meio de textos) e youtubers (conteúdos pessoais por meio de vídeos).

Novos canais de vendas, pós-vendas, relacionamento e comunicação vem surgindo a partir de tecnologias digitais e de mobilidade, como aplicativos, compradores de preço e redes sociais. Outra tendência apontada é a automação dos processos de atendimento e vendas, por meio de totens interativos, vitrines, provadores e catálogos virtuais dentro de lojas físicas, que muitas vezes irão atuar como show-room e sem estoques. Como premissa, tem-se a personalização das ofertas, como já é feito nos canais digitais, por meio das informações capturadas nas interações.

Alguns entrevistados colocaram a tendência de participação da indústria de bens de consumo para viabilizar as iniciativas de novos canais junto aos varejistas, como, por exemplo, totens interativos exclusivos dos produtos da marca disponíveis dentro nas lojas. Outra possibilidade é o compartilhamento de informações sobre preferências, hábitos e comportamentos de consumidores, visando disponibilizar produtos nos canais e formatos mais aderentes, com visão multicanal, como já é feito pela indústria de cosméticos junto às redes de drogarias. A indústria também tem aberto lojas físicas e virtuais, como sites e aplicativos, para dar aos consumidores acesso direto aos produtos, além de trabalhar novos conceitos e lançamentos. Essa estratégia pode criar conflitos de preços em comparação aos varejistas, se não for bem combinada.

Por fim, as redes sociais (social media) $(5 ; 6)$ foram pouco lembradas, possivelmente pelo baixo impacto em vendas de forma direta, sendo mais usadas para ações promocionais, iniciativas de gestão da marca (branding) e relacionamento com os consumidores.

Há alguns anos, as iniciativas de vendas por redes sociais (social commerce) foram apontadas como tendência, mas não se concretizaram por resistência dos usuários em receber abordagens comerciais pelo canal, mesmo que por indicação de amigos. As organizações ainda estão buscando a melhor forma de rentabilizar o canal por meio dos seus fãs ou seguidores. Enquanto 
isso, geram negócios por meio de anúncios de promoções com direcionamento para o $e$ commerce.

Em relação ao tema Integração e Conflito de Canais, podemos observar, na tabela a seguir, a contagem de indicadores (frases ou citações) que compõem cada proposição.

Tabela 8 - Integração e Conflito de Canais

\begin{tabular}{|c|c|c|c|c|}
\hline \multirow{2}{*}{$\begin{array}{c}\text { Profissionais } \\
\text { Entrevistados }\end{array}$} & T6.P1 & T6.P2 & T6.P3 & T6.P4 \\
\hline & $\begin{array}{l}\text { Preços } \\
\text { Promo }\end{array}$ & $\begin{array}{l}\text { Informaç. } \\
\text { Produtos }\end{array}$ & $\begin{array}{l}\text { Objetivos } \\
\text { Metas }\end{array}$ & $\begin{array}{l}\text { Comunic. } \\
\text { Campanha }\end{array}$ \\
\hline Entrevistado 1 & 1 & - & 2 & 1 \\
\hline Entrevistado 2 & 1 & 1 & - & - \\
\hline Entrevistado 3 & 2 & 1 & - & 2 \\
\hline Entrevistado 4 & 2 & - & 1 & - \\
\hline Entrevistado 5 & 1 & 1 & 2 & 1 \\
\hline Entrevistado 6 & 2 & 1 & - & - \\
\hline Entrevistado 7 & 2 & 2 & 1 & - \\
\hline Entrevistado 8 & - & 1 & - & - \\
\hline Entrevistado 9 & 2 & 1 & - & - \\
\hline Entrevistado 10 & - & 1 & - & - \\
\hline Entrevistado 11 & - & - & 1 & - \\
\hline Entrevistado 12 & 1 & 1 & 2 & 1 \\
\hline Entrevistado 13 & - & - & 1 & - \\
\hline Total Indicadores & 14 & 10 & 10 & 5 \\
\hline$\%$ Indicadores & $35,9 \%$ & $25,6 \%$ & $25,6 \%$ & $12,8 \%$ \\
\hline Total Entrevistados & 9 & 9 & 7 & 4 \\
\hline
\end{tabular}

Fonte: Elaborado pelo autor.

A política de preços e promoções $(9 ; 14)$ foi citada pela maioria dos especialistas como atributo de integração ou conflito no varejo multicanal, junto com informações de produtos e ofertas $(9 ; 10)$, e seguidos pelos objetivos, metas e incentivos $(7 ; 10)$ dos canais. Comunicação e campanhas de marketing $(4 ; 5)$ também foram lembradas, porém com baixa frequência.

Colocar os mesmos preços e promoções nos diferentes canais parece algo básico para atuação no varejo multicanal, porém são atributos que apresentam menos clareza para o consumidor, 
gerando conflitos. O posicionamento de preço é importante considerando que as informações são facilmente pesquisadas pelos consumidores antes ou no momento da compra.

Os preços dos mesmos produtos nas lojas físicas ou virtuais, porém, costumam ser diferentes, com valores menores no e-commerce, devido ao maior custo das operações de loja física e à política de descontos mais agressiva das lojas virtuais. Algumas lojas físicas têm políticas de descontos para chegar próximos aos preços das digitais, dentro de limites de margens, mas nem sempre conseguem chegar aos valores questionados pelos consumidores.

As políticas também são diferentes porque, via de regra, as operações são separadas em áreas ou unidades de negócios diferentes, que não estão integradas ou têm autonomia para definir e praticar seus preços e promoções. Para o consumidor, pode parecer confuso, pois ele enxerga marcas de varejo, e não canais de varejo, e muitas vezes não tem a noção do que acontece nos bastidores. Um dos especialistas formulou a seguinte frase: "o consumidor enxerga marcas, não canais; quem enxerga canais é o varejista".

Embora seja quase consenso entre os varejistas que os preços deveriam ser integrados, um dos entrevistados deu exemplos de setores em que a precificação é dinâmica, variando de acordo com a demanda e conforme o produto, região, data, dia da semana, horário, canal de compra e até pelo perfil do cliente. São os casos de alguns bancos, seguradoras e companhias aéreas, principalmente. A precificação no varejo tem que ser única ou também pode ser dinâmica?

Em relação a informações de produtos e ofertas $(9 ; 10)$, o conflito parece ser ainda mais grave para o consumidor, por dificultar sua pesquisa de preços e referências. Informações desencontradas geram atritos, stress e perda de tempo. As informações das lojas físicas, lojas digitais e mobile deveriam ser coerentes, na medida do possível. Com as mesmas informações e poder na mão do consumidor, ele poderia escolher o canal de sua preferência, sem controle e sem atritos.

Um exemplo disso se verifica quando os diferentes canais trabalham com portfólios de produtos diferentes. A variedade de produtos disponíveis costuma ser maior em canais digitais, devido a questões logísticas. Por isso, podem trabalhar produtos de nicho e com pouca saída, conhecidos como produtos de cauda longa. As lojas físicas não têm essa capacidade, mas poderiam oferecer os produtos por meio de totens, computadores ou dispositivos móveis com aplicativos de leitura 
dos códigos dos produtos ( $Q R$ Code, por exemplo). Um dos especialistas afirma que "o varejo físico sem informação está com os dias contados; persiste, mas não tem volta, será mandatório a integração daqui por diante". Com integração de canais e consumidor omnichannel, as lojas tendem a virar um grande show-room, com transacional passando por canais físicos e digitais.

$\mathrm{O}$ acesso à internet rápida nas lojas físicas pode fazer com que os totens e catálogos virtuais percam força, pois serão usados os dispositivos móveis do próprio consumidor. Segundo um dos entrevistados, as ferramentas de busca, como Google, e de redes sociais, como Facebook, estão criando novas soluções para integração do mundo virtual com o real, no intuito de levar tráfego para as lojas e gerar performance e relevância, por meio da movimentação do mobile.

Objetivos, metas e incentivos $(7 ; 10)$ distintos por canal são outros fatores que geram conflitos que prejudicam o relacionamento com o consumidor. Quando os objetivos e metas são diferentes, e não existe incentivo à cooperação, a tendência natural é que cada um corra atrás dos seus resultados, sem se esforçar ou se importar com os demais canais. Muitas vezes os canais concorrem entre si para atrair a atenção do consumidor e conseguir aumentar o volume de vendas, isso pode ocorrer através das lojas físicas, e-commerce ou porta a porta.

Um exemplo desse fenômeno é a compra pela internet dentro da loja física de um produto que está em falta nas prateleiras (ruptura). Se não houver metas ou incentivos aos vendedores para esta venda, como por exemplo, uma comissão, a tendência é que não se motivem e não se esforcem para auxiliar o consumidor na hora a concretizar a compra na hora pelo e-commerce. Como colocado por um dos entrevistados, "a cultura da comissão do vendedor ainda é muito forte no varejo físico". Além disso, tem que haver estrutura para acesso à internet na loja. Por esses motivos, poucas são as lojas físicas que oferecem reserva ou compra pela internet.

Comunicação e campanhas de marketing (4;5) são aspectos que também têm possibilidade de integração ou conflito de canais. Em canais não integrados, pode ocorrer de os consumidores receberem informações divergentes ou em excesso. Por exemplo, e-mails disparados por áreas diferentes com os mesmos produtos, mas preços diferentes, ou vários e-mails enviados no mesmo dia para os mesmos clientes, com pouco ou nenhum controle.

A maneira que os canais físicos e digitais falam da marca também tendem a ser diferentes. Ambos precisam vender, mas o varejo físico consegue trabalhar mais os atributos da marca e 
ser mais aspiracional. Já o varejo digital é mais agressivo na comunicação, muito orientado para performance (call-to-action), deixando de lado elementos que possam gerar dispersão.

Em campanhas de marketing de relacionamento, é possível ter algum nível de controle com a determinação de políticas de envio de comunicação dirigida, como e-mails, malas diretas e mensagens de celular (SMS), por exemplo. O consumidor pode ser visto e tratado como único nestas campanhas, caso exista um repositório de dados para centralizar as informações dos clientes, independente do canal de compra ou interação. Com ferramentas analíticas, também é possível determinar segmentos (clusters) de consumidores para desenvolvimento de réguas de relacionamento por perfil ou comportamento.

$\mathrm{O}$ acesso à internet na loja usando rede sem fio $(\mathrm{Wi}-\mathrm{Fi})$, foi citado por um dos especialistas como uma forma de identificar o cliente na loja física e fazer campanhas com recomendações conforme o perfil do consumidor, seu histórico de interação e navegação. Da mesma forma, o uso de beacons (dispositivos com conexão ao aparelho celular via bluetooth) cumpre essa função.

Na tabela a seguir, vemos a contagem de indicadores (frases ou citações) das proposições do tema Preparação e Principais Dificuldades das Organizações. 
Tabela 9 - Preparação e Principais Dificuldades das Organizações

\begin{tabular}{|c|c|c|c|c|c|c|c|}
\hline \multirow{2}{*}{$\begin{array}{c}\text { Profissionais } \\
\text { Entrevistados }\end{array}$} & T7.P1 & T7.P2 & T7.P3 & T7.P4 & T7.P5 & T7.P6 & T7.P7 \\
\cline { 2 - 8 } & Objetivos & $\begin{array}{c}\text { Estrutura } \\
\text { Recursos }\end{array}$ & $\begin{array}{c}\text { Gestão } \\
\text { Tecnolog. }\end{array}$ & $\begin{array}{c}\text { Gestão } \\
\text { Processos }\end{array}$ & $\begin{array}{c}\text { Pessoas } \\
\text { Cultura }\end{array}$ & $\begin{array}{c}\text { Estoques } \\
\text { Logística }\end{array}$ & $\begin{array}{c}\text { Legislaç. } \\
\text { Tributos }\end{array}$ \\
\hline Entrevistado 1 & 1 & - & 1 & 5 & - & 2 & - \\
\hline Entrevistado 2 & 2 & 1 & - & - & - & 1 & - \\
\hline Entrevistado 3 & 1 & 3 & - & 1 & 1 & - & - \\
\hline Entrevistado 4 & 3 & 1 & 4 & 2 & 6 & - & - \\
\hline Entrevistado 5 & - & 2 & 1 & 1 & - & - & - \\
\hline Entrevistado 6 & 2 & 2 & 2 & 1 & 1 & - & - \\
\hline Entrevistado 7 & 3 & 1 & 2 & 2 & - & - & - \\
\hline Entrevistado 8 & 4 & - & 4 & 1 & 5 & - & 1 \\
\hline Entrevistado 9 & 3 & 2 & 4 & 5 & 4 & 3 & 1 \\
\hline Entrevistado 10 & 2 & 3 & - & 2 & 1 & 2 & 2 \\
\hline Entrevistado 11 & 5 & 3 & 4 & 3 & 2 & - & - \\
\hline Entrevistado 12 & 1 & 1 & 1 & - & - & - & - \\
\hline Entrevistado 13 & 3 & 3 & 4 & - & 3 & - & - \\
\hline Total Indicadores & $\mathbf{3 0}$ & $\mathbf{2 2}$ & $\mathbf{2 7}$ & $\mathbf{2 3}$ & $\mathbf{2 3}$ & $\mathbf{8}$ & $\mathbf{4}$ \\
\hline \% Indicadores & $21,9 \%$ & $16,1 \%$ & $19,7 \%$ & $16,8 \%$ & $16,8 \%$ & $5,8 \%$ & $2,9 \%$ \\
\hline Total Entrevistados & $\mathbf{1 2}$ & $\mathbf{1 1}$ & $\mathbf{1 0}$ & $\mathbf{1 0}$ & $\mathbf{8}$ & $\mathbf{4}$ & $\mathbf{3}$ \\
\hline
\end{tabular}

Fonte: Elaborado pelo autor.

Com alta frequência de citações, as diretrizes e objetivos estratégicos (12;30) foram indicados por quase todos os entrevistados como importantes na preparação para atuação no varejo multicanal. Da mesma forma, foram bastante lembradas as proposições: estrutura e recursos organizacionais (11;22), gestão de inovação e tecnologia (10;27), e gestão de processos de negócios (10;23). A proposição de gestão de pessoas e cultura organizacional $(8 ; 23)$ foi abordada pela maioria, enquanto que gestão de estoques e logística $(4 ; 8)$, e legislação e gestão tributária $(3 ; 4)$ foram lembrados por poucos entrevistados.

A opinião de todos os entrevistados é que existe uma dificuldade muito grande no Brasil para integração dos diversos canais do varejo, no sentido de criar de fato uma visão omnichannel para os consumidores, compartilhando informações, produtos, preços e serviços. Ao mesmo tempo, a organização precisa ser eficiente na gestão do sortimento de produtos e estoques, de forma enxuta, evitando excessos de produtos ou rupturas. Ao abrir novos canais, o processo de gestão torna-se mais complexo e desafiador para o varejista, embora necessário. 
É consenso dizer que o varejista deveria chegar onde o consumidor está e deseja ser atendido. O consumidor enxerga a marca e o seu posicionamento, e muitas vezes não entende (ou não deveria entender) os motivos dos atritos entre os canais. O canal é uma visão e um problema (e problema) do varejo, e não do consumidor. E o consumidor deveria ter o mínimo atrito possível ao transitar por estes canais, ou seja, a experiência dele deveria ser positiva e fluir sem entraves.

A compra de produtos pela internet com entrega e troca na loja, seja ela comum ou dedicada somente à retirada dos produtos (pick-up store), foi um exemplo de serviço multicanal citado pela maior parte dos entrevistados. Algumas variações deste serviço permitem a retirada dos produtos em armários (lockers) dentro das próprias lojas tradicionais, em estabelecimentos de parceiros (outros varejistas) ou locais de grande tráfego, como estações de metrô ou postos de combustíveis. Este tipo de serviço ajuda a reforçar o posicionamento multicanal da marca e atrair novos consumidores que buscam maior conveniência.

Os motivos citados para a falta de integração e geração de atritos com consumidores foram:

- Ausência de estratégia: alta direção não define ou deixa claro os objetivos e diretrizes estratégicas para atuação no contexto de varejo multicanal;

- Clareza de posicionamento: não está bem definido na organização varejista como ela irá se posicionar no mercado em relação a preço e sortimento, por exemplo;

- Conflitos de canais: muitas vezes estes canais são unidades de negócios separadas, como as lojas físicas e o e-commerce, que não se conversam e não compartilham das mesmas informações, políticas, metas e incentivos às equipes de vendas;

- Processos engessados: processos antigos, dependentes de pessoas ou desenvolvidos pensando em canais específicos podem não funcionar ou fluir bem para novos canais;

- Sistemas não integrados: muitas vezes os sistemas de gestão (back-office) ou de linha de frente (front-end) são legados ou distintos e não conversam nos diferentes canais físicos e digitais, dificultando a integração e gerando conflitos de informação;

- Logística deficitária: devido à dimensão territorial e infraestrutura insuficiente, são grandes as deficiências logísticas no Brasil; elas impactam a qualidade dos serviços de entrega e encarecem o frete para os varejistas e consumidores;

- Recursos financeiros: os investimentos necessários para integração multicanal são considerados altos, especialmente em tecnologia, logística e qualificação de pessoas; 
- Legislação: o complexo e caro sistema tributário brasileiro dificulta, e muitas vezes inviabiliza, a circulação de produtos entre os diversos canais.

Sobre o tema Casos e Melhoras Práticas, a tabela a seguir mostra a contagem de indicadores (frases ou citações) que compõem cada proposição.

Tabela 10 - Casos e Melhores Práticas

\begin{tabular}{|c|c|c|c|c|c|c|}
\hline Profissionais & T8.P1 & T8.P2 & T8.P3 & T8.P4 & T8.P5 & T8.P6 \\
\cline { 2 - 7 } Entrevistados & $\begin{array}{c}\text { Magazine } \\
\text { Luiza }\end{array}$ & $\begin{array}{c}\text { Pão de } \\
\text { Açúcar }\end{array}$ & $\begin{array}{c}\text { Livraria } \\
\text { Saraiva }\end{array}$ & $\begin{array}{c}\text { Natura } \\
\text { Cosmét. }\end{array}$ & $\begin{array}{c}\text { Outros } \\
\text { Casos }\end{array}$ & $\begin{array}{c}\text { Casos } \\
\text { Internac. }\end{array}$ \\
\hline Entrevistado 1 & 1 & 1 & - & - & - & - \\
\hline Entrevistado 2 & 1 & 1 & - & - & 1 & - \\
\hline Entrevistado 3 & 2 & 1 & - & - & 3 & 2 \\
\hline Entrevistado 4 & 1 & 1 & - & - & 1 & 2 \\
\hline Entrevistado 5 & - & 1 & - & - & - & - \\
\hline Entrevistado 6 & - & - & 1 & - & 4 & 2 \\
\hline Entrevistado 7 & - & - & - & - & - & 1 \\
\hline Entrevistado 8 & - & - & - & 1 & - & 1 \\
\hline Entrevistado 9 & 1 & - & - & - & - & - \\
\hline Entrevistado 10 & 1 & - & - & - & 2 & - \\
\hline Entrevistado 11 & 1 & - & 1 & 1 & - & - \\
\hline Entrevistado 12 & - & - & - & - & - & 1 \\
\hline Entrevistado 13 & - & - & 1 & - & 1 & - \\
\hline Total Indicadores & $\mathbf{8}$ & $\mathbf{5}$ & $\mathbf{3}$ & $\mathbf{2}$ & $\mathbf{1 2}$ & $\mathbf{9}$ \\
\hline \% Indicadores & $20,5 \%$ & $12,8 \%$ & $7,7 \%$ & $5,1 \%$ & $30,8 \%$ & $23,1 \%$ \\
\hline Total Entrevistados & $\mathbf{7}$ & $\mathbf{5}$ & $\mathbf{3}$ & $\mathbf{2}$ & $\mathbf{6}$ & $\mathbf{6}$ \\
\hline
\end{tabular}

Fonte: Elaborado pelo autor.

Quanto às melhores práticas, apenas quatro organizações foram lembradas por pelo menos dois entrevistados como casos de atuação no varejo multicanal. A mais citada foi Magazine Luíza (7;8), seguida por Pão de Açúcar (5;5). Livraria Saraiva (3;3) e Natura Cosméticos $(2 ; 2)$ foram citadas por poucos especialistas. Também houveram citações de outros casos nacionais $(6 ; 12)$ e alguns casos internacionais $(6 ; 9)$.

Os entrevistados consideram que não existe um grande caso de sucesso na integração de canais no Brasil, mas algumas organizações parecem ter boas práticas que podem ser seguidas e 
indicam um caminho virtuoso em relação ao omnichannel. Um dos grandes entraves são as políticas de precificação de produtos e remuneração dos vendedores para loja e e-commerce. $\mathrm{O}$ ideal é que o varejista apresente a mesma política de precificação, promoções, sortimento, segmentação de clientes, comunicação e réguas de relacionamento, independente do canal.

As principais organizações de varejo citadas foram:

- Magazine Luiza (7;8): apresenta algumas iniciativas de orientação para clientes e atuação omnichannel, como a criação de laboratório de inovação digital respondendo direto para a presidência, vendas por aplicativo, vendas em redes sociais (social commerce) e e-commerce dentro das lojas;

- Grupo Pão de Açúcar (5;5): apesar de ser multiformato no varejo supermercadista, apresenta cultura de inovação multicanal, com muitas iniciativas, especialmente na bandeira Pão de Açúcar, com aplicativos móveis, retirada na loja e totens interativos em parceria com a indústria. A bandeira Extra possui um projeto piloto de entrega de produtos em loja física, por meio de pick-up stores ou lockers. Outros varejistas estão trabalhando na mesma iniciativa;

- Livraria Saraiva (3;3): retirada e troca de livros e outros produtos nas mais de 100 lojas espalhadas pelo Brasil, compra de livros digitais por meio de e-reader (dispositivo eletrônico para leitura digital, compra e entrega de livros no mesmo dia, algumas promoções válidas para loja física e $e$-commerce.

Aparentemente, varejistas com maiores receitas apresentam mais inovações multicanal, pois tem mais facilidade pelo tamanho e disponibilidade de recursos, embora, em tese, varejistas de pequeno e médio porte tenham mais flexibilidade, agilidade e controle dos canais.

\subsection{Processos de Gestão de Clientes}

Neste tópico, são analisadas as respostas sobre as seguintes categorias:

(i) Processo de desenvolvimento da estratégia;

(ii) Processo de gestão da informação / conhecimento dos clientes;

(iii) Processo de criação de valor / experiência dos clientes;

(iv) Processo de avaliação de desempenho e resultados. 
O objetivo é obter diretrizes implementação dos principais processos da estratégia de gestão de clientes, considerando cenário do varejo multicanal analisado no tópico anterior.

\subsubsection{Processo de Desenvolvimento da Estratégia}

Para o processo de desenvolvimento da estratégia de gestão de clientes, foram avaliados três blocos temáticos e suas proposições citadas nas entrevistas: T9 - Alinhamento com Estratégia e Objetivos Organizacionais; T10 - Envolvimento na Estratégia de Gestão de Clientes; T11 Principais Mudanças e Impactos nas Organizações.

A tabela a seguir contém a contagem de indicadores (frases ou citações) que compõem cada proposição do tema Alinhamento com Estratégia e Objetivos Organizacionais, visando entender as similaridades e diferenças de opiniões dos entrevistados.

Tabela 11 - Alinhamento com Estratégia e Objetivos Organizacionais

\begin{tabular}{|c|c|c|c|c|c|c|}
\hline \multirow{2}{*}{$\begin{array}{l}\text { Profissionais } \\
\text { Entrevistados }\end{array}$} & T9.P1 & T9.P2 & T9.P3 & T9.P4 & T9.P5 & T9.P6 \\
\hline & $\begin{array}{l}\text { Estratégia } \\
\text { Negócios }\end{array}$ & $\begin{array}{c}\text { Experiênc. } \\
\text { Clientes }\end{array}$ & $\begin{array}{c}\text { Conhecim. } \\
\text { Clientes }\end{array}$ & $\begin{array}{l}\text { Potencial. } \\
\text { Multicanal }\end{array}$ & $\begin{array}{c}\text { Receita } \\
\text { Rentabil. }\end{array}$ & $\begin{array}{r}\text { Satisfação } \\
\text { Fidelização }\end{array}$ \\
\hline Entrevistado 1 & 1 & - & 2 & 1 & - & - \\
\hline Entrevistado 2 & - & 1 & 2 & 1 & 1 & - \\
\hline Entrevistado 3 & 2 & 1 & 3 & 1 & 1 & - \\
\hline Entrevistado 4 & 3 & 1 & 2 & - & 2 & 1 \\
\hline Entrevistado 5 & 1 & 2 & 1 & - & - & - \\
\hline Entrevistado 6 & 1 & 1 & 1 & 1 & - & 1 \\
\hline Entrevistado 7 & 1 & 2 & - & - & 2 & 1 \\
\hline Entrevistado 8 & 1 & 2 & - & 1 & - & 1 \\
\hline Entrevistado 9 & 2 & 2 & 2 & - & - & 1 \\
\hline Entrevistado 10 & 1 & 1 & 1 & 1 & 2 & 3 \\
\hline Entrevistado 11 & 2 & 2 & 2 & - & - & - \\
\hline Entrevistado 12 & 1 & 1 & 1 & 1 & 2 & - \\
\hline Entrevistado 13 & 1 & 1 & - & 1 & 1 & - \\
\hline Total Indicadores & 17 & 17 & 17 & 8 & 11 & 8 \\
\hline$\%$ Indicadores & $21,8 \%$ & $21,8 \%$ & $21,8 \%$ & $10,3 \%$ & $14,1 \%$ & $10,3 \%$ \\
\hline Total Entrevistados & 12 & 12 & 10 & 8 & 7 & 6 \\
\hline
\end{tabular}


Gestão de clientes como estratégia de negócios $(12 ; 17)$ foi citada por quase todos os entrevistados, assim como estratégia para experiência dos clientes $(12 ; 17)$. Estratégia para conhecimento dos clientes $(10 ; 17)$ também foi bastante citada, seguida por estratégia para potencializar o multicanal $(8 ; 8)$. Quanto aos objetivos organizacionais, foram lembrados os objetivos de receita e rentabilização $(7 ; 11)$, objetivos de satisfação e fidelização $(6 ; 8)$.

A tabela a seguir contém a contagem de indicadores (frases ou citações) que compõem cada proposição do tema Envolvimento na Estratégia de Gestão de Clientes, visando entender as similaridades e diferenças de opiniões dos entrevistados.

Tabela 12 - Envolvimento na Estratégia de Gestão de Clientes

\begin{tabular}{|c|c|c|c|c|c|c|c|}
\hline \multirow{2}{*}{$\begin{array}{l}\text { Profissionais } \\
\text { Entrevistados }\end{array}$} & T10.P1 & T10.P2 & T10.P3 & T10.P4 & T10.P5 & T10.P6 & T10.P7 \\
\hline & $\begin{array}{l}\text { Liderança } \\
\text { A.Direção }\end{array}$ & $\begin{array}{l}\text { Liderança } \\
\text { Marketing }\end{array}$ & $\begin{array}{l}\text { Envolvim. } \\
\text { Marketing }\end{array}$ & $\begin{array}{l}\text { Liderança } \\
\text { CRM }\end{array}$ & $\begin{array}{l}\text { Envolvim. } \\
\text { Tecnolog. }\end{array}$ & $\begin{array}{l}\text { Envolvim. } \\
\text { Com. Op. }\end{array}$ & $\begin{array}{l}\text { Envolvim. } \\
\text { Rec.Hum. }\end{array}$ \\
\hline Entrevistado 1 & 1 & 1 & 1 & - & 1 & 2 & - \\
\hline Entrevistado 2 & 1 & - & 1 & - & - & - & - \\
\hline Entrevistado 3 & 1 & - & - & 1 & 1 & 1 & 1 \\
\hline Entrevistado 4 & - & 1 & - & 1 & - & - & 1 \\
\hline Entrevistado 5 & - & 1 & - & - & 1 & - & 1 \\
\hline Entrevistado 6 & 1 & - & 2 & 1 & 1 & 2 & 1 \\
\hline Entrevistado 7 & 1 & - & 1 & 1 & - & - & - \\
\hline Entrevistado 8 & 1 & - & - & 1 & - & - & - \\
\hline Entrevistado 9 & 1 & 1 & - & - & - & - & - \\
\hline Entrevistado 10 & - & - & 1 & - & - & 1 & - \\
\hline Entrevistado 11 & - & - & - & - & - & - & - \\
\hline Entrevistado 12 & - & 1 & - & - & - & - & - \\
\hline Entrevistado 13 & 1 & 1 & - & - & 1 & - & - \\
\hline Total Indicadores & 8 & 6 & 6 & 5 & 5 & 6 & 4 \\
\hline$\%$ Indicadores & $20,0 \%$ & $15,0 \%$ & $15,0 \%$ & $12,5 \%$ & $12,5 \%$ & $15,0 \%$ & $10,0 \%$ \\
\hline Total Entrevistados & 8 & 6 & 5 & 5 & 5 & 4 & 4 \\
\hline
\end{tabular}

Fonte: Elaborado pelo autor.

A liderança da presidência / alta direção $(8 ; 8)$ foi citada pela maioria dos entrevistados, seguida pela liderança de marketing $(6 ; 6)$ e envolvimento da área de marketing $(5 ; 6)$, cuja função é vista como primordial. Quase metade acredita que, para maior efetividade, a estratégia de gestão de clientes deve ter a liderança de CRM e Inteligência de Mercado (5;5), como uma 
área específica com status de diretoria ou vice-presidência, e ligação direta com a presidência da organização. Sobre outros envolvidos na estrtaégia, foram lembradas as áreas de Tecnologia da Informação (5;5), Comercial, Operações e Logística (4;6), e Recursos Humanos (4;4).

A tabela a seguir contém a contagem de indicadores (frases ou citações) que compõem cada proposição do tema Principais Mudanças e Impactos nas Organizações, visando entender as similaridades e diferenças de opiniões dos entrevistados.

Tabela 13 - Principais Mudanças e Impactos nas Organizações

\begin{tabular}{|c|c|c|c|c|c|c|}
\hline \multirow{2}{*}{$\begin{array}{l}\text { Profissionais } \\
\text { Entrevistados }\end{array}$} & T11.P1 & T11.P2 & T11.P3 & T11.P4 & T11.P5 & T11.P6 \\
\hline & $\begin{array}{l}\text { Pessoas } \\
\text { Cultura }\end{array}$ & $\begin{array}{c}\text { Gestão } \\
\text { Tecnolog. }\end{array}$ & $\begin{array}{c}\text { Gestão } \\
\text { Processos }\end{array}$ & $\begin{array}{l}\text { Govern. } \\
\text { KPIs }\end{array}$ & $\begin{array}{l}\text { Estrutura } \\
\text { Recursos }\end{array}$ & $\begin{array}{c}\text { Gestão } \\
\text { Analítica }\end{array}$ \\
\hline Entrevistado 1 & - & 1 & - & - & - & - \\
\hline Entrevistado 2 & 2 & 1 & - & - & - & - \\
\hline Entrevistado 3 & 2 & 3 & - & 1 & - & - \\
\hline Entrevistado 4 & 4 & 1 & - & 1 & - & 2 \\
\hline Entrevistado 5 & 4 & 3 & 1 & 2 & - & - \\
\hline Entrevistado 6 & 3 & 1 & 2 & - & 2 & 1 \\
\hline Entrevistado 7 & 1 & - & 1 & 1 & 1 & - \\
\hline Entrevistado 8 & 2 & 1 & - & - & 1 & - \\
\hline Entrevistado 9 & 2 & 2 & 2 & - & - & - \\
\hline Entrevistado 10 & - & - & - & - & - & - \\
\hline Entrevistado 11 & - & - & - & - & - & - \\
\hline Entrevistado 12 & 3 & 2 & - & - & 1 & - \\
\hline Entrevistado 13 & 1 & 1 & - & - & - & 1 \\
\hline Total Indicadores & 24 & 16 & 6 & 5 & 5 & 4 \\
\hline$\%$ Indicadores & $40,0 \%$ & $26,7 \%$ & $10,0 \%$ & $8,3 \%$ & $8,3 \%$ & $6,7 \%$ \\
\hline Total Entrevistados & 10 & 10 & 4 & 4 & 4 & 3 \\
\hline
\end{tabular}

Fonte: Elaborado pelo autor.

Para implementação da estratégia de gestão de clientes, a maioria dos especialistas citou mais de uma vez as mudanças em gestão de pessoas e cultura organizacional $(10 ; 24)$, que passaria de visão de canais de vendas e categorias de produtos para uma visão também de segmentos de consumidores, trazendo ganhos importantes para conhecimento, relacionamento e experiência dos clientes. A maioria também mencionou os impactos na gestão de tecnologia da informação $(10 ; 16)$ como função fundamental para o sucesso da implementação. Ainda foram lembradas 
por poucos entrevistados a gestão de processos de negócios $(4 ; 6)$, a governança da estratégia / gestão de indicadores $(4 ; 5)$, mudanças na estrutura e recursos organizacionais $(4 ; 5)$, e a gestão analítica e de inteligência de negócios $(3 ; 4)$.

\subsubsection{Processo de Gestão da Informação / Conhecimento dos Clientes}

Para o processo de desenvolvimento da estratégia de gestão de clientes, foram avaliados três blocos temáticos e suas proposições citadas nas entrevistas: T12 - Captura de Dados e Criação de Visão Única; T13 - Análises e Segmentação da Base de Consumidores.

A tabela a seguir contém a contagem de indicadores (frases ou citações) que compõem cada proposição do tema Captura de Dados e Criação de Visão Única, com objetivo de entender as similaridades e diferenças de opiniões dos entrevistados.

Tabela 14 - Captura de Dados e Criação de Visão Única

\begin{tabular}{|c|c|c|c|c|c|c|c|}
\hline \multirow{2}{*}{$\begin{array}{c}\text { Profissionais } \\
\text { Entrevistados }\end{array}$} & T12.P1 & T12.P2 & T12.P3 & T12.P4 & T12.P5 & T12.P6 & T12.P7 \\
\hline & $\begin{array}{c}\text { Canais } \\
\text { Digitais }\end{array}$ & $\begin{array}{l}\text { Canais } \\
\text { Físicos }\end{array}$ & $\begin{array}{l}\text { Databases } \\
\text { Desestrut. }\end{array}$ & $\begin{array}{l}\text { Pesquisas } \\
\text { Físicos }\end{array}$ & $\begin{array}{l}\text { Pesquisas } \\
\text { Digitais }\end{array}$ & $\begin{array}{c}\text { Gestão } \\
\text { Terceiros }\end{array}$ & $\begin{array}{l}\text { Programas } \\
\text { Fidelidade }\end{array}$ \\
\hline Entrevistado 1 & 2 & 2 & - & 1 & - & - & 1 \\
\hline Entrevistado 2 & 1 & - & 1 & 1 & 1 & 1 & - \\
\hline Entrevistado 3 & - & 1 & 1 & - & - & 1 & - \\
\hline Entrevistado 4 & - & - & 1 & 2 & - & - & - \\
\hline Entrevistado 5 & 1 & - & - & 2 & - & 1 & - \\
\hline Entrevistado 6 & 2 & 3 & 1 & 1 & 2 & 1 & - \\
\hline Entrevistado 7 & 1 & 1 & - & - & 1 & - & 1 \\
\hline Entrevistado 8 & 1 & 1 & 1 & - & - & - & - \\
\hline Entrevistado 9 & 1 & 1 & - & 1 & 1 & - & - \\
\hline Entrevistado 10 & 1 & 1 & 1 & 2 & 2 & - & - \\
\hline Entrevistado 11 & 1 & 1 & 1 & - & - & 1 & - \\
\hline Entrevistado 12 & 1 & 1 & 1 & - & - & - & - \\
\hline Entrevistado 13 & 1 & 1 & 1 & - & - & - & - \\
\hline Total Indicadores & 13 & 13 & 9 & 10 & 7 & 5 & 2 \\
\hline$\%$ Indicadores & $22,0 \%$ & $22,0 \%$ & $15,3 \%$ & $16,9 \%$ & $11,9 \%$ & $8,5 \%$ & $3,4 \%$ \\
\hline Total Entrevistados & 11 & 10 & 9 & 7 & 5 & 5 & 2 \\
\hline
\end{tabular}


As transações e interações de canais digitais (11;13), como e-commerce, foram considerados como primordiais pela maioria dos especialistas para criação de visão única de clientes, assim como as transações e interações de canais físicos (10;13). As bases de dados desestruturados $(9 ; 9)$, com origem na internet e redes sociais, por exemplo, também foram bastante lembradas, seguidas pelas pesquisas realizadas com clientes de canais físicos $(7 ; 10)$ e digitais $(5 ; 7)$. A gestão de base de clientes por terceiros $(5 ; 5)$ foi mencionada por alguns como uma opção para acelerar a estruturação da visão única. $\mathrm{E}$ os dados de programas de relacionamento / fidelidade $(2 ; 2)$ também foram citados, embora com frequência muito baixa.

A tabela a seguir contém a contagem de indicadores (frases ou citações) que compõem cada proposição do tema Análises e Segmentação da Base de Consumidores, visando entender as similaridades e diferenças de opiniões dos entrevistados.

Tabela 15 - Análises e Segmentação da Base de Consumidores

\begin{tabular}{|c|c|c|c|c|c|}
\hline Profissionais & T13.P1 & T13.P2 & T13.P3 & T13.P4 & T13.P5 \\
\cline { 2 - 6 } Entrevistados & $\begin{array}{c}\text { Comport. } \\
\text { Compra }\end{array}$ & $\begin{array}{c}\text { Canais de } \\
\text { Vendas }\end{array}$ & $\begin{array}{c}\text { Modelos } \\
\text { Preditivos }\end{array}$ & $\begin{array}{c}\text { Valor de } \\
\text { Consumo }\end{array}$ & $\begin{array}{c}\text { Necessi- } \\
\text { dades }\end{array}$ \\
\hline Entrevistado 1 & 1 & 2 & - & 1 & - \\
\hline Entrevistado 2 & - & - & 1 & - & - \\
\hline Entrevistado 3 & 1 & - & 1 & 1 & - \\
\hline Entrevistado 4 & 1 & 1 & 2 & - & - \\
\hline Entrevistado 5 & 1 & 1 & - & 1 & - \\
\hline Entrevistado 6 & 2 & 1 & 2 & - & - \\
\hline Entrevistado 7 & 1 & 1 & - & - & - \\
\hline Entrevistado 8 & 1 & 1 & 1 & - & - \\
\hline Entrevistado 9 & 2 & 1 & - & - & 1 \\
\hline Entrevistado 10 & 1 & 1 & 2 & - & 1 \\
\hline Entrevistado 11 & 1 & 1 & - & - & 1 \\
\hline Entrevistado 12 & - & - & - & - & - \\
\hline Entrevistado 13 & 1 & 1 & 1 & - & - \\
\hline Total Indicadores & $\mathbf{1 3}$ & $\mathbf{1 1}$ & $\mathbf{1 0}$ & $\mathbf{3}$ & $\mathbf{3}$ \\
\hline \% Indicadores & $32,5 \%$ & $27,5 \%$ & $25,0 \%$ & $7,5 \%$ & $7,5 \%$ \\
\hline Total Entrevistados & $\mathbf{1 1}$ & $\mathbf{1 0}$ & $\mathbf{7}$ & $\mathbf{3}$ & $\mathbf{3}$ \\
\hline
\end{tabular}

Fonte: Elaborado pelo autor. 
A segmentação comportamental de compra $(11 ; 13)$ foi lembrada por todos os entrevistados, além da segmentação por canais de vendas $(10 ; 11)$, que permite avaliar as preferências e hábitos em relação ao multicanal. Os modelos preditivos de comportamento $(7 ; 10)$, como composição da cesta de compras, próximas compras e fidelização, também foram observados pela maioria. Embora importantes, poucos especialistas citaram os modelos de segmentação por valor de consumo $(3 ; 3)$ e segmentação por necessidades / estilo de vida $(3 ; 3)$.

\subsubsection{Processo de Criação de Valor / Experiência dos Clientes}

Para o processo de desenvolvimento da estratégia de gestão de clientes, foram avaliados três blocos temáticos e suas proposições citadas nas entrevistas: T14 - Planos de Interação com Segmentos de Consumidores; T15 - Desenvolvimento de Programas de Relacionamento / Fidelidade; T16 - Personalização de Produtos, Serviços e Interações.

A tabela a seguir contém a contagem de indicadores (frases ou citações) que compõem cada proposição do tema Planos de Interação com Segmentos de Consumidores, com objetivo de entender as similaridades e diferenças de opiniões dos entrevistados. 
Tabela 16 - Planos de Interação com Segmentos de Consumidores

\begin{tabular}{|c|c|c|c|c|c|}
\hline \multirow{2}{*}{$\begin{array}{c}\text { Profissionais } \\
\text { Entrevistados }\end{array}$} & T14.P1 & T14.P2 & T14.P3 & T14.P4 & T14.P5 \\
\hline & $\begin{array}{c}\text { Gestão } \\
\text { Campanha }\end{array}$ & $\begin{array}{l}\text { Relevância } \\
\text { Interações }\end{array}$ & $\begin{array}{l}\text { Canais } \\
\text { Físicos }\end{array}$ & $\begin{array}{l}\text { Canais } \\
\text { Digitais }\end{array}$ & $\begin{array}{l}\text { Política } \\
\text { Impactos }\end{array}$ \\
\hline Entrevistado 1 & 2 & 3 & 2 & - & - \\
\hline Entrevistado 2 & 2 & 1 & - & - & - \\
\hline Entrevistado 3 & 2 & - & 2 & 2 & 1 \\
\hline Entrevistado 4 & 1 & - & - & 1 & 3 \\
\hline Entrevistado 5 & 1 & - & 1 & 1 & 1 \\
\hline Entrevistado 6 & 1 & 1 & - & - & 1 \\
\hline Entrevistado 7 & - & 1 & 1 & - & - \\
\hline Entrevistado 8 & 2 & 1 & - & 1 & - \\
\hline Entrevistado 9 & - & - & 1 & - & - \\
\hline Entrevistado 10 & 1 & 3 & - & 1 & - \\
\hline Entrevistado 11 & - & 3 & 1 & 1 & 1 \\
\hline Entrevistado 12 & 2 & - & 2 & - & 1 \\
\hline Entrevistado 13 & - & - & - & 2 & 1 \\
\hline Total Indicadores & 14 & 13 & 10 & 9 & 9 \\
\hline$\%$ Indicadores & $34,1 \%$ & $31,7 \%$ & $24,4 \%$ & $22,0 \%$ & $22,0 \%$ \\
\hline Total Entrevistados & 9 & 7 & 7 & 7 & 7 \\
\hline
\end{tabular}

Sobre os planos de interação, foi citada pela maioria a gestão de campanhas e réguas de relacionamento $(9 ; 14)$ como uma oportunidade para fazer impactos planejados, recorrentes e automatizados sobre a base de consumidores, por diversos canais disponíveis, como malas diretas, e-mails, mobile, site na internet, etc. Os especialistas lembraram a importância de manter a relevância na interações e campanhas $(7 ; 13)$, ou seja, tratem de assuntos e ofertas de interesse do consumidor. Para maior efetividade, é importante manter planos de interação nos canais físicos $(7 ; 10)$ e canais digitais $(7 ; 10)$, por ciclo de vida e segmentos de consumidores, conforme foi lembrado pela maioria, que também ressaltou a necessidade de ter uma política de impactos / disparos de ações (7;9) para base, como, por exemplo, tipos e quantidade de emails a serem disparados para os consumidores em determinado período de tempo.

A tabela a seguir contém a contagem de indicadores (frases ou citações) que compõem cada proposição do tema de Desenvolvimento de Programas de Relacionamento / Fidelidade, visando entender as similaridades e diferenças de opiniões dos entrevistados. 
Tabela 17 - Desenho de Programas de Relacionamento / Fidelidade

\begin{tabular}{|c|c|c|}
\hline \multirow{2}{*}{$\begin{array}{l}\text { Profissionais } \\
\text { Entrevistados }\end{array}$} & T15.P1 & T15.P2 \\
\hline & $\begin{array}{c}\text { Programas } \\
\text { Próprios }\end{array}$ & $\begin{array}{c}\text { Programas } \\
\text { Terceiros }\end{array}$ \\
\hline Entrevistado 1 & 1 & - \\
\hline Entrevistado 2 & - & - \\
\hline Entrevistado 3 & 1 & 1 \\
\hline Entrevistado 4 & 1 & - \\
\hline Entrevistado 5 & 1 & 1 \\
\hline Entrevistado 6 & 3 & - \\
\hline Entrevistado 7 & 1 & - \\
\hline Entrevistado 8 & - & - \\
\hline Entrevistado 9 & 1 & 1 \\
\hline Entrevistado 10 & - & 2 \\
\hline Entrevistado 11 & 2 & - \\
\hline Entrevistado 12 & 2 & - \\
\hline Entrevistado 13 & - & - \\
\hline Total Indicadores & 13 & 5 \\
\hline$\%$ Indicadores & $31,7 \%$ & $12,2 \%$ \\
\hline Total Entrevistados & 9 & 4 \\
\hline
\end{tabular}

Fonte: Elaborado pelo autor.

O desenvolvimento e gestão de programas de fidelidade próprios $(9 ; 13)$ foi mencionado pela maioria dos especialistas como alternativa para identificar e conhecer melhor os consumidores, aprofundar o relacionamento e obter, dessa forma, maior fidelidade nas compras. Alguns entrevistados lembraram a possibilidade de participação em programas de terceiros $(4 ; 5)$, conhecidos como programas de coalizão, como Multiplus, Smiles, Dotz e Netpoints.

A tabela a seguir contém a contagem de indicadores (frases ou citações) que compõem cada proposição do tema Personalização de Produtos, Serviços e Interações, visando entender as similaridades e diferenças de opiniões dos entrevistados. 
Tabela 18 - Personalização de Produtos, Serviços e Interações

\begin{tabular}{|c|c|c|c|c|c|}
\hline Profissionais & T16.P1 & T16.P2 & T16.P3 & T16.P4 & T16.P5 \\
\cline { 2 - 7 } & $\begin{array}{c}\text { Canais de } \\
\text { Vendas }\end{array}$ & $\begin{array}{c}\text { Ofertas } \\
\text { Produtos }\end{array}$ & $\begin{array}{c}\text { Processos } \\
\text { Atendim. }\end{array}$ & $\begin{array}{c}\text { Relacion. } \\
\text { Comunic. }\end{array}$ & $\begin{array}{c}\text { Cocriação } \\
\text { Produtos }\end{array}$ \\
\hline Entrevistado 1 & 2 & - & - & - & 1 \\
\hline Entrevistado 2 & 1 & 1 & 1 & - & 1 \\
\hline Entrevistado 3 & 2 & 1 & - & 2 & - \\
\hline Entrevistado 4 & 4 & - & - & 1 & - \\
\hline Entrevistado 5 & 1 & - & - & - & 1 \\
\hline Entrevistado 6 & 1 & 1 & 2 & 1 & - \\
\hline Entrevistado 7 & - & - & - & - & - \\
\hline Entrevistado 8 & 1 & - & - & - & - \\
\hline Entrevistado 9 & - & - & 1 & - & - \\
\hline Entrevistado 10 & - & 1 & 1 & - & - \\
\hline Entrevistado 11 & 2 & 2 & 1 & 1 & - \\
\hline Entrevistado 12 & 1 & - & - & - & 2 \\
\hline Entrevistado 13 & 1 & 1 & - & - & - \\
\hline Total Indicadores & $\mathbf{1 6}$ & $\mathbf{7}$ & $\mathbf{6}$ & $\mathbf{5}$ & $\mathbf{5}$ \\
\hline \% Indicadores & $41,0 \%$ & $17,9 \%$ & $15,4 \%$ & $12,8 \%$ & $12,8 \%$ \\
\hline Total Entrevistados & $\mathbf{1 0}$ & $\mathbf{6}$ & $\mathbf{5}$ & $\mathbf{4}$ & $\mathbf{4}$ \\
\hline
\end{tabular}

Fonte: Elaborado pelo autor.

A personalização é uma forma de criar valor para os consumidores, permitindo uma relação próxima e individualizada. A possibilidade de personalização de canais de vendas $(10 ; 16)$ preferidos, a partir do histórico de consumo, foi mencionada por quase todos os entrevistados. Também foram citados por alguns especialistas a personalização de ofertas de produtos $(6 ; 7)$, com recomendações a partir do histórico de compra de outros consumidores, e a personalização de processos de atendimento (5;6), a partir de preferências e interações passadas; bem como a personalização de relacionamento e comunicação (4;5), com desenho de campanhas a partir de dados variáveis da base com visão única de clientes. O processo de cocriação de produtos e serviços $(4 ; 5)$ foi lembrado por alguns como estratégia para desenvolvimento em conjunto com os consumidores, a partir de informações e feedbacks espontâneos ou estimulados. 


\subsubsection{Processo de Avaliação de Desempenho e Resultados}

Para o processo de desenvolvimento da estratégia de gestão de clientes, foram avaliados três blocos temáticos e suas proposições citadas nas entrevistas: T17 - Métricas de Desempenho e Avaliação de Resultados; T18 - Resultados e Criação de Valor para Acionistas.

A tabela a seguir contém a contagem de indicadores (frases ou citações) que compõem cada proposição do tema Métricas de Desempenho e Avaliação de Resultados, visando entender as similaridades e diferenças de opiniões dos entrevistados.

Tabela 19 - Métricas de Desempenho e Avaliação de Resultados

\begin{tabular}{|c|c|c|c|c|c|c|c|}
\hline \multirow{2}{*}{$\begin{array}{l}\text { Profissionais } \\
\text { Entrevistados }\end{array}$} & T17.P1 & T17.P2 & T17.P3 & T17.P4 & T17.P5 & T17.P6 & T17.P7 \\
\hline & $\begin{array}{c}\text { Retorno } \\
\text { Campanha }\end{array}$ & $\begin{array}{c}\text { Satisfação } \\
\text { Fidelização }\end{array}$ & $\begin{array}{l}\text { Visão de } \\
\text { Canais }\end{array}$ & $\begin{array}{l}\text { Visão de } \\
\text { Clientes }\end{array}$ & $\begin{array}{l}\text { Receita } \\
\text { Margem }\end{array}$ & $\begin{array}{c}\text { Comport. } \\
\text { Compra }\end{array}$ & $\begin{array}{c}\text { Eficiência } \\
\text { Custos }\end{array}$ \\
\hline Entrevistado 1 & 1 & 2 & 2 & 1 & - & 1 & 1 \\
\hline Entrevistado 2 & - & - & 2 & - & - & - & - \\
\hline Entrevistado 3 & 1 & - & - & - & - & - & - \\
\hline Entrevistado 4 & - & - & - & - & - & - & - \\
\hline Entrevistado 5 & - & - & 2 & 1 & - & 1 & - \\
\hline Entrevistado 6 & 3 & 1 & 1 & 1 & 1 & - & - \\
\hline Entrevistado 7 & 1 & - & - & - & - & - & - \\
\hline Entrevistado 8 & 1 & 1 & 2 & 1 & 2 & - & 1 \\
\hline Entrevistado 9 & 1 & 4 & 2 & 2 & 1 & 2 & 1 \\
\hline Entrevistado 10 & 2 & - & - & - & - & - & - \\
\hline Entrevistado 11 & 1 & 3 & - & - & 1 & 1 & 2 \\
\hline Entrevistado 12 & 1 & - & - & - & - & - & - \\
\hline Entrevistado 13 & - & 1 & - & 1 & 2 & 1 & - \\
\hline Total Indicadores & 12 & 12 & 11 & 7 & 7 & 6 & 5 \\
\hline$\%$ Indicadores & $20,0 \%$ & $20,0 \%$ & $18,3 \%$ & $11,7 \%$ & $11,7 \%$ & $10,0 \%$ & $8,3 \%$ \\
\hline Total Entrevistados & 9 & 6 & 6 & 6 & 5 & 5 & 4 \\
\hline
\end{tabular}

Fonte: Elaborado pelo autor.

Dentre as métricas de desempenho, a maioria dos entrevistados citou o retorno de campanhas de relacionamento $(9 ; 12)$ como uma forma de avaliar os resultados e a efetividade da estratégia de gestão de clientes. Também foram lembrados pelos entrevistados, com muitas citações, os indicadores de satisfação e fidelização $(6 ; 12)$, e a avaliação de performance / visão por canais 
de vendas $(6 ; 11)$. Com menor quantidade de citações, foram mencionados a avaliação de performance / visão por segmentos de clientes $(6 ; 7)$, além de indicadores de vendas, receita e margem $(5 ; 7)$, indicadores de comportamento de compra $(5 ; 6)$ e indicadores de eficiência operacional e custos $(4 ; 5)$.

A tabela a seguir contém a contagem de indicadores (frases ou citações) que compõem cada proposição do tema Resultados e Criação de Valor para Acionistas, visando entender as similaridades e diferenças de opiniões dos entrevistados.

Tabela 20 - Resultados e Criação de Valor para Acionistas

\begin{tabular}{|c|c|c|c|c|c|c|}
\hline \multirow{2}{*}{$\begin{array}{c}\text { Profissionais } \\
\text { Entrevistados }\end{array}$} & $\begin{array}{c}\text { T18.P1 } \\
\text { Rendas }\end{array}$ & $\begin{array}{c}\text { T18.P2 } \\
\text { Recerita }\end{array}$ & T18.P3 & T18.P4 & T18.P5 & T18.P6 \\
\hline Entrevistado 1 & - & - & 1 & - & 1 & 1 \\
\hline Entrevistado 2 & 2 & 1 & - & - & - & 1 \\
\hline Entrevistado 3 & - & - & 1 & - & - & - \\
\hline Entrevistado 4 & 2 & - & - & - & - & - \\
\hline Entrevistado 5 & - & 1 & - & - & 1 & - \\
\hline Entrevistado 6 & - & 1 & - & 1 & 1 & - \\
\hline Entrevistado 7 & 1 & - & - & 1 & - & - \\
\hline Entrevistado 8 & 1 & 1 & 1 & - & 1 & - \\
\hline Entrevistado 9 & - & 1 & - & - & - & 1 \\
\hline Entrevistado 10 & - & 1 & 1 & 1 & - & - \\
\hline Entrevistado 11 & - & - & - & - & - & - \\
\hline Entrevistado 12 & 1 & - & - & - & - & 1 \\
\hline Entrevistado 13 & 1 & - & - & 1 & - & - \\
\hline Total Indicadores & $\mathbf{8}$ & $\mathbf{6}$ & $\mathbf{4}$ & $\mathbf{4}$ & $\mathbf{4}$ & $\mathbf{4}$ \\
\hline \% Indicadores & $26,7 \%$ & $20,0 \%$ & $13,3 \%$ & $13,3 \%$ & $13,3 \%$ & $13,3 \%$ \\
\hline Total Entrevistados & $\mathbf{6}$ & $\mathbf{6}$ & $\mathbf{4}$ & $\mathbf{4}$ & $\mathbf{4}$ & $\mathbf{4}$ \\
\hline & & Fonte: Elaborado pelo autor. & & & - \\
\hline
\end{tabular}

Em relação ao valor para os acionistas, o aumento de volume de vendas e receita $(6 ; 8)$ aparece como a forma mais citada de justificar a adoção da estratégia de gestão de clientes, considerando que o acionista é muito orientado a buscar resultados de curto prazo. Nesse sentido, a geração de experiência multicanal $(6 ; 6)$ e a criação de diferencial competitivo $(4 ; 4)$ também foram proposições citadas por alguns entrevistados, assim como aumento de margem / rentabilidade 
$(4 ; 4)$ e geração de conhecimento dos clientes (4;4). Além disso, a parceria com fornecedores / indústria $(4 ; 4)$ foi mencionada como uma possibilidade de compartilhar informações sobre os consumidores e executar iniciativas em conjunto.

\subsection{Diretrizes para Implementação da Estratégia}

Como conclusão da análise e contribuição para a prática dos negócios, a seguir é apresentado um resumo das principais diretrizes identificadas na pesquisa exploratória com especialistas, validadas à luz da experiência e do referencial teórico, visando a implementação bem-sucedida de estratégia de gestão de clientes em organizações de varejo multicanal.

\section{Estratégia e Objetivos Organizacionais:}

- A gestão de clientes deve ser entendida como estratégia de negócios para as organizações de varejo, podendo criar diferenciais competitivos em cenário de grande competição;

- A estratégia de gestão de clientes permite a entrega de uma melhor experiência de consumo, por meio do conhecimento mais profundo dos consumidores e da potencialização dos múltiplos canais de venda, pós-venda, relacionamento e comunicação;

- Como principais objetivos, a gestão de clientes deve contribuir para o aumento da receita e rentabilidade da organização de varejo, e para a satisfação e fidelização dos consumidores.

\section{Envolvimento das Áreas na Estratégia:}

- A presidência / alta direção deve liderar a estratégia de gestão de clientes ou apoiar a área de marketing nesta liderança, pois esta última está mais próxima dos interesses dos consumidores. Uma alternativa é criar uma área específica de CRM e Inteligência de Mercado para liderar a estratégia de gestão de clientes, com bastante envolvimento da área marketing;

- Outras áreas da organização de varejo devem ser envolvidas na estratégia, principalmente Tecnologia da Informação, Comercial, Operações, Logística e Recursos Humanos.

\section{Mudanças e Impactos na Organização:}

- O principal impacto está na gestão de pessoas e cultura organizacional, envolvendo desde a definição do perfil das pessoas para contratação até capacitação, incentivos e comunicação; 
- A gestão da tecnologia da informação e a gestão de processos de negócios são outras funções bastante impactadas, pois envolvem muitas atividades da estratégia de gestão de clientes;

- Para assegurar a execução e os resultados da estratégia, devem ser definidas políticas de governança, como o acompanhamento de iniciativas, e controle de indicadores (KPIs);

- A estrutura e os recursos da organização, como financeiros, operacionais e humanos devem estar adequados para viabilizar a entrega das iniciativas da estratégia de gestão de clientes;

- A gestão analítica (analytics) e de inteligência de negócios (business intelligence) devem suportar a estratégia, por meio de informações e insights gerados em análise de dados.

\section{Estruturação da Visão Única de Clientes:}

- Para compor a visão única do consumidor, independente do canal de compra, devem ser capturados os dados das transações (aquisições de produtos e serviços) dos canais digitais e físicos, bem como os dados das interações (atendimentos e campanhas de relacionamento);

- A captura de dados desestruturados (big data), espelhados pela internet, é algo muito novo e avançado para o varejo. Por isso, é considerado importante, mas não prioritário;

- Pesquisas com clientes em canais físicos e digitais é outra origem de dados considerada, bem como o enriquecimento com dados de terceiros e de programas de fidelidade.

\section{Segmentação da Base de Consumidores:}

- As análises e segmentações recomendadas para a estratégia de gestão de clientes no varejo multicanal são por comportamento de compra, como frequência, valor e data da compra, e por canais de vendas, permitindo o entendimento de diferentes perfis de consumidores;

- Modelos preditivos de comportamento, a partir de técnicas estatísticas mais apuradas, são recomendados para um estágio mais avançado da estratégia, incluindo modelos para oferta de novos produtos e prevenção de perda de clientes;

- Outras formas de segmentação são por valor de consumo em um determinado período de tempo, e por necessidades dos consumidores, alinhadas aos diversos estilos de vida.

\section{Planos de Interação com Consumidores:}

- Planejamento e gestão de campanhas de relacionamento, incluindo réguas automatizadas por diversos canais, é uma tática recomendada para estabelecer interações sistemáticas com os consumidores; 
- As interações com os consumidores devem ser relevantes, tanto na abordagem quanto na oferta de produtos serviços, considerando os segmentos definidos e outras informações;

- Os planos de interação com consumidores devem ser estruturados tanto para canais físicos, como lojas e catálogos, quanto para os digitais, como sites e e-mails, conforme a pertinência;

- É importante prever política de impactos sobre a base de consumidores, incluindo disparos de ações, como e-mail, visando evitar desgastes e otimizar resultados;

\section{Programas de Relacionamento / Fidelidade:}

- A estratégia de gestão de clientes deve considerar o planejamento e a gestão de programas de fidelidade prioritários, nos modelos de relacionamento, reconhecimento e recompensas, visando à obtenção de novos dados sobre os consumidores e oportunidades de interação;

- Programas de fidelidade geridos por terceiros e que agregam várias marcas, conhecidos por programas de coalizão, constituem opção prática e rápida para implementação e operação de um programa. Porém, geram menor impacto para a marca, e menor possibilidade de gestão e controle sobre informações e interações.

\section{Personalização de Produtos, Serviços e Interações:}

- Para maior relevância para o consumidor e resultados para a organização, considerando os dados coletados e o conhecimento obtido, pode-se personalizar canais de vendas, ofertas de produtos e serviços, processos de atendimento e ações de relacionamento, dentre outros;

- Outra opção é estimular a criação de produtos e serviços em conjunto com o consumidor, em processo de cocriação, por meio dos canais físicos e digitais disponíveis ou novos.

\section{Indicadores e Avaliação de Resultados:}

- O retorno de campanhas de relacionamento com métricas de engajamento ou conversão em vendas, por exemplo, comparado a grupos de controle, são formas de avaliar resultados da estratégia de gestão de clientes no curto prazo;

- Para avaliação dos resultados sobre clientes no médio e longo prazos, deve-se acompanhar a evolução de indicadores de satisfação e fidelização, além de comportamento de compra, como "recência" de compra, valor de compra, frequência e ticket médio;

- Em relação à avaliação dos resultados do negócio como um todo, impactado pela estratégia de gestão de clientes, deve-se acompanhar os indicadores de volume de vendas, receita e margem, além de métricas de eficiência operacional e gestão de custos; 
- As métricas e resultados devem ser acompanhados na visão por canais de vendas, físicos e digitais, e na visão por segmentos de consumidores definidos para a estratégia.

\section{Criação de Valor para Acionistas:}

- Para avaliação dos resultados da estratégia de gestão de clientes, os acionistas consideram os impactos no volume de vendas e receita, bem como na rentabilidade dos negócios;

- A criação de diferencial competitivo, por meio da estratégia de gestão de clientes, também é percebida como um aspecto de geração de valor para os acionistas;

- A geração da experiência multicanal positiva e o aprofundamento do conhecimento sobre os consumidores, outras formas de demonstrar valor para os acionistas;

- A gestão de clientes pode estimular novas barganhas e parcerias com fornecedores, como a indústria de bens de consumo, que podem ter interesse em adquirir o conhecimento gerado sobre os consumidores ou investir em ações de relacionamento, criando mais valor.

A figura a seguir consolida as diretrizes e os principais aprendizados da pesquisa e pode servir como referência para organizações de varejo que desejam desenvolver um plano de intervenção visando a implementação da estratégia de gestão de clientes em ambiente multicanal. 
Figura 7 - Consolidação das diretrizes para implementação de gestão de clientes

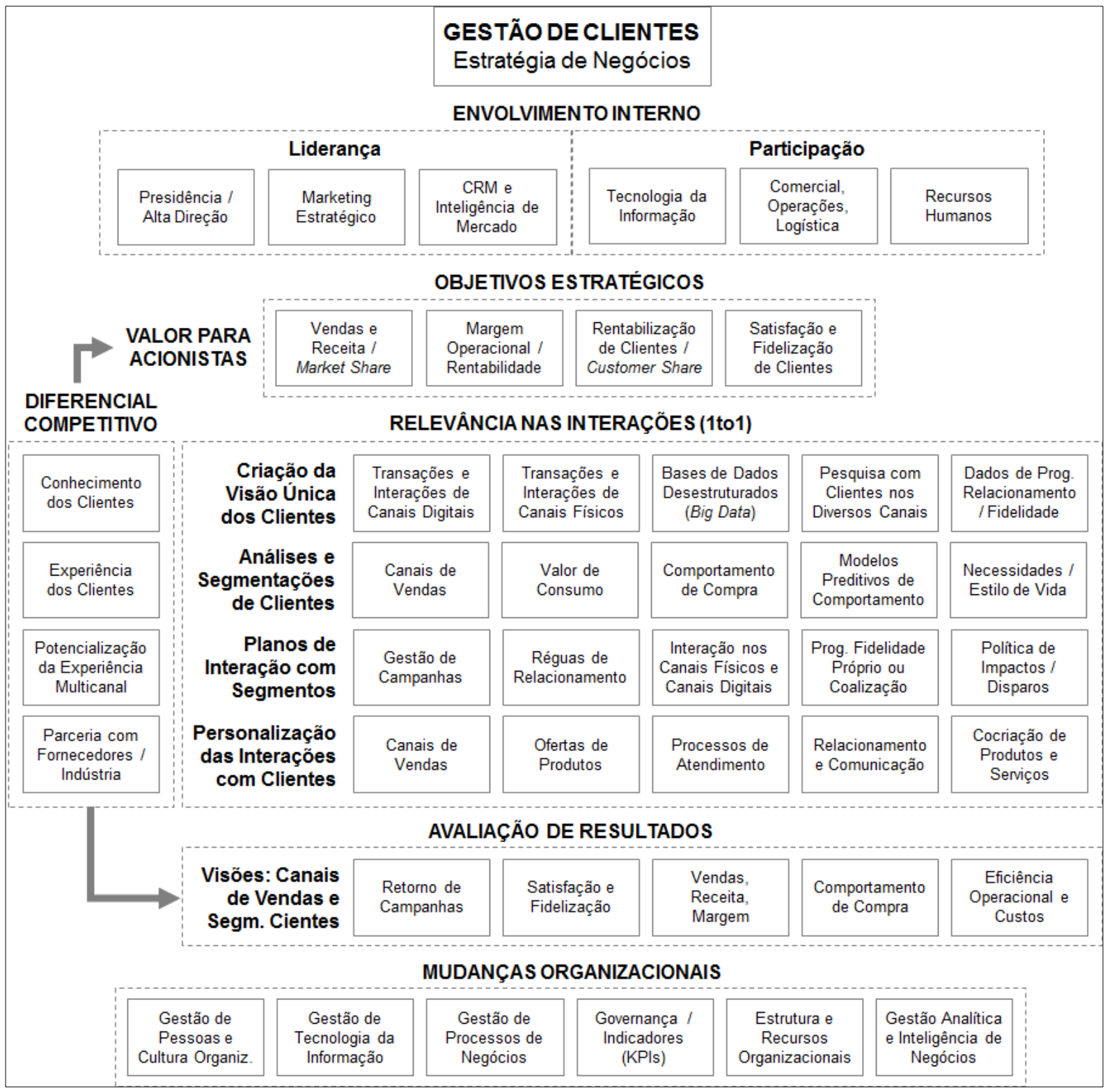

Fonte: Elaborado pelo autor. 


\section{CONSIDERAÇÕES FINAIS}

Como visto, o varejo brasileiro está vivenciando um grande processo de transformação, pois constitui-se um cenário de alta competição e forte tendência de atuação multicanal, com surgimento de novas tecnologias e mudanças no comportamento dos consumidores. Neste cenário, conforme proposto no estudo, existe a oportunidade de criar diferenciais competitivos por meio da estratégia de gestão de clientes para organizações de qualquer segmento do varejo, assim como acontece em outros setores bastante competitivos e com baixa diferenciação.

Para aumentar as chances de sucesso na implementação dessa estratégia, deve-se seguir diretrizes que considerem as particularidades do setor varejista e as características próprias das organizações. A aplicação dos procedimentos de análise de conteúdo, sugeridos por Bardin (2009), sobre as entrevistas em profundidade com especialistas em varejo, precedida do relato da experiência prática e levantamento do referencial teórico, permitiu fazer interpretações e inferências a respeito da implementação da estratégia de gestão de clientes no varejo multicanal.

A análise progressiva do documento, preparado a partir das respostas, culminou nos sistemas de categorias relativos a Varejo Multicanal e Omnichannel, e Processos de Gestão de Clientes. As similaridades e diferenças foram avaliadas em 7 categorias temáticas, possibilitando ao autor o entendimento de principais desafios e oportunidades, bem como possibilitou a identificação e análise das diretrizes.

\subsection{Contribuições do Estudo}

Com base na análise dos resultados, foi possível consolidar as diretrizes para implementação da estratégia de gestão de clientes, atingindo, assim, os objetivos propostos para o trabalho e colaborando para a inovação de marketing e organizacional no setor de varejo brasileiro.

Como contribuição para a prática dos negócios, para facilitar a compreensão e utilização, as diretrizes identificadas foram consolidadas e detalhadas em categorias temáticas: 
- Desenvolvimento da Estratégia: estratégia e objetivos organizacionais, envolvimento das áreas na estratégia, mudanças e impactos na organização;

- Gestão do Conhecimento dos Clientes: estruturação da visão única de clientes, segmentação da base de consumidores;

- Gestão da Experiência dos Clientes: planos de interação com consumidores, programas de relacionamento / fidelidade, personalização de produtos, serviços e interações;

- Avaliação de Desempenho e Resultados: indicadores e avaliação de resultados, criação de valor para acionistas.

Como contribuição para a teoria, esta pesquisa elucidou alguns temas e conceitos poucos explorados na literatura acadêmica, como o varejo multicanal e omnichannel, e a aplicação da estratégia de gestão de clientes neste ambiente, abrindo espaço para o desenvolvimento de novos estudos.

O presente estudo também atendeu, em parte, a temas da lista prioritária de pesquisas acadêmicas de 2014-2016 do Marketing Science Institute (2015), estes incluem: o entendimento do comportamento e a experiência dos consumidores, o desenvolvimento de métodos analíticos de marketing e o reconhecimento de diferenças entre os consumidores.

\subsection{Limitações do Estudo}

A estratégia de pesquisa escolhida, qualitativa e exploratória, com coleta de dados por meio de entrevista em profundidade, proporciona a maior compreensão de um problema ou tema novo ou ainda pouco estudado antes da formulação de hipóteses para pesquisas descritivas ou causais. É o caso da aplicação da estratégia de gestão de clientes no varejo multicanal. Porém, como limitação metodológica, é uma pesquisa de cunho não conclusivo e sujeita à experiência e interpretações do pesquisador.

Os procedimentos de análise de conteúdo, que incluem contagens de indicadores nas respostas, são importantes para reduzir o grau de subjetividade, mas sem possibilidade de eliminá-lo. Portanto, para que esta análise seja conclusiva, são necessários estudos quantitativos posteriores para avaliar as hipóteses e resultados levantados. 
Outra limitação é a amostragem por conveniência com um grupo heterogêneo de executivos e consultores de diversos segmentos, em sua maioria localizados em São Paulo, e que traz uma visão mais generalista dos temas abordados, não sendo possível fazer análises de recortes. $\mathrm{O}$ tamanho da amostra (13 entrevistados) é outro fator limitante, pois não permite a extrapolação das informações e a execução de operações estatísticas mais complexas e conclusivas.

Em relação aos resultados obtidos, deve-se considerar também o momento em que a pesquisa foi realizada. O atual contexto econômico brasileiro, com forte recessão e impacto nas vendas do varejo, certamente influenciou as respostas dos entrevistados, especialmente na análise do cenário competitivo do varejo multicanal. A análise de resultados também se limita ao varejo multicanal, não devendo ser considerado para operações single channel.

\subsection{Recomendações de Pesquisas Futuras}

Partindo das reflexões e resultados obtidos no trabalho, conclui-se que novas pesquisas podem ser realizadas, no sentido de aprofundar temas e proposições identificados, avaliar a aplicação das diretrizes para implementação da estratégia, ou fazer recortes para delimitar e continuar os estudos.

Para continuidade da exploração dos temas, recomenda-se a realização de pesquisas qualitativas por regiões geográficas e com grupos mais homogêneos. Por exemplo, só com consultores ou só com executivos de determinados segmentos do varejo (moda, supermercados, livrarias, etc.), com possibilidade de aprofundar recortes específicos dentro das categorias temáticas definidas, como processos, tecnologia, conhecimento, experiência, etc.

Uma sugestão é avaliar separadamente os canais de vendas, pós-vendas e relacionamento no varejo multicanal. Temas emergentes, como big data, cocriação e programas de fidelização e coalização, também são boas opões para o desenvolvimento de uma pesquisa.

Para avaliação das hipóteses levantadas sobre varejo multicanal e omnichannel, processos de gestão de clientes, ou aplicabilidade das diretrizes identificadas e consolidadas, sugere-se a execução de pesquisas quantitativas e conclusivas, por intermédio de questionário estruturado 
e aplicado em amostra representativa, que permita análises estatísticas; podendo ser também realizada com grupos mais homogêneos e com recortes do estudo.

Outra possibilidade, é a verificação da aplicação das diretrizes diretamente nas organizações, por meio de pesquisa-ação em varejistas que querem adotar a estratégia de gestão de clientes, com acompanhamento durante e após a implementação. Ou por estudos de caso simples ou múltiplos, preferencialmente realizados nas organizações que foram citadas como referência ou detentoras de boas práticas no varejo multicanal, como Magazine Luíza, Grupo Pão de Açúcar, Livraria Saraiva e Natura Cosméticos.

Por fim, recomenda-se fazer pesquisas qualitativas exploratórias também com consumidores, para que haja um entendimento das diferentes percepções sobre o varejo multicanal, bem como se desenvolva uma compreensão acerca das expectativas, o que valoriza, o que deve ou não ser integrado, conflitos de canais, impactos sobre os hábitos de consumo, etc. Por exemplo, uma questão que foi colocada por um dos entrevistados, é se realmente é necessário ter preços e promoções integradas, ou se é possível ter uma política de precificação dinâmica conforme a região, categoria, dia da semana, horário, perfil, etc. 


\section{REFERÊNCIAS}

AAKER, D.; JOACHINESTHALER, E. Como construir marcas líderes. São Paulo: Futura, 2000 .

BALL, D. et al. The role of communication and trust in explaining customer loyalty: an Extension to the ECSI Model. European Journal of Marketing. Bradford, v. 38, n. 9/10, p. 1271-1293, 2004.

. Service personalization and loyalty. The Journal of Services Marketing. Santa Barbara, v. 20, n. 6, p. 391-403, 2006.

BARDIN, L. Análise de Conteúdo. 5. ed. Lisboa: Edições 70, 2009.

BARRETO, I. F. Avaliação de resultados de ações de marketing de relacionamento. São Paulo, 2007. Dissertação (Mestrado em Administração) - Programa de Pós-Graduação em Administração, Faculdade de Administração, Economia e Contabilidade da Universidade de São Paulo - USP.

BARRETO, I. F.; CRESCITELLI, E. Marketing de relacionamento: como implantar e avaliar resultados. São Paulo: Pearson, 2013.

. O futuro do marketing de relacionamento. Revista da ESPM. São Paulo, p. 96-101, 07-08/2008.

BERRY, L. Relationship marketing of services: growing interest, emerging perspectives. Journal of the Academy of Marketing Science. Miami, v. 23, n. 4, p. 236-245, fall 1995.

BOULDING W. et al. Customer relationship management roadmap. Journal of Marketing. [S.1.], v. 69, n. 4, p. 155-166, 10/2005.

BRASHEAR, T. G. et al. A profile of the internet shopper: evidence from six countries. Journal of Marketing Theory and Practice. Winter Park, v. 17, n. 3, p. 267-282, 2009. 
BRETZKE, M. Marketing de relacionamento e competição em tempo real com CRM. São Paulo: Atlas, 2000.

BRYNJOLFSSON, E. et al. Competing in the age of omnichannel retailing. Sloan Management Review. Boston, v. 54, n. 4, p. 23-29, summer 2013.

CHAN, J. O. Toward a unified view of customer relationship management. Journal of American Academy of Business. [S.1.], 2005.

COUGHLAN, A. T. et al. Canais de marketing e distribuição. Tradução: Lucia Simonini. 6. ed. Porto Alegre: Bookman, 2012.

DAY, G. A empresa orientada para o mercado. São Paulo: Artmed, 2001.

DIAS, S. W. O desafio do varejo multicanal: comportamento free-riding do consumidor. São Paulo, 2014. Tese (Doutorado em Economia) - Programa de Pós-Graduação em Administração, Faculdade de Administração, Economia e Contabilidade da Universidade de São Paulo - USP.

GORDON, I. H. Relationship marketing: new strategies, techniques and technologies to win the customer you want and feet them forever. Toronto: John Wiley \& Sons Canada, 1998.

GUMMENSSON, E. Marketing de relacionamento total: gerenciamento de marketing, estratégia de relacionamento e abordagens de CRM para a economia de rede. Porto Alegre: Bookman, 2005.

HARDGRAVE, B. Omnichannel retailing. RFID Journal. [S.1.], v. 9, n. 6, p. 38-38, 11$12 / 2012$.

JAYACHANDRAN, S. et al. The role of relational information processes and technology use in customer relationship management. Journal of Marketing. [S.1.], 2005.

JOHNSON, M. D.; SELNES, F. Customer portfolio management: toward a dynamic theory of exchange relationships. Journal of Marketing. [S.1.], 2004. 
KHAUAJA, Daniela. Gestão de marcas na estratégia de internacionalização de empresas: estudo com franqueadoras brasileiras. São Paulo, 2009. Tese (Doutorado em Administração) Programa de Pós-Graduação em Administração, Faculdade de Administração, Economia e Contabilidade da Universidade de São Paulo - USP.

KIM, W. C.; MAUBORGNE, R. Blue ocean strategy. Harvard Business Review. Massachusetts, p. 76-84, 10/2004.

A estratégia do oceano azul: como criar novos mercados e tornar a concorrência irrelevante. Rio de Janeiro: Elsevier, 2005.

KOTLER, P.; ARMSTRONG, G.. Princípios de marketing. 7. ed. Rio de Janeiro: LTC, 1999.

KOTLER, P.; KELLER, K. Administração de marketing. 14. Ed. São Paulo: Pearson, 2012.

LEGATT, H. Have you met the omnichannel shopper? Biz Report: E-commerce. [S.1.], 23/10/2009.

LEVY, M.; WEITZ, B. Administração de varejo. São Paulo: Editora Atlas, 2000.

MANUAL DE OSLO. Proposta de diretrizes para coleta e interpretação de dados sobre inovação tecnológica. [S.1.]: OCDE, 2005. Disponível em: www.finep.org.br. Acessado em: $04 / 2014$.

FACULDADE DE ECONOMIA, ADMINISTRAÇÃO E CONTABILIDADE DA UNIVERSIDADE DE SÃO PAULO. Comissão de Pós-graduação. Manual para Formatação e edição de Dissertações e Teses. São Paulo, 2008.

MARKETING SCIENCE INSTITUTE - MSI. 2014-2016 Research Priorities. Disponível em: http://www.msi.org/research/2014-2016-research-priorities/. Acessado em: 06/2015.

MARTIN, R. The big idea: the age of customer capitalism. Harvard Business Review. Massachusetts, 01-02/2010. 
MARTINS, G. A.; THEÓPHILO, C. R. Metodologia da investigação científica para ciências sociais aplicadas. 2. ed. São Paulo: Atlas, 2009.

MATTAR, F. N. Administração de varejo. Rio de Janeiro: Elsevier, 2011.

MCKENNA, R. Marketing de relacionamento: estratégias bem-sucedidas para a era do cliente. Rio de Janeiro: Campus, 1992.

OGDEN, J. R.; CRESCITELLI, E. Comunicação integrada de marketing: conceitos, técnicas e práticas. 2. Ed. São Paulo: Pearson: 2007.

PARENTE, J. Varejo no Brasil. São Paulo: Atlas, 2010.

PAYNE, A.; FROW P. A strategic framework for CRM. Journal of Marketing. [S.1.], v. 69, n. 4, p. 167-176, 10/2005.

Customer relationship management: from strategy to implementation. Journal of Marketing Management. [S.1.], 2006.

PEPPERS, D.; ROGERS, M.; DORF, B. Marketing One-to-One. São Paulo: Makron, 2001.

PEPPERS, D.; ROGERS, M. The One-to-One Future. Nova York: Doubleday / Currency, 1993.

. CRM Series Marketing 1to1: guia executivo para entender e implantar estratégias de customer relationship management. São Paulo: Makron Books, 2004.

Descarte velhas regras, adote novas leis. São Paulo: Editora Globo, 2008.

PETER, J. P.; CHURCHILL JR, G. A. Marketing: criando valor para os clientes. 2. ed. São Paulo: Saraiva, 2000.

PORTER, M. E. Vantagem competitiva. 16. ed. Rio de Janeiro: Editora Campus, 1989. 
REGO, B. B. Criação de valor para o cliente: um estudo exploratório sobre programas de Key Account Management (KAM). São Paulo, 2016. Tese (Doutorado em Administração) Programa de Pós-Graduação em Administração, Faculdade de Administração, Economia e Contabilidade da Universidade de São Paulo - USP.

REICHHELD, F. F. A estratégia da lealdade: a força invisível que mantém clientes e funcionários e sustenta crescimento, lucros e valor. Rio de Janeiro: Editora Campus, 1996.

The loyalty effect. Harvard Business Review. Massachusetts, 1996.

REINARTZ, W. et al. The customer relationship management process: its measurement and impact on performance. Journal of Marketing Research. [S.1.], 2004.

RIGBY, D. The future of shopping. Harvard Business Review. Massachusetts, p. 65-76, $12 / 2011$

ROCHA, T.; VELOSO, A. A hora da recompensa: como obter sucesso através de programas de fidelização. São Paulo: M. Cobra, 1999.

RUST R. T. et al. Return on marketing: using customer equity to focus marketing strategy. Journal of Marketing. [S.1.], 2004.

RYALS L. Making customer relationship management work: the measurement and profitable management of customer relationships. Journal of Marketing. [S.1.], 2005.

SELLTIZ, C. et al. Métodos de pesquisa nas relações sociais. São Paulo: EPU, 1975.

SHANKAR, V. et al. Customer satisfaction and loyalty in on-line and off-line environments. International Journal of Research in Marketing. [S.1.], v. 20, n. 2, p. 153-175, 2003.

SHARLANOVA, V. Experiential Learning. Trakia Journal of Sciences, v. 2, n. 4, p. 36-39, 2004 
SHETH, J. N. The future of relationship marketing. The Journal of Services Marketing. Santa Barbara, v. 16, n. 7, p. 590-592, 2002.

SOUZA, M. G.; SERRENTINO, A. Multivarejo: a próxima economia. São Paulo: Makron Books, 2002.

SRINIVASAN, S. S. et al. Customer loyalty in e-commerce: an exploration of its antecedents and consequences. Journal of Retailing. [S.1.], v. 78, p. 41-50, spring 2002.

THOMA, C. The omnichannel shopper: anytime, anyplace, anywhere. Retail On-line Integration. [S.1.], 23/12/2010.

TONG, C. et al. The influences of service personalization, customer satisfaction and switching costs on e-loyalty. International Journal of Economics and Finance. Toronto, v. 4, n. 3, p. 105-114, 2012.

VAN BALL, S.; DACH, C. Free-riding and customer retention across retailer's channels. Journal of Interactive Marketing. New York, p. 75-85, spring 2005.

VERHOEF, P. C.; LEEFLANG, P. S. H. Understanding the marketing department's influence within the firm. Journal of Marketing. [S.1.], v. 73, p. 14-37, 2009.

VARGO S. L.; LUSCH R. F. Evolving to a new dominant logic for marketing. Journal of Marketing. [S.1.], 2004.

VAVRA, T. G. Marketing de relacionamento: aftermarketing. São Paulo: Atlas, 1993.

VESEL, P.; ZABKAR, V. Relationship quality evaluation in retailers' relationships with consumers. European Journal of Marketing. Bradford, v. 44, n. 9/10, p. 1334-1365, 2010.

WILDING, R. Multichannel or omnichannel? Logistics \& Transport Focus. [S.1.], v. 15, n. 10, p. 44-44, 12/2013.

YIN, R. K. Estudo de caso: planejamento e métodos. 2. ed. Porto Alegre: Bookman, 2001. 
YU, U. et al. Exploring perceived channel price, quality and value as antecedents of channel choice and usage in multichannel shopping. Journal of Marketing Channel. New York, v. 18, p. 79-102, 2011.

ZEITHAML, V. A. et al. The behavioral consequences of service quality. Journal of Marketing. Nova York, v. 60, n. 2, p. 31-46, 1996.

ZEITHAML, V. A.; BITNER, M. J. Marketing de serviços: a empresa com foco no cliente. 2. ed. Poroto Alegre: Bookman, 2003. 


\section{APÊNDICES}

\section{Apêndice A - Roteiro de Entrevista em Profundidade}

\section{Dados da Entrevista e Entrevistado}

- Data da Entrevista; Hora de Início e Fim;

- Meio de Entrevista; Local da Entrevista;

- Nome do Entrevistado; Cargo e Reporte; Função e Responsabilidades;

- Nome da Organização; Segmentos de Atuação; Linhas de Produto;

- Breve resumo da experiência e tempo em varejo e gestão de clientes (CRM).

\section{Preliminares da Entrevista}

- "Quebra-gelo", agradecimento e apresentação dos antecedentes do autor e mestrado;

- Breve explanação sobre os objetivos e motivações do projeto de pesquisa;

- Explicação sobre a escolha dos entrevistados e processo de pesquisa de campo;

- Alinhamento do tempo de entrevista e autorização para gravação da conversa;

- Visão do profissional atuante no setor, pensando nas empresas e projetos que participa ou participou pela ótica do varejista (não da indústria de bens), de qualquer segmento de varejo, considerando as principais organizações brasileiras (médio e grande porte);

- Alinhamento de principais conceitos abordados, por meio de apresentação de "fichas" com breve descrição dos temas (unidades de pesquisa);

- Rodízio entre os temas de pesquisa nas diferentes entrevistas, para evitar viés de cansaço.

\section{Parte 1 - Varejo Multicanal e Omnichannel}

1. Qual o seu entendimento sobre o cenário competitivo atual do varejo brasileiro? Quais os principais desafios, ameaças e oportunidades para as organizações do setor?

2. Quais as principais mudanças no comportamento dos consumidores nos últimos anos? Como estas mudanças afetam a forma de atuação das organizações do setor?

3. Qual seu entendimento sobre varejo multicanal? Quais os principais canais de vendas, pósvendas e comunicação, físicos e digitais, utilizados pelos varejistas?

4. Quais as principais tendências do varejo multicanal? Quais são os principais desafios, ameaças e oportunidades para as organizações de varejo que atuam neste modelo? 
5. Qual estágio de preparação das organizações de varejo para competir neste ambiente? Quais as principais dificuldades e fortalezas? Existem conflitos de canais?

6. As empresas estão conseguindo proporcionar a experiência omnichannel? Em que nível? (informações, serviços, comunicação, preços, produtos, estoques, etc.)

7. Quais os principais casos de sucesso de varejistas que atuam no modelo multicanal?

\section{Parte 2 - Gestão de Clientes: Desenvolvimento da Estratégia}

1. Como avalia a gestão de clientes (CRM) como estratégia para diferenciar a organização de varejo multicanal no cenário competitivo atual?

2. Quais seriam os principais desafios e objetivos organizacionais que uma estratégia de gestão de clientes poderia suprir ou contribuir, pensando em um varejista multicanal?

3. Como a estratégia de gestão de clientes poderia estar alinhada a propósitos, diretrizes, objetivos e indicadores de performance $(K P I s)$ corporativos?

4. Como deveria ser o envolvimento da alta direção e das diversas áreas da organização na estratégia de gestão de clientes (marketing, comercial, operações, etc.)?

5. Quais seriam as principais áreas envolvidas? Como a estratégia de gestão de clientes poderia estar alinhada aos planos estratégicos e táticos da organização?

6. Como a estratégia de gestão de clientes poderia impactar as decisões da organização (estrutura, processos, tecnologia, pessoas, governança, cultura, comunicação, etc.)?

\section{Parte 3 - Gestão de Clientes: Gestão da Informação / Conhecimento ( 10')}

1. Quais as implicações do varejo multicanal e omnichannel nos processos de coleta e armazenamento de dados, e criação e disponibilidade de visão única do cliente?

2. Quais as implicações do varejo multicanal e omnichannel nos processos de análise e $\underline{\text { segmentação da base de clientes, }}$ por valor, comportamento e necessidades?

3. Quais as implicações do varejo multicanal e omnichannel nos processos de pesquisas qualitativas e quantitativas com clientes (necessidades, satisfação, opinião, etc.)?

4. Quais os principais processos e tecnologias envolvidas para gestão da informação?

\section{Parte 4 - Gestão de Clientes: Criação de Valor / Experiência ( 15')}

1. Quais as implicações do varejo multicanal e omnichannel nos processos de venda, pós-venda e relacionamento com clientes, considerando diferentes segmentos?

2. Quais as implicações do varejo multicanal e omnichannel nos processos de interação com diferentes segmentos de clientes nos diversos pontos de contato? 
3. Quais as implicações do varejo multicanal e omnichannel nos processos de gestão de campanhas de relacionamento (planejamento, execução e avaliação)?

4. Quais as implicações do varejo multicanal e omnichannel nos processos de elaboração e gestão de programas de relacionamento / fidelidade?

5. Quais as implicações do varejo multicanal e omnichannel nos processos de criação de produtos e serviços customizados / personalizados?

6. Quais as implicações do varejo multicanal e omnichannel nos processos de coleta de feedback, entendimento e atendimento de necessidades?

7. Quais os principais processos e tecnologias envolvidas para criação de valor?

\section{Parte 6 - Processos de Avaliação de Desempenho ( 5' $\left.^{\prime}\right)$}

1. Quais as implicações do varejo multicanal e omnichannel nos processos de medição e avaliação de desempenho da estratégia de gestão de clientes?

2. Quais as implicações do varejo multicanal e omnichannel no alinhamento de métricas e

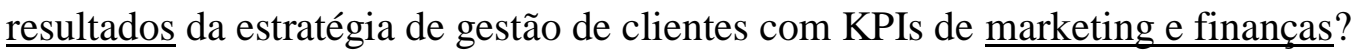

3. Qual o impacto da estratégia de gestão de clientes na criação de valor para os acionistas no curto, médio e longo prazos, considerando o varejo multicanal e omnichannel?

4. Quais as oportunidades de criação de valor junto às indústrias de bens de consumo por meio da estratégia de gestão de clientes, no ambiente multicanal e omnichannel?

\section{Encerramento da Entrevista}

- Agradecimento ao entrevistado e reforço de que as informações não serão identificadas de forma individual e serão tabuladas e analisadas para fins acadêmicos;

- Solicitar permissão para divulgação do nome / cargo do entrevistado e organização em que trabalha, sem citar as respostas nominalmente;

- Informar que o autor irá enviar uma cópia digital da dissertação após a finalização da pesquisa e avaliação da banca de avaliação;

- Combinar que o entrevistador pode contatá-lo em caso de dúvidas ou complemento, e também fica à disposição para qualquer comentário após esta entrevista;

- Pedir indicação de pessoas para entrevistar, se houver necessidade. 


\section{Apêndice B - Fichas com Descrição dos Temas de Pesquisa}

\section{Varejo Multicanal}

Arranjo do setor varejista para comunicação, vendas e pós-vendas (entrega, atendimento e relacionamento), por meio de múltiplos canais físicos (off-line) e digitais (on-line), que foram criados ou aprimorados pela evolução tecnológica. A expectativa é que os canais sejam complementares e estejam integrados para melhor experiência e maior satisfação do consumidor, possibilitando aumento de consumo e maior frequência de compra. A diferença entre varejo multicanal e omnichannel está na integração deste último.

\section{Consumidor Omnichannel}

A evolução do varejo multicanal, das mídias digitais e dos dispositivos móveis propiciou a ascensão de um novo perfil de consumidor, assim classificado como omnichannel. Este consumidor busca todas as formas e canais de comunicação, compra, atendimento e engajamento com a marca, permanecendo sempre bem informado e conectado. Ele escolhe de forma mais criteriosa os bens que adquire, pode utilizar vários canais simultaneamente e exige experiência de consumo e relacionamento de fato multicanal e integrado.

\section{Gestão de Clientes}

A gestão do relacionamento com clientes surge como uma estratégia para as organizações obterem vantagem competitiva sobre os concorrentes em ambiente de alta competividade e baixa diferenciação, por meio do relacionamento profundo com os principais clientes e da entrega de produtos e serviços mais qualificados. Nesse sentido, a referida estratégia está baseada no maior conhecimento e entendimento do comportamento e necessidades dos clientes, o que permite a entrega de interações e experiências mais relevantes e personalizadas. Dessa forma, é constituída uma relação de aprendizado de longo prazo entre a organização e seus melhores clientes. Como resultado, espera-se atrair novos clientes e obter maior satisfação, engajamento, fidelidade, rentabilidade e participação no consumo dos clientes atuais. 
